Andrews University

Digital Commons @ Andrews University

2008

\title{
A Friendship Evangelism Seminar for the Bladensburg Seventh- day Adventist Church
}

Marcellus Tyrone Robinson

Andrews University

Follow this and additional works at: https://digitalcommons.andrews.edu/dmin

Part of the Practical Theology Commons

\section{Recommended Citation}

Robinson, Marcellus Tyrone, "A Friendship Evangelism Seminar for the Bladensburg Seventh-day Adventist Church" (2008). Professional Dissertations DMin. 658.

https:dx.doi.org/10.32597/dmin/658

https://digitalcommons.andrews.edu/dmin/658

This Project Report is brought to you for free and open access by the Graduate Research at Digital Commons @ Andrews University. It has been accepted for inclusion in Professional Dissertations DMin by an authorized administrator of Digital Commons @ Andrews University. For more information, please contact repository@andrews.edu. 


\begin{abstract}
A FRIENDSHIP EVANGELISM SEMINAR FOR THE BLADENSBURG SEVENTH-DAY ADVENTIST CHURCH
\end{abstract}

by

Marcellus Tyrone Robinson

Adviser: Clifford Jones 


\section{ABSTRACT OF GRADUATE STUDENT RESEARCH}

Dissertation

Andrews University

Seventh-day Adventist Theological Seminary

\section{Title: A FRIENDSHIP EVANGELISM SEMINAR FOR THE BLADENSBURG SEVENTH-DAY ADVENTIST CHURCH}

Name of researcher: Marcellus Tyrone Robinson

Name and degree of faculty adviser: Clifford Jones, Ph.D.

Date completed: April 2008

Problem

Members of the Bladensburg Seventh-day Adventist Church expressed a desire establish closer bonds within the congregation and community. The lack of close friendships within the church fellowship led to several members transferring to other area churches. Later, an interest survey revealed the congregation wanted to participate in friendship evangelism. In response to the desire of members to form closer friendships and to engage in friendship evangelism, the purpose of this study is to develop a seminar of friendship evangelism for the Bladensburg Seventh-day Adventist Church that will enable members to identify, understand, and form friendships within the church fellowship while leading others to a personal relationship with Christ in a natural style. 


\section{Method}

The seminar, Climbing Friendship Mountain, was designed over a year and implemented in a six week period to teach participants how to identify, understand, and form friendships. The seminar consisted of the main components, classroom instruction and field work experience. The classroom instruction taught the participants principles and concepts of friendship evangelism. The purpose of the field work component was to provide the participants with an opportunity to practice the techniques and principles learned in the classroom.

\section{Results}

Participants who completed the seminar received a certificate. Participants formed new friendships within the church fellowship and with other non-believers. Some even successfully led friends and relatives to the faith, which resulted in baptism.

\section{Conclusions}

The project exposed the participants to the conscious reality that exists each day to form a friendship and share Christ with a friend. The positive evaluations received. The old friendships developed, and new friendship circles formed. Participants used their influence to secure opportunities for the seminar to be shared at four elementary schools, and three local churches. The fact that several participants were able to lead a friend to Christ and eventually become a baptized member of the local church affirms the contribution of the Climbing Friendship Mountain Seminar program and the validity of the project. 
Andrews University

Seventh-day Adventist Theological Seminary

A FRIENDSHIP EVANGELISM SEMINAR FOR THE BLADENSBURG SEVENTH-DAY ADVENTIST CHURCH

\author{
A Dissertation \\ Presented in Partial Fulfillment \\ of the Requirements for the Degree \\ Doctor of Ministry
}

by

Marcellus Tyrone Robinson

April 2008 
(C) Copyrighted by Marcellus T. Robinson 2008

All Rights Reserved 


\section{A FRIENDSHIP EVANGELISM SEMINAR FOR THE BLADENSBURG}

\section{SEVENTH-DAY ADVENTIST CHURCH}

A dissertation

presented in partial fulfillment

of the requirements for the degree

Doctor of Ministry

by

Marcellus T. Robinson

APPROVAL BY COMMITTEE:

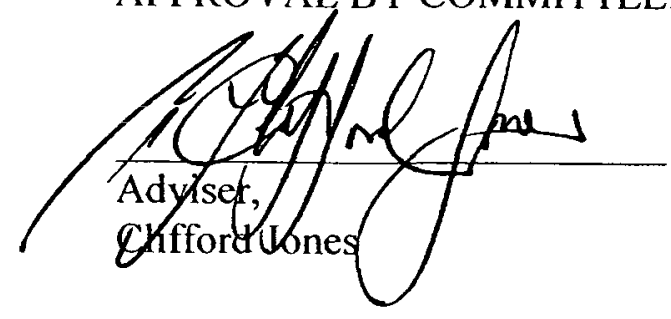

arcardo Qunton

Ricardo Norton

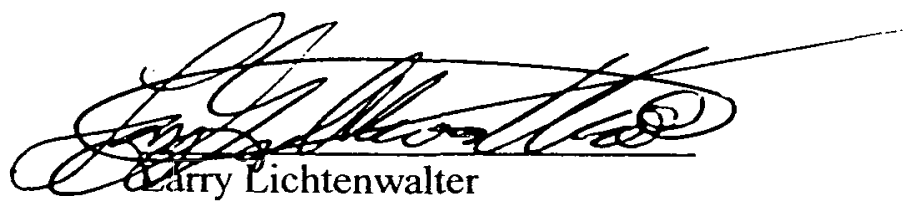

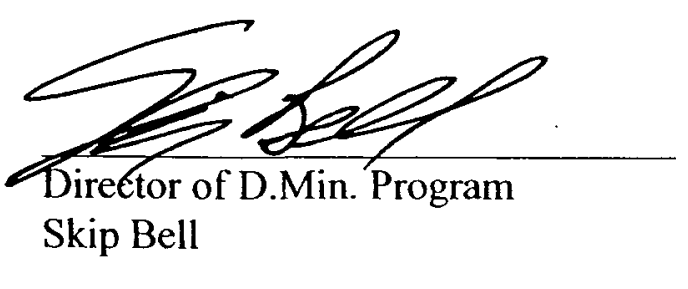

Denis Fortin

Dean, SDA Theological Seminary

Denis Fortin 


\section{DEDICATION}

To my wife Maryann, our daughters Marquita and Marcia, our parents William and Thelma Robinson and Shadrach and Geneva Lewis for their support. Their love and encouragement were a constant source of strength for me during my time of study. 
TABLE OF CONTENTS

ACKNOWLEDGMENTS

vii

\section{Chapter}

1. INTRODUCTION $\ldots \ldots \ldots \ldots \ldots \ldots \ldots \ldots \ldots \ldots \ldots \ldots$

Purpose of Dissertation. . . . . . . . . . . . . . . .

Statement of Purpose . . . . . . . . . . . . . . . . . . . 1

Statement of Task...................... 2

Justification of the Project.................. 2

Description of the Project. ................... 3

Definition of Terms ..................... 4

2. THEOLOGICAL FOUNDATIONS FOR FRIENDSHIP EVANGELISM $\ldots \ldots \ldots \ldots \ldots \ldots \ldots \ldots \ldots \ldots \ldots \ldots$

Definitions of Evangelism ................... 6

Biblical Foundations for Evangelism. . . . . . . . . . . . $\quad 9$

Covenant Relationships ...................... 11

God's Relationship with Noah. ................ 12

God's Relationship with Abraham................ 15

God's Relationship with Moses................ 20

God's New Covenant Relationship ............... 25

Friendship Evangelism in the New Testament. . . . . . . $\quad 28$

The Need for Friendship Evangelism. . . . . . . . . . 30

The Advantages of Friendship Evangelism ......... $\quad 32$

The Role of Laity in Bringing People to Christ ........ 34

Clergy-Laity Dichotomy..................... 34

Biblical View of Laity .................... $\quad 36$

Priesthood of All Believers ................. $\quad 37$

Ellen G. White and the Role of Laity ............ $\quad 38$

Lay Participation in the Great Commission......... 39

Laity Involvement in Friendship Evangelism ........ $\quad 39$

The Biblical Role of the Pastor .................. . 45

Pastoral Leadership ...................... 45 
The Equipping Role of the Pastor ............ $\quad 50$

Summary .......................... 52

\section{REVIEW OF FRIENDSHIP WITNESSING THROUGH} RELATIONSHIPS ...................... 54

Current Friendship Evangelism Programs. ........... 54

ACN Presents Friendship Evangelism.............. 54

Background Information . . . . . . . . . . . . 54

Program Content ................... 55

Evaluation....................... 56

Becoming a Contagious Christian. ............. 57

Background Information .............. 57

Program Content .................... 58

Evaluation ........................ 59

Making Friends for God $\ldots \ldots \ldots \ldots \ldots \ldots \ldots .60$

Background Information ............... 60

Program Content ..................... $\quad 60$

Evaluation ......................... 61

The Caring Evangelism Course. . . . . . . . . . . . . $\quad 62$

Background Information ................ 62

Program Content ................... 63

Evaluation ........................ 65

Witnessing Through Your Relationships.......... 65

Background Information . . . . . . . . . . . $\quad 65$

Program Content ...................... 66

Evaluation ............................ 67

Friend2Friend ........................... 68

Background Information . . . . . . . . . . . 68

Program Content ..................... 69

Evaluation ......................... 70

Summary $\ldots \ldots \ldots \ldots \ldots \ldots \ldots \ldots \ldots \ldots \ldots \ldots$

4. DESIGN AND IMPLEMENTATION OF THE PROJECT . . . 74

Organization of the Seminar ................. 74

Contextual Background. . . . . . . . . . ........ 74

Friendship Evangelism Seminar Background. . . . . . $\quad 78$

Friendship Evangelism Seminar Design. . . . . . . . $\quad 79$

Climbing Friendship Mountain. ................. $\quad 79$

Seminar Objectives .................... $\quad 80$

Course Outline $\ldots \ldots \ldots \ldots \ldots \ldots \ldots \ldots \ldots . \quad 80$

Enrollment of Participants ................ 83

Registration for the Seminar ............. 83

Consent to Participate in the Seminar .......... $\quad 84$

Participation in the Seminar. . . . . . . . . . . $\quad 84$ 
Classroom Instruction. . . . . . . . . . . . . . . $\quad 85$

Field Work ....................... 86

Evaluation of the Project. ............... 87

5. SUMMARY AND CONCLUSIONS. ............. 91

Summary $\ldots \ldots \ldots \ldots \ldots \ldots \ldots \ldots \ldots \ldots \ldots, 91$

Conclusions .......................... 94

Recommendations ...................... 95

Personal Reflection ..................... 97

Appendix

A. EXAMPLES OF PERSONAL EVANGELISM IN THE NEW TESTAMENT ....................... 100

B. A PARTIAL LIST OF FRIENDSHIPS IN THE BIBLE. . . . . 104

C. INTEREST SURVEY AND RESULTS. . . . . . . . . . 106

D. PERSONAL COMMITMENT CONTRACT.......... 112

E. PRE-REGISTRATION FORM. . . . . . . . . . . . . . 114

F. STATEMENT OF CONSENT $\ldots \ldots \ldots \ldots \ldots \ldots \ldots \ldots, 116$

G. CLIMBING FRIENDSHIP MOUNTAIN SERMON AND SEMINAR OUTLINES . . . . . . . . . . . . 118

H. CLIMBING FRIENDSHIP MOUNTAIN SEMINAR EVALUATIONS . . ....................... 149

BIBLIOGRAPHY $\ldots \ldots \ldots \ldots \ldots \ldots \ldots \ldots \ldots \ldots \ldots \ldots \ldots \ldots \ldots$

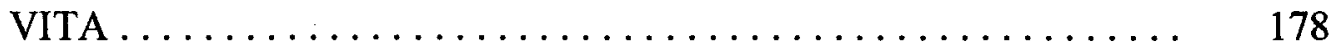




\section{ACKNOWLEDGMENTS}

This study could not have been completed without the help of the God of all Wisdom, and the guidance of supportive advisers, especially Dr. Clifford Jones. I am indebted to Dr. Gina Brown, Dr. Gene Donaldson, and Dr. Marcuis Harris, my mentors and friends, for their undaunted support; and the Bladensburg and Brinklow church families, for their patient understanding.

To the administrators, professors, and staff of the Andrew University Theological Seminary, especially Linda Bauer, my copy editor; to the administrators and workers of the Allegheny East and Lake Region Conferences; to the Climbing Friendship Mountain participants; to my wife, children, parents, brothers, sisters, and friends, I say thank you for all your support during this study. Above all, I say thanks be to God who specializes in making dreams come true and all things possible. 


\section{CHAPTER 1}

\section{INTRODUCTION}

\section{Purpose of Dissertation}

\section{Statement of the Problem}

One of the greatest needs in the local congregation is the need for close friendships. Individual case studies cite testimony of lonely people surrounded by uncaring members. These people want to be accepted, needed, heard, and loved. They believe the local church is cold, aloof, boring, condemning, unfriendly, and irrelevant to their social needs. ${ }^{1}$ Each year, Seventh-day Adventist members leave the fellowship of the local church because of the lack of friends within the congregation. About half of those who are baptized members in their mid-teens will drop out of the church by the time they are halfway through their $20 \mathrm{~s}^{2}$ Adding to the frustration level of Adventist members is the lack of knowledge and experience in forming new friendships within the local church and leading friends outside the church into a personal relationship with Christ. ${ }^{3}$

In March of 1997, several of the single adults (ages 17-35) expressed the need for

${ }^{1}$ Roger L. Dudley, Why Our Teenagers Leave the Church (Hagerstown, MD: Review and Herald Publishing Association, 2000), 60-64.

${ }^{2}$ Ibid., 60 .

${ }^{3}$ Ibid., 63. 
closer friendships within the Bladensburg Seventh-day Adventist Church (Bladensburg Church). Upon further investigation, the pastor discovered some of the single adults had transferred to other churches in the area seeking to establish these close bonds. In the fall of the same year, several members asked if the church could participate in another form of evangelism rather than hold a three week tent meeting or conduct a Revelation Seminar. An interest survey was conducted which revealed the desire of many of the members to learn friendship evangelism.

\section{Statement of the Task}

It was the purpose of this project to: (1) develop a seminar of friendship evangelism that would enable the members to identify, understand, and form friendships; (2) foster closer bonds within the congregation and the community; (3) lead a friend to a personal relationship with Christ; and then, (4) evaluate the results.

\section{Justification of the Project}

The Bladensburg Church is located in the township of Bladensburg, Maryland (one mile east of the northeast quadrant of the District of Columbia). Both the Bladensburg church (membership of 300) and community (population of 7,661) are composed mainly of single female adults (ages 17-36), predominately African American (yet representing a diverse population of several countries). The largest group of youth in the Bladensburg Church are children (ages 3-10). The Bladensburg Seventh-day Adventist Church has demonstrated that through friendships, people become members of the local congregation. On the other hand, the Bladensburg Seventh-day Adventist Church has discovered that one of the primary reasons that people leave the local church 
is the lack of friendships. A concept of friendship evangelism needs to be in place for the following reasons: (1) the local church membership needs to be stabilized through friendships in order to survive for future evangelism; (2) the local church members desire intimate friendships within the church fellowship, but do not know how to make friends;

(3) many members and leaders do not understand or know how to form friendships with non-members; (4) more members need to become actively involved in sharing Christ with friends; (5) many church members do not know or understand how to lead a friend to accept Christ, and (6) local church leaders who desire to train members in forming friendships need a resource manual for training and assistance.

\section{Description of the Project}

The theological foundations for a concept of friendship evangelism from the Bible, writings of Ellen G. White, and current literature were reviewed. Lay persons were surveyed from the Bladensburg Seventh-day Adventist Church. Members were identified who had an interest in making friends and leading their friends into a relationship with Christ.

A seminar was conducted with eleven hours of instruction. The seminar consisted of two sermons, classroom instruction and field work experience over six weeks. The classroom instruction included the following: (1) A Need for Friendship Evangelism; (2) Four Levels of Friendship Evangelism; (3) How to Make Check-Out Friends; (4) How to Make Choice Friends; (5) How to Establish Close Friends, and (6) How to Introduce

1'EEllen G. White (1827-1915). Cofounder of the SDA Church, writer, lecturer, and counselor of the church, who possessed what SDAs have accepted as the prophetic gift described in the Bible." Seventh-day Adventist Encyclopedia, 1976 ed., s.v. "White, Ellen Gould (Harmon)." 
People to Your Best Friend. Each session included lesson objectives, instruction, class participation, and summary. The participants engaged in field work assignments beginning with Lesson 3 .

The project was evaluated by surveying the participants after the training. Current pastors and past participants were informally interviewed. Conclusions, reflections, suggestions, and a summary of the project were compiled.

\section{Definition of Terms}

Allegheny East Conference (AEC): One of eight Regional Conferences that covers the territory of New Jersey, the eastern half of Pennsylvania, Delaware, Maryland, Washington, DC, and the eastern half of Virginia.

Administration: The administrative personnel (President, Secretary, and Treasurer) of a Seventh-day Adventist conference.

Best Friends: Jesus Christ along with a few close friends who share your most intimate secrets, thoughts, and emotions. Usually, they can be counted on one hand.

Bringing People to Faith: What is commonly called soul winning; the process of personal evangelism.

Candidate: A non-Seventh-day Adventist who is in the process of being brought to faith, or who has made a decision to be a part of the fellowship of a local church.

Check-Out Friend: A person that you meet briefly as you go through life's journey simply because of where you live, what you do, or where you go. The acquaintance could be a stranger, neighbor, co-worker, or relative.

Choice Friend: A person who shares your time mainly in common social activities or events.

Church: A local congregation, the Seventh-day Adventist church as a denomination, or Christianity as a religion.

Close Friend: A person who assists you in your crisis moments of life and with whom you develop an emotional bond which continues to develop with time.

Community of Faith: A local congregation. 
Evangelism: The communication of the gospel of Christ with the intent to convert a person to Christ.

Friendship Evangelism: A Christian sharing the gospel of Christ through a personal relationship with those whom one comes in contact with frequently. Also known as relational evangelism or relational outreach.

Interest: A non-Seventh-day Adventist who has displayed some indication of being brought to faith.

Laity: Members of the church who are not a part of the remunerated clergy. In certain specified instances it can refer to the entire people of God.

Personal Evangelism: The intentional encounter with a prospect, interest, or candidate, usually in a one-to-one context, for the purpose of bringing the individual to faith.

Prospect: A non-Seventh-day Adventist who has been approached for the purpose of being brought to faith and who has the potential to become an interest.

Public Evangelism: The planning, execution, and follow-up of a series of preaching or teaching meetings designed to bring people to faith in a non one-to-one context.

Regional Conference(s): The eight organized branches of the Seventh-day Adventist Church in North America administered by African-American leadership, primarily to serve a non-Caucasian constituency, and which cover a territory overlapping several states.

Seventh-day Adventist: The Seventh-day Adventist Christian denomination or a member thereof. 


\section{CHAPTER 2}

\section{THEOLOGICAL FOUNDATIONS FOR FRIENDSHIP EVANGELISM}

This chapter focuses on the theological foundations for evangelism in Scripture. The biblical material is examined for a better understanding of the mandate for bringing others to faith in Christ through friendship evangelism. A review of the biblical literature reveals how the covenant relationship between God and humanity is God's first action of friendship evangelism. The importance and advantages of friendship evangelism are highlighted and particular emphasis is given to the role of the laity in establishing friendly relationships with people to bring them to faith in Christ through friendship evangelism. The writings of Ellen $\mathrm{G}$. White are examined for additional perspectives regarding the role of the laity and pastors in establishing friendly relationships with people to bring them to faith in Christ through friendship evangelism. The literature of other Christian writers is referenced for additional insight regarding the role of the laity in friendship evangelism.

\section{Definitions of Evangelism}

The word evangelism is never used in the Bible. ${ }^{1}$ Evangelism is a peculiarly

${ }^{1}$ William J. McKay, Me, an Evangelist?: Every Christian's Guide to Caring Evangelism (St. Louis, MO: Stephen Ministries, 1992), 19. 
Christian concept. ${ }^{1}$ The Greek words behind the concept of evangelism are derived from the noun euangelion and its verbal cognate, euangelizo. ${ }^{2}$ Euangelion comes from two Greek words, eu, which means "good," and angellion, which means "message" or "news," literally translated "good news" or "gospel." Euangelizo means "to announce the good news," literally translated "evangelize."

Several authors have established additional definitions as well. Carlyle B. Hayes stated, "Evangelism means the proclamation of this good news, with the ultimate aim of its acceptance."

James I. Packer defined evangelism in the following words, "Evangelizing, therefore, is not simply a matter of teaching, and instructing, and imparting information at the mind.... Evangelism includes the endeavor to elicit a response to the truth taught. It is communication with a view to conversion. It is a matter of not merely informing, but also of inviting."

G. Michael Cocoris, after considering a variety of interpretations, concluded that "evangelism is communicating the gospel of Jesus Christ with the immediate intent of

${ }^{1}$ William Abraham, "A Theology of Evangelism: The Heart of the Matter," Interpretation 48 (1994): 118.

${ }^{2}$ Pedrito U. Maynard-Reid, Complete Evangelism: The Luke-Acts Model (Scottsdale, PA: Herald Press, 1997), 59.

${ }^{3}$ McKay, 5 .

${ }^{4}$ G. Michael Cocoris, Evangelism: A Biblical Approach (Chicago, IL: Moody Press, 1984), 12.

${ }^{5}$ Carlyle B. Haynes, Living Evangelism (Takoma Park, MD: Review and Herald Publishing Association, 1937), 33.

${ }^{6}$ James I. Packer, Evangelism and the Sovereignty of God (Chicago, IL: InterVarsity Press, 1961), 50. 
converting the hearer to faith in Christ, and with the ultimate intent of instructing the convert in the Word of God so that he can become a mature believer."1

The Lausanne Covenant, developed at the International Congress on World Evangelization, defined evangelism in these words, "To evangelize is to spread the good news that Jesus Christ died for our sins and was raised from the dead according to the scriptures, and that as reigning Lord He now offers the forgiveness of sins and the liberating gift of the Spirit to all who report and believe.... Evangelism itself is the proclamation of the historical, biblical Christ as Savior and Lord, with a view of persuading people to come to Him personally and so be reconciled to God."2

Terry Wardle summed up evangelism as, "Communicating the Good News of salvation to men and women everywhere, giving them a valid opportunity to receive Jesus Christ as Lord and Savior and to become faithful, responsible members of His church."3

Given these parameters it can be said that evangelism is the communication of the gospel with the intent to convert a person. It includes information about Christ (His life, death for sin and resurrection) and an invitation to trust Him. ${ }^{4}$ Evangelism involves more than making people Christians, it means making them disciples of Christ. According to Paul in Col 1:28, the ultimate goal of evangelism is for a believer to reach maturity in his

${ }^{1}$ Cocoris, 14.

${ }^{2} \mathrm{~J}$. D. Douglas, ed., Let the Earth Hear His Voice (Minneapolis, MN: World Wide Publications, 1.975), 4.

${ }^{3}$ Terry Wardle, One to One: A Practical Guide to Friendship Evangelism (Camp Hill, PA: Christian Publications, 1989), 8.

${ }^{4}$ Cocoris, 15 . 
or her personal, spiritual growth and service for Christ. ${ }^{1}$ The source of power that works in Christians to announce Christ to people as they reach spiritual maturity is the Holy Spirit (Acts 1:8). Evangelism is the outworking of the love of God in a fallen world. God is involved in it. God the Father got involved when He sent His only Son (John 3:16). Jesus Christ deemed it such a priority that $\mathrm{He}$ made it the subject of His last command to His disciples (Matt 28:19, 20). The Holy Spirit was specifically given to equip the church for bearing witness (Acts 1:8).

The chief business of the church is evangelism. The church is in existence for the purpose of carrying the gospel of Christ to those who do not know Him. Everything else in the church, no matter how important it may be, must take second place to this work. Every member of the community of faith, whether clergy or laity, bears a responsibility to God of carrying out the divine commission to "go" and "preach" to all segments of society in the world (Matt 28:19, 20). The whole church must engage in the initiative of sharing the "good news" and intentionally persuading those who have not embraced the "good news" about the reality of salvation through Jesus Christ.

\section{Biblical Foundations for Evangelism}

Evangelism has always been one of the central themes of the Bible. After Adam and Eve sinned, the Bible is clear that God took the initiative in seeking reconciliation with humanity. When the first couple hid from God in fear, guilt, and shame with marks of sin already within and around them, God approached them with the searching love call, "Where art thou?" (Gen 3:9). These first words of God to fallen humanity are the marks

${ }^{1}$ Ibid., 14. 
of grace. ${ }^{1}$ God was calling sinners back to a redeeming relationship. Then God first told the good news to Adam when He announced that the "seed of the woman" should bruise the serpent's head (Gen 3:15). Thus the first messianic promise in the Bible speaks of One who will effectively break the power of Satan. This message of the Redeemer is evangelism. This promise gave Adam and Eve hope in their desperation. This hope is built on the promise of a renewed relationship with God, one of grace, mercy, forgiveness, salvation, pardon, and power. ${ }^{2}$ The initial reaching out on the part of God toward Adam and Eve is the beginning of the redemptive covenant relationship between God and humanity. The unveiling of God's love in His covenant relationship to Adam and Eve did not end in Eden. Down to our time, the Lord continues to reach out to everyone. The apostle Paul declares in 2 Pet 3:9: "The Lord is not slack concerning his promise, as some men count slackness; but is longsuffering to us-ward, not willing that any should perish, but that all should come to repentance." ${ }^{3}$ Keith Intrater describes how evangelism is revealed in covenant relationships:

Evangelism is an act of love in the sense that it seeks to restore a relationship that is broken. An unsaved person is alienated from his relationship with God. Evangelism confronts a person with the blood covenant offered by Jesus. He is invited by this loving confrontation to reenter a relationship with God and the other believers in the world. ... All of God's actions on earth are redemptive. God's method of redemption and restoring relationships is to make a covenant. God's operation in the earth are done through covenant. God's posture toward us is one of offering and keeping covenant. ... There is no reason for God to perform any action outside of covenant. A non-covenantal action would not serve to reestablish a committed relationship. If God operates outside of covenant, He nullifies His own purpose. A non-covenantal action

'Derek Kidner, Genesis (Downer's Grove, IL: InterVarsity Press, 1967), 70.

${ }^{2}$ Gerhard F. Hasel, Covenant in Blood (Mountain View, CA: Pacific Press Publishing, 1982), 15.

${ }^{3}$ All biblical references are taken from the King James Version unless otherwise specified. 
would be self-defeating and lack integrity. God never does so. ${ }^{1}$

\section{Covenant Relationships}

The covenant theme is one of the all-encompassing concepts that unifies the Old and New Testaments of the Bible. The good news of salvation is communicated to humanity through the covenant and sanctuary from God to humanity. The biblical covenant concept expresses an intimate relationship between God and humankind.

The standard expression in the Old Testament for the establishing or making of a covenant between God and humanity is the phrase "to make a covenant." The Hebrew phrase reads literally, "to cut a covenant. ${ }^{, 3}$ This expression appears in the Old Testament no less than eighty times. The more frequent and most significant usage of the "covenant," occurs in connection with the covenantal relationship between God and humanity ${ }^{4}$ In the divine-human relationship, covenant is a divinely initiated and sovereign-ordained phenomenon between God and humankind. God as superior Lord graciously discloses, confirms, and fulfills the covenant promise. Humankind as beneficiary of the divine covenant gifts freely accepts the enduring relationship and renders obedience to the divine obligations (commandments, statues, laws and

\footnotetext{
${ }^{1}$ Keith Intrater, Covenant Relationships (Shippensburg, PA: Destiny Images Publishers, 1989) 124-125.

${ }^{2}$ See Gen 15:18; Exod 24:8; Deut 4:23; 5:2; Jer 11:10; Ezek 34:25; etc.

${ }^{3}$ Richard Booker, The Miracle of the Scarlet Thread (Shippensburg, PA: Destiny Images Publishers, 1981), 26.

${ }^{4}$ Edward Heppenstall, Our Firm Foundation, 2 vols. (Washington, DC: Review and Herald Publishing Association, 1952), 1:446.
} 
ordinances) by the assisting and enabling grace provided by God. ${ }^{1}$ God uses covenant relationships as a means of evangelizing humankind through friendships. Through the covenant relationships with humanity, God initiates dialogue with humankind as a friend speaking to a friend. The Lord invites humanity into a restored friendship relationship. This friendship between God and humankind is sealed by the blood of Christ. By faith in Christ, humanity receives the daily benefits of salvation, support, protection, and guidance from God. Once God has befriended someone, the person is responsible for sharing the benefits of his or her growing friendship with God with others. These components of friendship evangelism are revealed in the covenant relationship between the Lord and Noah, Abraham, Moses, the prophets, and His people, Israel, in the Old Testament. Skip MacCarty states, "Whatever else may be said about the covenants, it can never be said that any covenant ever initiated by God was based on, or was an expression of, anything other than the everlasting gospel He ordained to be preached 'to every nation, tribe, language, and people' (Rev 14:6). This is a foundational, core truth that must be affirmed and constantly kept in mind in any study of covenants."2

\section{God's Relationship With Noah}

From Gen 3 through Gen 6:5, sin had corrupted God's perfect creation. ${ }^{3}$ Sin spread dramatically and produced an ever-widening chasm between God and humanity.

${ }^{1}$ Ibid., 1:439.

${ }^{2}$ Skip MacCarty, In Granite or Ingrained? (Berrien Springs, MI: Andrews University Press, 2007), 9.

${ }^{3}$ Larry Richards, Every Covenant and Promise in the Bible (Nashville, TN: Thomas Nelson Publishers, 1998), 11. 
Its disintegration had reached fantastic proportions by Noah's time. ${ }^{1}$ God described humankind's intent in Noah's day as being so bad that "every imagination of the thoughts of his heart was only evil continually" (Gen 6:5). God assessed the situation in a comprehensive way. The word imagination means "design," "purpose," or "intent." The word heart designated the seat of the thinking and reasoning powers and usually referred to the mind with all its faculties. Every purpose, intent, and design of the thoughts of humanity's inner life was only wicked continually.

God's reaction is clearly noticeable. First, He "repents" (Gen 6:6). This "repentance" is not identical with the repentance of humankind (1 Sam 15:29). ${ }^{2}$ The second reaction within God revealed by Gen 6:6 is sadness. God was "grieved" in His heart—deeply hurt by humanity's wickedness. This revelation of God depicts Him as a being whose heart can be pained by humanity's sin. God does not judge human sin in coldness of feelings or distance, but rather deals with sin in such a way that He will control it. God determined that the massive and sustained spread of sin needed to be checked. Total perversion of man's thoughts to the very core of His will and reasoning powers called for drastic action. God was moved to action. ${ }^{3}$

${ }^{1}$ Sin moves from disobedience (Gen 3:1-7) to murder (Gen 4:8) to reckless killing and titanic lust $(\mathrm{Gen} 4: 23,24)$ and on to total corruption and violence (Gen 6:1-12).

${ }^{2}$ The Hebrew language consistently employs a certain word in the Old Testament in referring to God's repentance-nicham. It does not connote a lack of foresight on God's part or any variableness in His nature or purpose. The word is employed simply to present the truth "that God, in consistency with his immutability, assumes a changed position in respect to changed man." "Genesis." Seventh-day Adventist Bible Commentary. Edited by F. D. Nichol. Hagerstown, MD: Review and Herald Publishing Association, 2002. 1:251.

${ }^{3}$ Watchman Nee, The Better Covenant (New York, NY: Christian Fellowship Publishers, 1982), 27. 
The noun "covenant" is found in the Bible for the first time in Gen 6:18. ${ }^{1}$ The speaker is God, and Noah is the one addressed. A divine decision had been made; God would virtually bring to an end the work He wrought in Creation in the form of a worldwide flood (Gen 6:7,13). Yet God remained committed to the world He had created. He had not forsaken those who had not forsaken him. So, God, in fulfilling His divine purpose, made a covenant as an expression of His relationship with Noah that is expressed in Gen 6:18. The divine, redemptive purpose of the covenant relationship that had been in operation since the fall (Gen 3:15) is here renewed by God taking the initiative: "But with thee will I establish my covenant" (Gen 6:18). The divine "I" of the covenant initiative is Noah's ground of security in the impending crisis. ${ }^{2}$ God establishes ${ }^{3}$ the covenant. The divine command "thou shall come into the ark" reveals that God's covenant with Noah stipulates an obligation. It is God's covenant, "my covenant," and Noah and his family were to be the recipients and the beneficiaries of the covenant blessing resulting. Noah's response to God's invitation to enter into a covenant with him by going into the ark demonstrates his faith and complete trust in God. ${ }^{4}$

In establishing His covenant (Gen 9:8-17) ${ }^{5}$ with Noah, God dispenses His bountiful grace and mercy. Noah and his family become the carriers of life for the future

${ }^{1}$ Richards, 18.

${ }^{2}$ Ibid., 13, 18.

${ }^{3}$ In Gen 6:18 the term used is to establish. A careful investigation of this term in connection with covenant-making reveals the significance of to "maintain" or "confirm." Compare Deut 9:5; 27:26; 1 Sam 15:11; 2 Sam 7:25; 2 Kgs 23:3, 24.

${ }^{4}$ Richards, 18.

${ }^{5}$ This covenant is the first and only one in the Bible totally universal in scope. It includes the animals as well as Noah and his family. 
of all humanity. Through them, also, all the blessings of life come to humankind (Gen 7:23). ${ }^{1}$ This covenant relationship includes the external, physical sign of a rainbow in the clouds that serves as a reminder to the Lord of His covenant never to destroy the earth again with a flood (Gen 9:12-16). ${ }^{2}$ Humanity's security in the present and assurance of salvation in the future arise out of God's grace and the divine action on behalf of humankind. God shows himself to be a merciful and a gracious God, steadfast in His love for humanity. ${ }^{3}$ The origin and initiation of the covenant relationship is fully grounded and secured in God. Humankind is the beneficiary of this relationship, demonstrating once again that salvation is from the Lord. God befriends Noah through His covenant relationship which results in the salvation of humanity. God's action of saving humanity through His covenant relationship with Noah can be viewed as friendship evangelism.

\section{God's Relationship with Abraham}

God's friendship with humankind is extended through His covenant relationship with Abraham over three stages. ${ }^{4}$ This divine covenant is a covenant of grace and

${ }^{1}$ The word "only remained" is the first explicit idea of the remnant in the Bible. It is important to recognize that also at the end of the world the remnant that will be saved will again be people who respond to God by faith and obedience. It will be a remnant that stands in the right relationship with God who walks with God (Rev 12:17).

${ }^{2}$ It confirms the covenant and assures humanity of protection. It imparts the knowledge that God has kept and will keep his promise to never again bring flood to destroy the earth. God's faithfulness to his promise should elicit in humankind faithfulness to God and serve as a potent deterrent to a life of sin.

${ }^{3}$ Richards, 18.

${ }^{4}$ Ibid., 31. The first is reported in Gen 12:1-3; the second in Gen 15:1-21; and the third in Gen 17:1-14. 
salvation. God initiated it out of His free love. ${ }^{1}$ He revealed himself to Abraham repeatedly as Yahweh. ${ }^{2}$ In Yahweh resides the initiative in both creation and salvation, and also the ultimate control over the present and the future. God's choice of Abraham was not based on any inherent superiority within him which called for a reward. God's choice of him was grounded in divine love, grace, and mercy (Deut 7:6-11). Indeed, Abraham's actions reveal his unworthiness as a covenant partner. ${ }^{3}$ The Lord initiates His friendship with Abraham in spite of Abraham's undesirable personal qualities.

During the first stage of the covenant, in Gen 12:1-3, we find a fivefold "I will" on the part of God, revealing the intensity and greatness of His commitment to Abraham. ${ }^{4}$ These "I will" promises that God made to Abraham are related to God's constant presence with His servant, assuring him that God would be a "shield" to him. God also gave a Messianic promise to be fulfilled through the seed of Abraham. He promised to make Abraham a great and mighty nation. God also promised to make the name of Abraham great. He promised to give him and his offspring a land of their own. Yet, Abraham received but a single, searching command, "Go forth" (Gen 12:1, NASB). Abraham obeyed by faith, according to Heb 11:8, not in order to bring about the blessing promised by God. His part was a response of faith that corresponded to the gracious relationship which God was about to establish with him. While Abraham is engaged in

${ }^{1}$ See Gen $12: 1,2 ; 15: 7,18 ; 17: 1,2,7$.

${ }^{2}$ The Hebrew word for a proper noun or personal name of God. The exact meaning of the name Yahweh cannot be easily established. But in Ex 3:14 God himself explains this name to mean "I AM THAT I AM." This unique phrase expresses the reality of God's unconditional existence and his sovereignty over past, present, and future.

${ }^{3}$ See Gen 12:10-20; 16:1-16; 20:1-18.

${ }^{4}$ Richards, 24-26. 
this covenant relationship with God, one observes constant growth and personal advancement in his spiritual development with God (Gen 18:22-33; 22:1-14). The Lord's friendship with Abraham grows stronger with faith experience.

In the second stage of the covenant-making process, recorded in Gen 15:1-21, God takes the initiative in reaffirming His covenant relationship with Abraham. Abraham is a hero of faith who is "the friend of God." "Abraham believed in the Lord" (Gen 15:6). What brought about this faith response in Abraham? It was brought about by "the Lord," who appeared to Abraham in a revelatory event in history (Gen 15:1). The Lord, or Yahweh, the God who guides human beings and who is the sovereign over history giving it direction, had come again to Abraham. So Abraham's faith was faith "in" a person, "the Lord." Thus his faith and trust were "in the Lord." Faith here means that Abraham fully and unconditionally accepted as sufficient the divine revelation in the form of the promise of a son. ${ }^{2}$ This faith is a response to a divine revelation that is propositional. It is a tangible promise to be fulfilled in the future. Faith in this instance, as always when it relates to true faith, is evoked by God. ${ }^{3}$

Righteousness is something that God declares to be "counted" or "reckoned" to Abraham, ${ }^{4}$ who has a right standing before God. Abraham's response of faith to God's word of promise causes God to reckon this faith to Abraham as righteousness. Abraham

${ }^{1} \mathrm{H}$. Clay Trumbull, The Blood Covenant (Kirkwood, MO: Impact Christian Books, 1975), 216-218. Cf. Heb 11:8-12; Rom 4; James 2:23.

${ }^{2}$ E. W. Kenyon, The Blood Covenant (Lynnwood, WA: Kenyon's Gospel Publishing Society, 1969), 17.

${ }^{3}$ Booker, 52 .

${ }^{4}$ Richards, 28. 
believed God's word that a "seed" would be provided from his own loins. He trusted that God would fulfill His promise. He simply trusted God. His implicit trust in God as a Person, and in His promise, reveals that the idea of righteousness in this particular passage is essentially a relational term. ${ }^{1}$ Righteousness, therefore, is reckoned to a person when a right faith relationship exists between the person and God. All the while, this faith relationship is God-produced and accepted by the person. In other words, being counted as righteous is not based on an act by a human being but rather upon faith evoked by God himself within that human being. The human dimension of faith, trust, and confidence in the promise of the Lord and the Lord himself means a submission of one's whole life, present and future, into God's hand. ${ }^{2}$ Genuine biblical faith becomes effective in lifestyle and attitudes. The Lord's friendship with Abraham reveals signs of growth as Abraham lives out the promises of the Lord.

In the final stage of the covenant-making process, recorded in Gen 17:1-14, when Abraham was ninety-nine years old, God reaffirms His covenant and announces to Abraham that it would be established with the birth of a son, Issac, to be born within a year (Gen 17:21). At this crucial point God introduces Himself to Abraham as "Almighty God" for whom nothing was impossible. ${ }^{3}$ God is truly an "Almighty God"4 who brings

${ }^{1}$ Trumbull, 220.

${ }^{2}$ Kenyon, 17.

${ }^{3}$ Ibid., 19.

${ }^{4}$ The designation "Almighty God" is the English of the Hebrew El-Shaddai. El is the generic Semitic name for deity and is used for the most part in the Old Testament as a synonym for Yahweh. Examples are found in Num 23:8, 19, 22, 23; 24:4, 8, 16, 23; Ps $16: 1 ; 17: 6 ; 85: 8$; Isa $40: 18 ; 42: 5$. The exact origin and meaning of the name Shaddai is not certain. This designation (or simply "Almighty") is found principally in Genesis and Job. Compare Isa 13:6; Joel 1:15. 
about the fulfillment of His covenant promises in His own time and without human-made attempts to help Him (Gen 16:1-16). What God promises He is able to perform at any time. A more intimate friendship with Abraham demands that God reveals Himself to Abraham with a different name.

At the conclusion of the covenant-making process, God gave Abraham his new name. ${ }^{1}$ A deeper nature of friendship requires God to change Abram's name. The new name indicates that the new-covenant relationship was sealed and the divine promise was certain. ${ }^{2}$ Therefore, it is stated in Gen 17:5, "A father of many nations I have made thee. Finally, circumcision was introduced as a sign of the covenant relationship between God and Abraham (Gen 17:11). ${ }^{3}$

In an explicit statement, God charges Abraham and his seed after him to "keep" the covenant that He made with them (Gen 17:9). In the same chapter of Genesis, we also find that this covenant can be "broken" (Gen 17:14). So evidently, Abraham's covenant relationship with God can be either kept or broken by Abraham. ${ }^{4}$ Therefore, the Abrahamic covenant was conditional in that it required the one with whom the covenant was made to be faithful to the Lord (Gen 18:18,19). Abraham was to train his family and household in the way of the Lord, so that when he died, his offspring and posterity would

${ }^{1}$ See Gen $12: 1 ; 15: 1 ; 17: 1,5$. His name is changed from "Abram" meaning "father is exalted," to Abraham, "father of a multitude." $\mathrm{He}$ is the first person in the Bible to receive a new name from God.

${ }^{2}$ Kenyon, 15.

${ }^{3}$ Ibid. This sign distinguished Abraham's descendants from the Gentiles. See Eph 2:11. It perpetuated the memory of God's covenant (Gen 17:11) and symbolized a circumcision of the heart. Plus, it fostered the cultivation of moral purity. See Deut 10:16 and Rom 2:29.

${ }^{4}$ Intrater, 27. 
live as he had lived. Thus, Abraham's descendants would also have to keep the way of the Lord, so that the Lord could "bring upon Abraham that which he hath spoken" (Gen 18:19). This friendship with the Lord is a matter of choice.

Faith in God affected Abraham's choice to continue to follow God's plan in history and not take history into his own hands. ${ }^{1}$ For Abraham to follow God's plan in history ultimately meant obedience to the point of the sacrifice of his only son (Gen 22:16-18). The act of Abraham's faith is an unreserved and unconditional placing of one's self into the hands of God to be directed by God's wisdom and governed by His laws. Abraham's faith provides security in the Lord, the Lord of the covenant, the Lord who evokes faith within the one who listens to his Lord. The faith of Abraham is reckoned as righteousness that finds its security in the Lord. It grounds one's whole life and existence in the covenant of God, and it sings praises to God. ${ }^{2}$ The Lord's friendship with Abraham and his seed would provide the means by which God could save humanity. The Lord extends His offer of friendship with humankind through Moses and His people, Israel. The Lord's action of intimate friendship with Abraham, Moses, and Israel is further evidence of God's demonstration of friendship evangelism.

\section{God's Relationship with Moses}

God, in His love, chooses or elects Moses and the people of Israel. It is an act of God's gracious and loving initiative, just as in previous covenants made with the

${ }^{1}$ Ibid. See Gen 22. Abraham becomes a model of all who are justified by faith (Gen 15:6; see Rom 4) and demonstrates that justifying faith is always accomplished by obedience to God's law (Gen 26:5).

${ }^{2}$ Trumbull, 224. 
patriarchs. ${ }^{1}$ God's choice of Moses and Israel was not determined by characteristics or excellencies, but grounded supremely in God's giving His undeserved love and grace to His leader, Moses, and His people, Israel. ${ }^{2}$ This means that God's redemptive acts rest solely in His nature and is part of what His character is like.

The nature of the Lord's friendship with Moses and Israel determines what name He chooses to make known. Moses asked God what he should answer when Israel asked, "What is his name?" (Exod 3:13). In this question Moses posed, the interrogative mah is used. This type of interrogative seeks out the power, qualities, and character of God. The answer sought by the question as here worded calls not for a name or title or designation, but rather for the meaning of God's name: "I AM THAT I AM" (Exod 3:14). Simply put, "Who is the Lord?"

Gerhard F. Hasel explains the significance of God's name and His character revealed in that, "God showed Himself to Abraham, Isaac, and Jacob in the character and significance of God Almighty, but in the character and significance of His name Yahweh He did not make Himself known. Thus the new aspect of the character of God and its significance that comes to view here is that He will reveal Himself in redemption, in setting Israel free from bondage, in making Israel His special covenant people, and in providing the means for them to remain His covenant people through His grace and His enabling power."

The Lord established His friendship with Israel by delivering Israel from the

${ }^{1}$ Richards, 40.

${ }^{2}$ See Exod 3:1-10; 2:11-15; Deut 4:37; 7:6-8.

${ }^{3}$ Hasel, 66 . 
Egyptian bondage. Yet the Lord wants Israel to choose to be His friend by entering a covenant relationship. The point is God first redeemed His people by liberating them from Egyptian slavery and bondage. God then engaged in another act of salvation and redemption by establishing a covenant relationship with Israel (Exod 19:4). ${ }^{1}$ God's act of freeing His people from Egyptian subjugation is called an act of His love (Exod 15:13; Deut 33:3). It is said of Israel that "the Lord loves you". (Deut 7:8). But God loves not only Israel or every member of those who belong to Israel, He loves also the stranger or foreigner in their midst (Deut 10:18). God's love for His people is His saving and redeeming activity for humanity. In every respect, God's love, initiative, mercy, redemptive design, all totally initiated and totally grounded in God himself, come to the forefront (Exod 6:4-8; Ps 106:45). God's friendship is extended to all people through Israel.

It was one thing to be set free from slavery, but quite another to remain free spiritually, physically, and otherwise. God designed that the covenant which $\mathrm{He}$ offered to His people would establish the deepest, most profound, and most intimate relationship possible between Him as their God and Israel as His people (Exod 19:5, 6). This partnership was to give the people of Israel security, protection, and blessing in every sphere of life. God required a positive commitment of Israel. In choosing to enter a covenant relationship with God, Israel alone could continue to function in a unique way, totally free and totally dedicated to their Lord (Exod 19:5, 6; 24:7). By choosing to be friends with God, Israel is allowed to enter a deeper relationship with Him.

${ }^{1}$ Kenyon, 22, 25. God liberated Israel from Egyptian bondage as an act of free grace and divine love. Love, election, and redemption are gifts of God totally undeserved. 
God planned to make Israel a treasured possession, or a "peculiar treasure" (Exod 19:5). Israel was set aside for a marked purpose. ${ }^{1}$ The idea of a treasured possession thus implies special value and a special relationship. God wanted to make Israel a "kingdom of priests" (Exod 19:6). This expressed purpose seemed to communicate that Israel was to function as a kingdom made up of priests. Each Israelite was to function as God's priestly agent to bring blessings to the nations of the entire world and to minister to the nations' needs. This special relationship was also fostered in the expression "holy nation" (Exod 19:6). It expressed that Israel had been separated or set apart from the other nations by God's grace for a special purpose (Deut 26:19). Israel was set apart to belong to God and to reveal in the quality of its total life and existence the covenant relationship into which God had placed it, and to lead others into the same relationship. The Lord expected His friendship with Israel would mature. Israel was to be God's witness to other nations by way of their special friendship with the Lord. Evangelism among the nations was to be fostered through the covenant relationship with Israel. However, the nation of Israel failed to meet God's ideal for them and was reduced to the simple level of a politicalnational entity. Later, the apostle Peter applied these same descriptive phases, "peculiar treasure" and "holy nation," to the New Testament church with the same implications of evangelizing the world with the good news of Jesus Christ (1 Pet 2:9). ${ }^{2}$ The Lord expects the New Testament church to engage in evangelism with people through the member's friendship with Christ.

This covenant relationship involves friendship and communion. No relationship

\footnotetext{
${ }^{1}$ See Deut 7:6; 14:2; 26:18, 19.

${ }^{2}$ Heppenstall, 443.
} 
and no true communion can exist between two individuals without a set of norms defining the basis on which the relationship or communion is to function. The law (Exod 20:1-17) thus becomes an instrument defining all relationships within the covenant and the covenant community. ${ }^{1}$ It defines the God-human relationship on the vertical plane. It also defines the interpersonal relationships on the horizontal plane. The law is God's divine instrument for defining relationships in which faith responds to love in obedience. The believer keeps the law because he or she remembers the salvation that God has already provided (Exod 20:1, 2). P. C. Craigie states that the Ten Commandments were "representative of God's love in that its injunctions, both negative and positive, led not to restriction of life, but to fullness of life. It demanded a response of love, not because obedience would somehow accumulate credit in the sight of God, but because the grace of God, experienced already in the liberation from Egypt and in the divine initiative in the covenant promise, elicited such a response from man in gratitude."

At the heart of the Ten Commandments, the Sabbath stands as the covenant sign between God and Israel. ${ }^{3}$ The Sabbath, as a sign, imparts to the believer first of all the knowledge that the Lord is the believer's covenant God. The Sabbath identifies God's sphere of authority and ownership as the "heavens and earth, the sea, and all that is in them" (Exod 20:11;31:17). It also indicates that the Lord "sanctifies" His people by

${ }^{1}$ Richards, 40.

${ }^{2}$ P. C. Craigie, The Book of Deuteronomy (Grand Rapids, MI: Wm. B. Eerdmans Publishing Co., 1976), 150.

${ }^{3}$ Heppenstall, 487. See Exod 20:8-11;31:13. Compare Ezek 20:12.

${ }^{4}$ See Lev 20:8; 21:8; 22:32; Ezek 37:28. 
making them his "holy" people.' The Sabbath functions as a seal of the relationship between God and His own people. In keeping the seventh-day Sabbath, the believer acknowledges the Lord as Creator, Re-creator, Redeemer, and Sanctifier. The believer also acknowledges thereby God's ownership and authority over all creation, including humanity. ${ }^{2}$ It makes the believer part of God's covenant community of true worshippers who "serve" God (1 Chr 28:9), "believe" Him (Isa 43:10), "trust" Him (Ps 9:10), "seek" Him (Ps 9:10), and "call on" His name (Jer 10:25; Ps 79:6). The law and the Sabbath helped define the terms and parties involved in the friendship between the Lord and His people. Both belong to each other.

\section{God's New Covenant Relationship}

God's friendship with Israel is nurtured through the major and minor prophets of Israel. Several prophets, including Hosea, Isaiah, Jeremiah, and Ezekiel, prophesied about the new covenant experience. ${ }^{3}$ Yet, the designation "new covenant" (Jer 31:31) appears only once in the Old Testament. The prophet Jeremiah, who prophesied during the last days of the southern kingdom of Judah, when the people of God were about to go into the Babylonian captivity, announced that a new covenant would come, "Behold, the days come, saith the Lord, that I will make a new covenant with the house of Israel, and with the house of Judah: not according to the covenant that I made with their fathers in the day that I took them by the hand to bring them out of the land of Egypt; which my covenant

\footnotetext{
'See Exod 19:6; Deut 7:6; Lev 19:2, 3.

${ }^{2}$ Heppenstall, 490-492.

${ }^{3}$ Heppenstall, 455. See Hos 2:18-20; Isa 65:17-66; Jer 31:31-34; Ezek 36:26-28.
} 
they brake, although I was an husband unto them, saith the Lord (Jer 31:31, 32)."

Even though the "new covenant" is designated with the adjective "new" for the first time in Jer 31:31, about 150 years before Jeremiah prophesied the prophet Hosea in the northern kingdom of Israel predicted a new covenant also, "And in that day will I make a covenant for them with the beasts of the field, and with the fowls of heaven, and with the creeping things of the ground; and I will break the bow and the sword and the battle out of the earth, and will make them to lie down safely. And I will betroth thee unto me for ever; yea, I will betroth thee unto me in righteousness, and in judgment, and in lovingkindness, and in mercies. I will even betroth thee unto me in faithfulness: and thou shalt know the Lord (Hos 2:18-20)."

The picture of a future covenant involving the animal kingdom as well as people and promising abolition of weapons of war and the introduction of peace is certainly a picture of the future Messianic reign of peace.

So, the new covenant of Jer 31:31 is not so "new." The term used with regard to the new covenant of Jer 31:31 is the Hebrew chadas. This Hebrew term means frequently "to renew" or "to restore"; and something "new" which was not yet present in the same quality or way before. Reflecting both ideas, the "new covenant" is simply a "renewed" or "restored' covenant, plus one now having characteristics not present in the same way or quality as before. ${ }^{1}$

When one compares the new covenant of Jer 31:31-34 with the "old covenant" involving ancient Israel on Mount Sinai, one see's God's acts of restoration with Israel. Again, God initiates the covenant-making relationship with His people (the partners are

${ }^{1}$ Heppenstall, 456-457. 
the same) when He states, "I will make a new covenant with the house of Israel, and with the house of Judah" (Jer 31:31). God is the initiator of salvation, "I will forgive their iniquity, and I will remember their sin no more" (Jer 31:34). The promise of divine fellowship and communion remains the same, "I will be their God and they shall be my people" (Jer 31:33). The law remains the same. God speaks of a new. covenant, not a new law. His law is not faulty and was not done away. ${ }^{1}$ The law as a way of life gives expression to this new covenant relationship.

The new dimension to this covenant relationship is God's activity in writing His law upon the human heart by His divine and enabling grace. ${ }^{2}$ It is God's work to write the law inwardly through His Holy Spirit (Ezek 36:26). Thus, the law becomes internalized within the believers' will, permeating it so as to make the human will and the divine law conform perfectly to each other (2 Cor $3: 5,6)$.

While the Lord offered the "new covenant" first to His people whom He elected and with whom He had made a covenant on Mount Sinai in the times of Moses, eventually the Lord had to turn from natural, ethnic Israel to spiritual Israel to find the cooperation he needed in putting into operation the provisions and benefits of his everlasting covenant, now being called the new covenant.

The members of the "new covenant" community are not every blood descendant of Abraham, but every person (regardless of whether the person is Jew or Gentile, black or white, yellow or brown, male or female) who allows God to write his law inwardly. ${ }^{3}$

'See Exod 24:12; 31:18; 34:1, 28; $1 \mathrm{Kgs} \mathrm{8:21;} \mathrm{Jer} \mathrm{31:33.} \mathrm{God's} \mathrm{law} \mathrm{is} \mathrm{immutable}$ and eternal.

${ }^{2}$ See Jer 24:7; 31:33; and Ezek 36:26-28.

${ }^{3}$ Heppenstall, 475. See Rom 11:12-24; Eph 2:12, 19. 
This internal writing of the law within the heart of the believer is the work of the Holy Spirit. Paul stresses that the new covenant is a covenant of the Holy Spirit, the believer now serving in the newness of the Holy Spirit. ${ }^{1}$ Thus the newness of the covenant is characterized most effectively by the word "better" (Heb 8:6). The new covenant would also establish a lasting, profound, and deep relationship and communion between the human partners and their covenanting Lord, the God of their salvation. Christ is mediating the "new covenant" (Heb 9:15, RSV). The forgiveness of sin under the new covenant can be called superior in the sense that it is secured in the death of Christ on the cross (Heb 9:15; Matt 26:28). Therefore, spiritual Israel is made up of those who allow God to internalize His law within them, and who thereby become sanctified channels of God's grace, to enlighten and bless humanity by sharing the good news of salvation in Jesus Christ.

\section{Friendship Evangelism in the New Testament}

As with Adam and Eve, Noah, Abraham, Moses, the nation of Israel, and His prophets in Old Testament times, the Lord has always taken the initiative to reveal himself to lost humanity. His goal has always been for lost humanity to enter an intimate, personal, saving covenant relationship with Him. The apostle Peter makes the astonishing claim that in Jesus Christ alone can humanity find salvation. "And there is salvation in no one else; for there is no other name under heaven that has been given among men, by which we must be saved" (Acts 4:12, NASB). Jesus Christ is the grand focal point of salvation.

\footnotetext{
${ }^{1}$ Heppenstall, 481-487. See Rom 7:6; 2 Cor 3:6.
} 
Yet, Christ chooses to engage salvation with people through establishing friendships. In Christ's pronouncement "I am come that they might have life, and that they might have it more abundantly" (John 10:10), Jesus sums up the divine answer to the quest for life at its best. This invitation was made available to sinners, the lost, the straying, the beggars, the burdened ones, the hungry and thirsty, all of whom Jesus came to save. ${ }^{1}$ Jesus, the master evangelist, modeled friendship evangelism (relationship evangelism) when He mingled with all types of people. He had something different to say to each person. ${ }^{2}$ He sought out rich people like Zacchaeus (Luke 19:1-10), poor people like blind Bartimaus (Mark 10:46-52), religious people like Nicodemus (John 3), social people like those at the wedding of Cana (John 2), working people like James and John (Luke 5:1-11), people possessed with evil spirits like the Gadarene demoniac (Mark 5:120) and despised people like Matthew, Levi, and his friends (Mark 2:14-17). Delos Miles, in his book Master Principles of Evangelism, indicates that there are at least thirty-five examples of Jesus ministering to people personally. ${ }^{3}$ In Christ's time, friendships served as effective bridges for the promotion and acceptance of the gospel, "Andrew found his own brother, Simon, and brought him to Jesus (John 1:41-42). Andrew had been introduced to Jesus by John the Baptist, Jesus'cousin (John1:35-37). Another man, Philip, was from the same town as Andrew and Peter. When he met Jesus, he soon brought

\footnotetext{
${ }^{1}$ Mark 2:14-17; Matt 5:6; 11:28-30; 22:9; Luke 14:21-23; 15; 19:10; John 7:37, 38.

${ }^{2}$ Don Posterski, Why Am I Afraid To Tell You I'm a Christian (Downers Grove, IL: InterVarsity Press, 1983), 17.

${ }^{3}$ Delos Miles, Master Principles of Evangelism (Nashville, TN: Broadman Press, 1982), 11. For a listing of the thirty-five examples of Jesus' ministry to individuals, please refer to appendix A.
} 
Nathaniel to him as well (John 1:45). It is clear in these cases and others that the good news moved quickly along the lines of relationship."

The book of Acts, which serves as a model for effective witnessing in contemporary society, demonstrates that friendship evangelism was a most effective method to bring people from all nations to faith in Jesus Christ. Carlos G. Martin makes the observation that many baptisms took place through a network of personal relationships, "Lydia, the businesswoman from Philippi, was baptized with her household (Acts 16:14, 15). The Philippian jailer 'believer in God with all his household,' and they were baptized together on the night of his conversion (16:30-34). In preparation for Peter's arrival, Cornelius 'had called together his relatives and close friends' (10:24)."2

It is evident that in New Testament times not only did all the early Christians witness, but they witnessed daily and to everyone they met—especially to those who were in their network of friends, relatives, associates, and neighbors. Evangelism was not a special activity to be undertaken at a prescribed time, such as a once-a-year crusade or a once-a-week visitation effort, but was the constant overflow of individual and corporate experiences and knowledge of Christ. Listed above are some examples how Christ and early believers used their relationships as bridges by which to share the gospel.

\section{The Need for Friendship Evangelism}

There are significant reasons why friendship evangelism is important. First, friendship evangelism has proven to be the most effective method of bringing people to

\footnotetext{
${ }^{1}$ Wayne McDill, Making Friends For Christ (Nashville, TN: Broadman Press, 1979), 15.

${ }^{2}$ Carlos G. Martin, Turning the World Upside Down (Nampa, ID: Pacific Press Publishing Association, 2000), 53.
} 
faith in Christ. Evangelism at its best flows from relationships. While public evangelistic meetings, television ministries, and door-to-door evangelism all have their place in reaching people for Christ, the most effective means of reaching the world is to reach out to those nearest to you. Be willing to build relationships with people who do not know Christ. ${ }^{1}$ Every Christian can assume responsibility for sharing the gospel in the context of daily life. ${ }^{2}$ Every believer has the opportunity to witness in the context of his or her own relationship with people. Wherever the believer is going, whatever the believer is doing, the believer should consciously work at building relationships that will open doors to lead people to the gospel. ${ }^{3}$

Second, the emphasis of friendship evangelism is people, not process; discipleship, not simply membership; growing people in Christ, not simply winning people to Christ. ${ }^{4}$ It allows people to grow up in the image of Christ. The apostle Paul declares, "As therefore you received Christ Jesus the Lord, so live in him, rooted and built up in him and established in the faith, just as you were taught, abounding in thanksgiving" (Col 2:6, 7). So, friendship evangelism is not only effective in bringing people to Christ, but establishing people in Christ. Friends not only bring friends to Christ, but friendships with other church members is the first step of a new believer's assimilation into the church. If new members do not have a minimum of seven friends in

${ }^{1}$ Daryl G. Donovan, Men Mentoring Men: A Men's Discipleship Course (Lima, OH: CSS Publishing Company, Inc., 1998), 187.

${ }^{2}$ D. James Kennedy, Evangelism Explosion (Wheaton, IL: Tyndale House Publishers, Inc., 1996), 4.

${ }^{3}$ James Zackrison, Power to Witness (Nampa, ID: Pacific Press, 1993), 48.

${ }^{4}$ Larry Keefauver, Friends \& Faith: Friendship Evangelism in Youth Ministry (Loveland, CO: Group Books, 1986), 14. 
the church within the first six months, they will be on their way out the back door. ${ }^{1}$ Every believer has an opportunity to participate in the Great Commission (Matt 28:18-20). The ability to share the gospel of Christ with a friend in the context of his or her own relationship with Christ is the key to friendship evangelism. The objective centers on a friend sharing his or her friend (Christ) with another friend. ${ }^{2}$

\section{The Advantages of Friendship Evangelism}

There are several distinct advantages of friendship evangelism in bringing people to faith in Christ. ${ }^{3}$ Friendship evangelism presents a natural opportunity of leading people to Christ. Every human being is the center of a network of relationships. ${ }^{4}$ Each person was born to a mother and father, and may have brothers and sisters, grandparents, aunts and uncles, cousins, nephews and nieces. When one marries, this network is enlarged significantly. When a person's work associates, neighbors, and strangers encountered during the course of a day are added, the network is broadened even more. Every believer should spend time socializing with non-Christians by sharing meals, attending sporting events, or going to a concert to enlarge his or her network of influence.

Friendship evangelism is built on a demonstrated love for the individual. ${ }^{5}$ Each day affords a believer an opportunity to make a commitment to establish a meaningful

\footnotetext{
'Win Arn, The Church Growth Ratio Book (Pasadena, CA: Church Growth, 1987), 23.

${ }^{2}$ Keefauver, 17.

${ }^{3}$ For a partial list of biblical examples of friendship evangelism see appendix B.

${ }^{4}$ Kennedy, 20, 21.

${ }^{5}$ Philip G. Samaan, Christ's Way of Reaching People (Hagerstown, MD: Review and Herald Publishing Association, 1990), 66.
} 
relationship with non-Christian people. By communicating acceptance and affirmation, those on the receiving end become more receptive to the gospel message. ${ }^{1}$ There is a base of trust because the witness has been first and foremost a friend who deeply cares and listens. Your friendship has earned you the right to share the gospel. ${ }^{2}$

In addition to the afore-mentioned, advantages, friendship evangelism is adaptable and flexible. It does not require detailed planning and logistical preparation. Friendship evangelism personalizes the message suitable for the occasion. The witness' eyes, voice, and posture convey compassion and honest concern for the friend. ${ }^{3}$ Friendship evangelism needs no advance staging. One uses the normal events of the day to share the gospel's content. While friendship evangelism can be used independently of other forms of evangelism, it is flexible enough to be used within the framework of other forms of evangelism. For example, while Jesus was preaching to the masses, Andrew was busy developing a friendship with the boy with the five loaves and two fishes (John 6:1-14).

Friendship evangelism is based on a relational caring approach. ${ }^{4}$ Because it is friendship based, it is inclusive. People of all ages, genders, and cultures are afforded an opportunity to witness. Every person who desires to share the good news of Christ is welcomed.

Friendship evangelism has built in follow-through. The witness, being a friend, is

${ }^{1}$ Jard DeVille, The Psychology of Witnessing (Silver Spring, MD: The Ministerial Association General Conference of Seventh-day Adventists, 1996) 47.

${ }^{2}$ McKay, 65 .

${ }^{3}$ Posterski, 17, 21.

${ }^{4}$ Phillip G. Samaan, Christ's Way of Making Disciples (Hagerstown, MD: Review and Herald Publishing Association, 1999), 39. 
then a natural source for nurture. Moreover, the witness' church provides effective help in follow-through and assimilation into the community of faith. At the same time, it allows the new convert opportunities for discipleship in everyday life situations. The person has become involved with his or her unbelieving friends, relatives, and neighbors with the intent of sharing the good news of Christ on a daily basis (John 4). ${ }^{t}$

\section{The Role of Laity in Bringing People to Christ}

For friendship evangelism to become a reality in the local church, a correct understanding of the term "laity" needs to be understood. As the church developed during the Middle Ages, the term "laity" was misunderstood to imply a false dichotomy between clergy and laity. The idea emerged that only a specialized group, separate from the rest of people of God, was truly ministers. This specialized group became known as clergy. Those who were not a part of this special group became known as lay persons. In the New Testament a careful study of the word "laity" reveals no such dichotomy exists. Clergy and lay persons alike are laity. The church is a priesthood. Every believer is a priest and as such is a minister with a ministry to perform. All believers are chosen, a part of the chosen priesthood, and called to work for the salvation of others.

\section{Clergy-Laity Dichotomy}

During the fourth and fifth centuries, a great misunderstanding (which in some churches exist today) developed concerning the nature of the church. A sharp division arose between the church leaders and the people. This division reached its peak during the Middle Ages when the papacy was at the zenith of its power. The word "laity" is derived

'Kennedy, 22, 23. 
from the Greek root "ho laos." Its basic meaning is "people of God."

The medieval church declared there were two kinds of Christians: a spiritually weak laity and a spiritually strong clergy. The church stated there were two types of vocations, a secular calling pursued by laity, and a spiritual calling engaged by the clergy. This teaching gave rise to the idea that there were two kinds of rewards. The laity received an ordinary reward while the clergy received a special reward. ${ }^{2}$

The Middle Ages dichotomy between clergy and laity led to the idea that only the clergy could understand and explain the Bible. Since the laity was considered "inferior," their individual judgment on all biblical matters were subjugated to those of priests. The priests were the custodians of truth and their judgment was supreme. The laity was to support the church by attendance, offerings, and limited participation. Hendrick Kramer in his work, The Theology of the Laity, highlights why clergy and laity were defined along the lines of professional vocation:

The Reformation coupled with its radical elimination of the distinction between "clergy" and "laity" placed a vehement stress on the pre-eminence of the preaching office. This vehement stress on correct preaching required a specially qualified group of bearers of office. ... It tended toward a reestablishment of a kind of "clergy"... . It encouraged the practical recognition of a secondary status of the "laity" in comparison with the ministry, the breeding of an attitude of passivity in the laity as a whole, the accentuation $f$ the significance of "office" and its leadership. ${ }^{3}$

The Reformers believed that both the vocation of the clergy and laity were

${ }^{1}$ Russell Burrill, Revolution in the Church (Fallbrook, CA: Research Center, 1993), 33.

${ }^{2}$ Sakea Kubo, The God of Relationships (Hagerstown, MD: Review and Herald Publishing Association, 1993), 149.

${ }^{3}$ Hendrick Kramer, $A$ Theology of the Laity (Philadelphia, PA: Westminister Press, 1958), 65,66 . 
spiritual, but the office of the clergy was different from that of the laity. ${ }^{1}$ The clergy is called to the office of pastoral ministry. One is employed by the church and trained in theology. Later the pastor is ordained for a leadership position in the church. On the other hand, the laity have no call to the ministry. Its members are not employed by the church or trained in theology. Neither are they ordained for ministry. This gave rise to the word "minister" as a title reserved for the pastors, clergy, or other church officials. The title "minister" for clergy fostered service in leadership, and the lack of the title "minister" for laity resulted in the absence of ministry. ${ }^{2}$

\section{Biblical View of Laity}

A study of the word "laity" reveals that it is derived from the Greek word laos, which means "people," usually God's chosen people, the Christians. Luke declares: "How God at the first did visit the Gentiles, to take out of them a people (laos) for his name" (Acts 15:14). ${ }^{3}$ Peter affirms this idea of laos being God's people by attributing to the New Testament church terms ascribed only to Israel, God's people in the Old Testament, "But ye are a chosen generation, a royal priesthood, an holy nation, a peculiar people [laos]; that you should show forth the praises of him who hath called you out of darkness into his marvelous light. Which in time past were not a people [laos], but are now [laos] the people of God; which had not obtained mercy, but now have obtained mercy," (1 Pet 2:9, 10, italics added).

'Oscar E. Feucht, Everyone a Minister (St. Louis, MO: Concordia Publishing House, 1986), 63.

${ }^{2}$ Kubo, 152-154.

${ }^{3}$ Ibid., 57. 
In the New Testament the term laos is used 140 times alone. In each instance, the term laos includes the entire people of God. The laity are God's people in the world. Laity is never used in the Bible in contrast with pastors, lay persons, or church administrators. The laity are God's people who possess various gifts for ministry [service]. ${ }^{1}$

For further clarification, the word "clergy" is derived from the Greek word kleros. It originally meant the object used in drawing lots to choose a person for a position. It is related to the verb "call" and is employed in the Greek New Testament when referring to the Holy. Spirit calling a person by the Gospel into the Christian fellowship of the church. ${ }^{2}$

Paul uses the terms in reference to members of the community of faith: "called to be saints" (1 Cor 1:2); and "walk worthy of the vocation wherewith you are called" (Eph 4:1). Oscar E. Feught informs us that, "All Christians are God's called people, God's 'clergy' in the world! Even the Greek word for the church, ekklesia, is derived from the basic term 'to call'... all Christians are God's laity (laos) and all are God's clergy (kleros). Any distinction we make between clergy and laity cannot clear the laity from being ministers of the Gospel or being responsible as God's 'clergy.",3

\section{Priesthood of All Believers}

The New Testament teaches that all Christians are to be ministers. ${ }^{4}$ Each member

${ }^{1}$ Rex D. Edwards, Every Believer a Minister (Silver Spring, MD: Ministerial Association of General Conference of Seventh-day Adventists, 1995), 13.

${ }^{2}$ Ibid.

${ }^{3}$ Ibid., 57,58 .

${ }^{4}$ Ibid., 13. 
is called to be a priest. Peter declared, "You are a chosen race, a royal priesthood, a dedicated people claimed by God for his own, to proclaim the triumphs of him who has called you out of darkness into his marvelous light" (1 Pet 2:9, NEB). The church is a priesthood where each person is a priest. ${ }^{1}$ Each believer has the responsibility and privilege of sharing the gospel to the world. ${ }^{2}$ There is no difference in the status of clergy and believers. The only difference is in the role of service. There is a difference of function, not standing in relationship to God or with humanity. Together clergy and believers compose the body of Christ, together they make up the church, and together they are responsible for ministry. ${ }^{3}$ The church is a kingdom of priests who enlarge the kingdom of God on earth. The laity, the entire people of God, is composed both of pastors, whose prime function is spiritual nurture and training, and of believers, who, with their pastor, carry out the ministry of the church. ${ }^{4}$

\section{Ellen G. White and the Role of the Laity}

Ellen G. White's books, articles, and statements on the importance of personal involvement of the entire church membership in the work of salvation are well documented. White strongly advocated the primary role of the non-clergy members in doing the work of evangelism. She declared what the Scripture admonishes, that every person in the community of faith is obligated to share the gospel.

'Burrill, Revolution in the Church, 24.

${ }^{2}$ Kubo, 146.

${ }^{3}$ Russell C. Burrill, The Life and Mission of the Local Church (Fallbrook, CA: Hart Research Center, 1998), 72, 73.

${ }^{4}$ Kubo, 153. 
Lay Participation in the Great Commission

White often expressed her concern for active involvement of the members in fulfilling the Great Commission. ${ }^{1}$ While addressing the issue of non-clergy participation, she usually admonished pastors to provide the necessary training. She counseled that coupled together, both the church members and the souls won for Christ would benefit from this training. The following quotes convey her position correctly:

Every member of the church should be instructed in a regular system of labor. All are required to do something for the Lord. They may interest persons to read; they may converse and pray with them. The minister who shall educate, discipline, and lead an army of efficient workers will have glorious conquests here, and a rich reward awaits him when, around the great white throne, he shall meet those saved through his influence. ${ }^{2}$

In every church the members should be so trained that they will devote time to the winning of souls to Christ. How can it be said of the church, "Ye are the light of the world," unless the members of the church are actually imparting light? Let those who have charge of the flock of Christ awake to their duty, and set many souls to work. ${ }^{3}$

\section{Laity Involvement in Friendship Evangelism}

White also discussed the influence of kindness and love in sharing the gospel. She declared that "the strongest argument in favor of the gospel is a loving and lovable Christian." White highlighted the importance of being a friend who serves as a liaison connecting non-Christians to Christ, while demonstrating to them that Christians need

${ }^{1}$ Ellen G. White, Gospel Workers (Washington, D.C.: Review and Herald Publishing Association, 1948), 29.

${ }^{2}$ Ellen G. White, Testimonies for the Church, 9 vols. (Mountain View, CA: Pacific Press Publishing Association, 1948), 5:308.

${ }^{3}$ Ibid., 6:436.

${ }^{4}$ Ellen G. White, The Ministry of Healing (Mountain View, CA: Pacific Press Publishing Association, 1942), 470. 
him as much as they do: "There are souls perplexed with doubt, burdened with infirmities, weak in faith, and unable to grasp the Unseen, but a friend whom they can see, coming to them in Christ's stead, can be a connecting link to fasten their trembling faith upon Christ."1

White assured believers that they could find "true success" in winning people to faith using Christ's methods. His methods were "accomplished by the power of persuasion, the power of prayer, and the power of the love of God" which cannot fail. ${ }^{2}$ White in The Ministry of Healing writes: "Christ's method alone will give true success in reaching the people. The Saviour mingled with men as one who desired their good. He showed His sympathy for them, ministered to their needs, and won their confidence. Then he bade them, 'Follow Me."'3 Philip Samaam, in his book Christ's Way of Reaching People, recommends that we divide and organize Christ's method of friendship evangelism found in Ministry of Healing into six progressive stages. ${ }^{4}$ Each step or stage represents a higher level commitment involved in friendship development. To witness effectively in friendship evangelism all one needs to do is to follow the progressive steps of Christ's method outlined from the counsel given in The Ministry of Healing: The six steps of Christ's method of friendship evangelism with additional support for each step from other writings of Ellen White are outlined:

1. Christ mingled with others as one desiring their good.

${ }^{1}$ Ellen G. White, Desire of Ages (Mountain View, CA: Pacific Press Publishing Association, 1940), 297.

${ }^{2}$ White, The Ministry of Healing, 143, 144.

${ }^{3}$ Ibid., 143.

${ }^{4}$ Samaan, Christ's Way of Reaching People, 40. 
Christian sociability is altogether too little cultivated by God's people.... Especially should those who have tasted the love of Christ develop their social powers, for in this way they may win souls to the Saviour. ${ }^{1}$

We are not to renounce social communion. We should not seclude ourselves from others. In order to reach all classes, we must meet them where they are. They will seldom seek us on their own accord ... in the home of the lowly, and in the great mansion of the great, at the hospitable bed, and in the gatherings of the innocent social enjoyment. ${ }^{2}$

We should all become witnesses for Jesus. Social power, sanctified by the grace of Christ, must be improved in winning souls for the Saviour. Let the world see that we are not selfishly absorbed in our own interests, but that we desire others to share our blessings and privileges. Let them see that our religion does not make us unsympathetic or exciting. Let all who profess to have found Christ, minister as He did for the benefit of men. ${ }^{3}$

Salt must be mingled with the substance to which it is added; it must penetrate and infuse in order to preserve. So it is through personal contact and association that men are reached by the saving power of the gospel. ${ }^{4}$

By being social and coming close to people, you may turn the current of their thoughts more readily than by the most able discourse. ${ }^{5}$

2. Christ sympathized with them.

The most successful toilers are those who cheerfully take up the work of serving God in the little things. The work of Christ was largely made up of personal interviews. He had a faithful regard for the one-soul audience. From that one soul the intelligence received was carried to thousands. ${ }^{6}$

By personal labor reach those around you. Become acquainted with them. This work cannot be done by proxy. Money lent or given will not accomplish it. By

${ }^{1}$ White, Testimonies, 6:172.

${ }^{2}$ White, Desire of Ages, 152.

${ }^{3}$ Ibid.

${ }^{4}$ Ellen G. White, Thoughts From the Mount of Blessing (Mountain View, CA: Pacific Press Publishing Association, 1956), 36.

${ }^{5}$ White, Gospel Workers, 193.

${ }^{6}$ White, Testimonies for the Church, 6:115. 
visiting the people, talking, praying, sympathizing with them, you will win hearts. To do it, you will need resolute, persevering faith, unwearying patience, and a deep love for souls. ${ }^{1}$

In Christlike sympathy we should come close to men individually, for while logic may fail to move, and argument be powerless to convince, the love of Christ, revealed in personal ministry, may soften the stony heart. ${ }^{2}$

True sympathy between man and his fellow man is to be the sign distinguishing those who love and fear God from those who are unmindful of His law. ${ }^{3}$

3. Christ ministered to their needs.

Many have no faith in God and have lost confidence in man. But they appreciate acts of sympathy and helpfulness. As they see one with no inducement of earthly praise or compensation coming to their homes, ministering to the sick, feeding the hungry, clothing the naked, comforting the sad, and tenderly pointing all to Him ... as they see this, their hearts are touched. Gratitude springs up, faith is kindled. They see that God cares for them, and as His Word is opened they are prepared to listen. ${ }^{4}$

Wherever the church is established, all the members should engage actively in missionary work. They should visit every family in the neighborhood, and know their spiritual condition. ${ }^{5}$

4. Christ won their confidence.

Much depends upon the manner in which you meet those whom you visit. You can take hold of a person's hand in greeting in such a way as to gain his confidence at once, or in so cold a manner that he will think you have no interest in him. ${ }^{6}$

'Ibid., 9:41.

${ }^{2}$ Ellen G. White, Christ's Object Lessons (Mountain View, CA: Pacific Press Publishing Association, 1941), 57.

${ }^{3}$ Ellen G. White, Medical Ministry (Mountain View, CA: Pacific Press Publishing Association, 1963), 251.

${ }^{4}$ Ibid., 247.

${ }^{5}$ Ellen G. White, Christian Service (Washington, DC: General Conference of Seventh-day Adventists, 1947), 12.

${ }^{6}$ White, Gospel Workers, 189. 
A man may not bear the most pleasant exterior, he may be deficient in many respects; but if he has a reputation for straightforward honesty, he will gain the confidence of others. ${ }^{1}$.

This simple straightforward, solid reliability in the daily deportment of a Christian will do more to foster and generate fidelity in others than all the preaching of a lifetime. Not only will it encourage our contemporaries to put confidence in us, but much more importantly it will lead them, eventually, to meet the Master and put their trust in Him. ${ }^{2}$

Christ was seeking to find the key to this heart, and with the tact born of divine love, He asked, not offered, a favor. The offer of a kindness might have been rejected; but trust awakens trust. The King of heaven came to this outcast soul, asking a service at her hands... . [He] was dependent upon a stranger's kindness for even the gift of a drink of water. ${ }^{3}$

In every human being He discerned infinite possibilities. . . Looking upon them with hope, He inspired hope. Meeting them with confidence, He inspired trust. ${ }^{4}$

5. Christ invited them to follow him.

There are souls perplexed with doubt, burdened with infirmities, weak in faith, and unable to grasp the Unseen, but a friend whom they can see, coming to them in Christ's stead, can be a connecting link to fasten their trembling faith upon Christ. ${ }^{5}$

As witnesses for Christ, we are to tell what we know, what we ourselves have seen and heard and felt. If we have been following Jesus step by step, we shall have something right to the point to tell concerning the way in which He has led us.... This is the witness for which our Lord calls, and for want of which the world is perishing. ${ }^{6}$

Our confession of His faithfulness is Heaven's chosen agency for revealing

${ }^{1}$ White, Testimonies for the Churches, 4:353.

${ }^{2}$ White, Thoughts From the Mount of Blessing, 134-135.

${ }^{3}$ White, Desire of Ages, 184.

${ }^{4}$ Ellen G. White, Education (Mountain View, CA: Pacific Press Publishing Association, 1952), 80.

${ }^{5}$ White, Desires of Ages, 297.

${ }^{6}$ Ibid., 340. 
Christ to the world. We are to acknowledge His grace as made known through the holy men of old; but that which will be most effectual is the testimony of our own experience. . . supported by a Christlike life [they] have an irresistible power that works for the salvation of souls. ${ }^{1}$

6. Christ promised to make them "fishers of men.",

When disciples came forth from the Saviour's training, they were no longer ignorant and uncultured. They had become like Him in mind and character, and men took knowledge of them that they had been with Jesus. ${ }^{3}$

He who called the fishermen of Galilee is still calling men to His service. .. . However imperfect and sinful we may be, the Lord holds out to us the offer of partnership with Himself, of apprenticeship to Christ. He invites us to come under the divine instruction, that, uniting with Christ, we may work the works of God. ${ }^{4}$

The first thing to be learned by all who would become workers together with God is the lesson of self-distrust. ... This is not to be gained through education in the most scientific schools. It is the fruit of wisdom that is obtained from the divine Teacher alone. ${ }^{5}$

If you go to work as Christ design that His disciples shall, and win souls for Him, you will feel the need of a deeper experience and a greater knowledge in divine things. ... Encountering opposition and trails will drive you to the Bible and prayer. ${ }^{6}$

If one questions when should one start witnessing as a friend of Christ to win people to him, White would counsel: "Every true disciple is born into the kingdom of

God as a missionary. No sooner does one come to Christ than there is born in his heart a

${ }^{1}$ Ibid., 347.

${ }^{2}$ White, The Ministry of Healing, 143.

${ }^{3}$ White, Desire of Ages, 250.

${ }^{4}$ Ibid., 297.

${ }^{5}$ Ibid., 250.

${ }^{6}$ Ellen G. White, Steps to Christ (Washington, DC: Review and Herald Publishing Association, 1908), 80. 
desire to make known to others what a precious friend he has found in Jesus; the saving and sanctifying trith cannot be shut up in his heart."

\section{The Biblical Role of the Pastor}

In order for friendship evangelism to be successful in the local church, pastors must resist the temptation to engage in ministry alone. Pastors are spiritual overseers of local congregation. This spiritual leadership and shepherding role of the pastor must be done in the context of equipping the members to perform the work of evangelism. Effective friendship evangelism is to be a united effort between pastors and their members for the salvation of others.

\section{Pastoral Leadership}

The pastors are the spiritual leaders of a congregation. In Acts 20:28 Paul uses a term which helps one to understand the work of the pastors: "Take heed therefore unto yourselves, and to all the flock, over which the Holy Ghost hath made you overseers." The word, "overseer" comes from the Greek word, "episkopous," which simply means bishop, elders, shepherds, or ministers. "Overseer" can be defined as "one who has the responsibility of caring for the spiritual concerns." The Apostle Paul wanted the pastors of the Ephesian church to assist people in their spiritual growth and celebrate good times with the people as well as pray for and help members in times of despair.

Yet, the pastor sometimes misapplies his or her responsibilities as "overseer" and

${ }^{1}$ White, The Ministry of Healing, 102.

${ }^{2}$ Cleon L. Rogers, Jr. and Cleon L. Rogers III, The New Linguistic and Exegetical Key to the Greek New Testament (Grand Rapids, MI: Zondervan Publishing House, 1998), 286. 
attempts to engage in too much work alone. White speaks to this problem, "Sometimes ministers do too much; they seek to embrace the whole work in their arms. It absorbs and dwarfs them; yet they continue to grasp it all. They seem to think that they alone are to work in the cause of God, while the members of the church stand idle. This is not God's order at all."1

Addressing this same problem, Russell Burrill declared that:

The work of the pastor is to prepare God's people to do the work of ministry. It is not the job of the pastor to be the only soul winner in the church. It is not the job of the pastor to do the work of ministry, but to train the members to do the work of the ministry. It is true the pastor ... performs ministry. He does give Bible studies, counsel, visit, etc. But whenever he does it, he is acting in the capacity of a layperson and is not functioning as a pastor. What the pastor is paid to do is to train the members. If he is not doing that, then biblically, he is not doing his job. ${ }^{2}$

When pastors learn their role is to be the leader of a team and that victories are won by teams, not "stars," the church will begin to move forward in adding members to the community of faith in an unprecedented manner. ${ }^{3}$ White gives the interesting illustration about the owner of a large mill who once observed his superintendent in a wheel pit making some minor repairs while a half-dozen workmen were standing idly by, just looking on. The owner immediately fired the man, not because he was lazy but because he was teaching the six men to be idle while he did the work they were supposed to do. ${ }^{4}$

${ }^{1}$ Ellen G. White, Evangelism (Washington, DC: Review and Herald Publishing Association, 1946), 113.

${ }^{2}$ Burrell, Revolution in the Church, 48.

${ }^{3}$ Stan Toler and Larry Gilbert, The Pastor's Playbook (Kansas City, MO: Beacon Hill Press of Kansas City, 2000), 9.

${ }^{4}$ White, Gospel Workers, 197. 
No person should attempt to do the work of six or more. Moses tried it and failed. His father-in-law, Jethro, saved Moses' life by advising him to delegate his responsibilities (Exod 18:14-27). The pastor is not only an overseer in the sense that he is in charge of the work of the church, but he is also a shepherd. This tender term, "shepherd," indicates that a true pastor feeds and cares for the community of faith. So, the twofold work of "leading" and "shepherding" rests squarely on the shoulders of the pastoral ministry.

Today more and more pastors are saddled with the responsibility of just one church. Many pastors scurry about settling problems, promoting various conference programs, taking near-full responsibility for erecting buildings and a hundred other details, while the membership sits back and begins to think, "We have done our part in returning our tithe and giving our offerings, therefore, we deserve to have a pastor who does the work for us." George Hunter states, "At least 90 percent of all congregations 'delegate' evangelism and membership recruitment to the ordained minister; 'That's your job, Pastor'."1

This concept of the ministry was never in God's plan. The church in general has suffered because of its failure to understand the true work of the pastoral ministry. Ellen White points out the results of misguided efforts, "God has not given His ministers the work of setting the churches right. No sooner is this work done, apparently, than it has to be done over again. Church members that are thus looked after and labored for become religious weaklings. If nine-tenths of the effort that has been put forth for those who have

${ }^{1}$ George G. Hunter III, How to Reach Secular People (Nashville, TN: Abingdon Press, 1992), 114. 
never heard the truth, how much greater would have been the advancement made! God has withheld His blessings because His people have not worked in harmony with His directions."

What are the implications of this statement? It simply means that pastors should not "hover over the churches already raised up, but that they should be doing aggressive evangelistic work." 2 This counsel is in harmony with the apostle Paul's admonition to the young pastor, Timothy, to be vigilant in making full proof of his ministry and do the work of an evangelist (1 Tim 4:5). The concept of pastors doing aggressive evangelistic work must be coupled with pastors training the members in doing evangelistic work, "The greatest help that can be given our people is to teach them to work for God, and to depend on Him, not on the ministers. Let them learn to work as Christ worked. Let them join His army of workers and do faithful service for Him."”

The spiritual leadership and shepherding responsibilities of the pastor should be done in the context of evangelism. First, the shepherding part of a pastor's work deals mainly with battling Satan in new territory by tearing God's sheep from Satan's clutches. Of course, some time must be spent in shepherding those who are already in the church; but this work shall decrease as the members mature spiritually. Second, the pastor plans work for the church members that are already in the faith by teaching the members of an established church how to care for themselves and how to go to work for others. White states emphatically that the pastor's first job is to train the members, even before reaching

\footnotetext{
${ }^{1}$ White, Testimonies for the Church, 7:18.

${ }^{2}$ White, Evangelism, 382.

${ }^{3}$ White, Testimonies for the Church, 7:119.
} 
out to unbelievers: "In laboring where there are already some in the faith, the minister should at first seek not much to convert unbelievers, as to train the church members for directions."

What are the implications of this statement? It simply means that pastors should not "hover over the churches already raised up, but that they should be doing aggressive evangelistic work." ${ }^{2}$ This counsel is in harmony with the apostle Paul's admonition to the young pastor, Timothy, to be vigilant in making full proof of his ministry and do the work of an evangelist (1 Tim 4:5). The concept of pastors doing aggressive evangelistic work must be coupled with pastors training the members in doing evangelistic work, "The greatest help that can be given our people is to teach them to work for God, and to depend on Him, not on the ministers. Let them learn to work as Christ worked. Let them join His army of workers and do faithful service for Him." ${ }^{33}$

The spiritual leadership and shepherding responsibilities of the pastor should be done in the context of evangelism. First, the shepherding part of a pastor's work deals mainly with battling Satan in new territory by tearing God's sheep from Satan's clutches. Of course, some time must be spent in shepherding those who are already in the church; but this work shall decrease as the members mature spiritually. Second, the pastor plans work for the church members that are already in the faith by teaching the members of an established church how to care for themselves and how to go to work for others. White states emphatically that the pastor's first job is to train the members, even before reaching

${ }^{1}$ White, Testimonies for the Church, 7:18.

${ }^{2}$ White, Evangelism, 382.

${ }^{3}$ White, Testimonies for the Church, 7:119. 
out to unbelievers: "In laboring where there are already some in the faith, the minister should at first seek not much to convert unbelievers, as to train the church members for acceptable co-operation."1

The Equipping Role of the Pastor

The pastor's primary role is to equip the membership for the work of ministry. According to the Apostle Paul who wrote to the church at Ephesus, Christ gave gifts to His church, "And he gave some apostles, some prophets, some evangelists, some pastors and teachers; for the perfecting of the saints, for the work of the ministry, for the edifying of the body of Christ: Till we all come in the unity of the faith, and of the knowledge of the Son of God, unto a perfect man, unto the measure of the stature of the fulness of Christ" (Eph 4:11-13).

Paul identifies in verse 11 , one of the gifts as being that of pastor-teacher. Verse 12 indicates the purpose of the pastor-teacher gift is "for the perfecting of the saints, for the work of ministry, for the edifying of the body of Christ." The New American Standard Version interprets "for the perfecting of the saints" as "equipping of the saints." The New American Standard Version interprets "for the work of ministry" as "for the work of service." In the New Testament, a saint is a member or believer of the community of faith. So the purpose of pastoral ministry is to equip the believers for the work of service. The Scripture declares a priority for pastoral ministry as the equipping, enabling, and training of membership for service. The pastor is the coordinator of all the gifts God has placed in the church. It is the pastor's responsibility to help members discover their gifts,

${ }^{1}$ White, Gospel Workers, 196. 
develop them, and direct them into service for Christ.

Concerning the equipping role of the pastor, White comments:

Just as soon as a church is organized, let the minister set the members at work. They will need to be taught how to labor successfully. Let the minister devote more of his time to educating than to preaching. Let him teach the people how to give to others the knowledge they have received. While the new converts should be taught to ask counsel from those more experienced in the work, they should also be taught not to put the minister in the place of God.... The power of the gospel is to come upon the companies raised up, fitting them for service. ${ }^{1}$

Those who have the spiritual oversight of the church should devise ways and means by which an opportunity may be given to every member of the church to act some part in God's work. Too often in the past this has not been done. Plans have not been carefully laid and fully carried out, whereby the talents of all might be employed in active service. There are but few who realize how much has been lost because of this. ${ }^{2}$

It becomes clear that friendship evangelism is to be a united effort between pastors and their members for the salvation of souls. But too often pastors yield to temptation and finds themselves "waiting on tables" with the members standing around complaining. ${ }^{3}$ Many pastors think that they are tending to the business of the church when in reality they are neglecting the work that they have been appointed to do. White highlights the problem:

Not a few ministers are neglecting the very work that they have been appointed to do. Why are those who are set apart for the work of ministry placed on committees and boards? Why are they called upon to attend so many business meetings, many times at great distance from their fields of labor? Why are not business matters placed in the hands of business men? The ministers have not been set apart to do this work. The finances of the cause are to be properly managed by men of ability; but ministers are set apart for another line of work. Let the management of financial matters rest on others than those ordained to the ministry. ${ }^{4}$

'Ibid., 20.

${ }^{2}$ White, Christian Service, 61.

${ }^{3}$ See Acts 6:1-4.

${ }^{4}$ White, Testimonies, 7:254-255. 


\section{Summary}

Friendship evangelism can be defined as the intentional sharing of the gospel of Christ by the community of faith through establishing caring relationships with persons who are not part of the community in order that they can be converted to the lordship of Jesus Christ. God has always sought an intimate relationship with humankind. Although sin caused a visible break in the relationship between God and humanity, the Lord took the initiative to seek to restore the fellowship and communion with lost humankind. This covenant relationship with God could be entered into by humanity accepting by faith, Christ as the atoning sacrifice of salvation.

Recognizing God's redemptive acts in one's life, the believer responds naturally by witnessing to others about the good news of God's saving grace in Christ. This activity on the part of the believer is called evangelism. It is driven by a love of God's saving grace springing forth within the life of the person saved. Therefore, the witness for Christ takes the initiative in seeking out lost persons and sharing with them this good news of God's love.

One of the most important and natural ways of witnessing is through established relationships with loved ones (family, friends, relatives, work associates, etc.) who do not know Christ. Motivated by a sincere desire for the best interest of a person, whether friend or stranger, one seeks to establish a friendly relationship by various means (socializing, meeting a felt need, or voluntary acts of kindness) without looking to obtain a reward from the person in return. Yet, in time, one seeks the opportunity to share a friend (Christ) with a friend.

Hopefully, this experience of friendship evangelism is available to every member 
of the community of faith. Throughout this witnessing experience, the pastor can encourage, demonstrate, and equip believers to model this life of service. Working together as ministers of Christ; friendship evangelism is a way of life in growth and development in Christ. It becomes a life of loving service generated from a personal caring fellowship with God and for others resulting in the salvation of the lost. 
CHAPTER 3

\section{REVIEW OF FRIENDSHIP WITNESSING THROUGH RELATIONSHIPS}

This chapter surveys and examines six selective programs currently being used to equip lay persons in friendship evangelism. The content of each program is analyzed and reviewed. Personal evaluations are given.

\section{Current Friendship Evangelism Programs}

Brief background information about each program is given. Program content reveals the various degrees of adaptability for usage in the local church context. The evaluations contain information relative to the strengths and weaknesses of each seminar.

\section{ACN Presents Friendship Evangelism}

\section{Background Information}

Adventist Communication Network (ACN) sponsored a live satellite Training Workshop on Friendship Evangelism, which was held September 9, 1995, at Berrien Springs Village Seventh-day Adventist Church and was uplinked across North America. Ed Schmidt, Associate Director of the North American Evangelism Institute, and Debra Brill, Associate Director of the Pacific Union Church Resource Center, led out in this two hour event. Copies of this video-taped event and the training handouts are available through AdventSource at 1-800-328-0525. 


\section{Program Content}

The ACN Presents Friendship Evangelism program is designed to teach disciples five steps in making friends for Christ: (1) Pray and Identify Where God is Leading; (2) Make Plans and a Commitment; (3) Make Deposits and Turn Acquaintances into Friends; (4) Create a Profile of Your Friend, and (5) Introduce Them to Christ.

Pray and Identify Where God is Leading. Invite God to purify your motives and lead you as you seek to share Christ with others. Intentionally review your own "world of people and places" for establishing friendships. Your circle of influence includes immediate family and close friends, those in your workplace and social circles, and casual acquaintances.

Make Plans and a Commitment. Write your commitment on a calendar or card. State why befriending a person for Jesus is important to you. Note specific people and dates you plan to make contacts. Work to turn acquaintances into friends.

Make Deposits and Turn Acquaintances Into Friends. Deepen your friendships by cultivating transparency, dare to talk about your affection (or appreciation for the other person), learn appropriate gestures of love. Also, make "deposits" into your friendship "bank account" by attending to little things, using reflective listening, being interested in the other person's interests, and making the other person feel important.

Create a Profile of Your Friend. Write up a short profile of your friend. Consider the person's interests and needs. Ask yourself, "How can Christ fulfill this person's needs?" Also ask, "What story would my friend benefit from hearing?" and "How does he or she feel about religion?" Consider a good phrase that will challenge them to follow Jesus. 
Introduce Them to Christ. When sharing the truth about Jesus Christ, begin with Jesus. Describe Christ personally by sharing what He has done in your life. Then share what it means to be a Christian to you. Use illustrations to depict your separation from God because of sin, and how Christ brings us back to God through the cross which bridges the gulf.

The program has a video instructional presentation that accompanies the participant handout materials. The video serves as the instructional resource that can be viewed as an entire first training session or as introductory material for each of the five steps promoted by the program. ${ }^{1}$

\section{Evaluation}

The ACN-Training Workshop on Friendship Evangelism program contains excellent detailed information on making friends for Christ. The participant handouts are easy to follow with visual aids and the format is designed for structured participation. The two facilitators approach is designed to emphasize and clarify the major points of emphasis which intentionally foster discussion. The program emphasizes the relational component by providing rehearsed audience demonstrations of real life situations. The audience is encouraged to write down questions because the opportunity would be provided at the end of the session for questions and answers. The program asks the participants to fill out an evaluation form for feedback.

Several weaknesses of the program are evident. There is too much information to

'All information regarding the ACN-Training Workshop on Friendship Evangelism program is derived from the video and participant handout materials of the September 9, 1995 session held at the Berrien Springs Village Seventh-day Adventist Church. 
make applicable in one lengthy two-hour session. There is minimal interaction between the facilitators and the audience concerning the information. The facilitators lectured too much. The lectures are scripted and staged, which made the presentations awkward and clumsy at times. The program fails to incorporate a structured field experience component or break- out sessions. Finally, the program provides no opportunity for the participants to test the concepts the facilitators have discussed in the instructional phase.

\section{Becoming a Contagious Christian}

\section{Background Information}

The Becoming a Contagious Christian training course was developed in 1995 primarily by Mark Mittelberg, the executive vice president of the Willow Creek Association in charge of evangelism, Lee Strobel, a teaching pastor at Willow Creek Community Church, and Bill Hybels, the senior pastor and cofounder of Willow Creek Community Church, in South Barrington, Illinois. The training course is the outgrowth of the celebrated book, Becoming a Contagious Christian, coauthored by Bill Hybels and Mark Mittelberg, which focuses on relational evangelism. Mittelberg, Strobel, and Hybels desired to develop a plan to equip every believer of the Willow Creek Church for personal evangelism. The focus of the training course is to equip believers for effective evangelism in their own style in today's world. The training course is designed to show ordinary believers how to share the Gospel in a natural and powerful way while being the person God made him or her to be (emphasis is placed on the individual' style of witnessing). The training course is a proven success because thousands have been 
equipped to do personal evangelism with a relational approach. ${ }^{1}$

\section{Program Content}

The Becoming a Contagious Christian training course can be presented using a variety of proposed formats depending on the size of the groups (from small groups with four to nine or large groups with 50 to 150 ). The various formats suggested are: four sessions of two hours each; eight sessions of one hour each; one, two, or three-day retreats; or adapt it to fit the needs of your local church.

The materials included are: video, overhead masters, leader's guide, and participant's guide. The video vignettes highlight each session's topic in snapshots using mainly everyday people in the ordinary places of real life settings (from fitness center to home setting to model relational evangelism). The overhead masters are provided for making the necessary transparencies. The leader's guide is thorough and easy to use. At one glance, the leader can view the notes and narrative, timed activity, outline overview of content; objective for each lesson, corresponding page in the participant's guide, and appropriate overhead transparency. The participant's guide provides an easy-to-use, hands-on means of identifying and developing an evangelism style that is effective for the participant.

The training course is designed for each session's exercises, discussions, selfassessments, and video vignettes to give step-by-step guidance to help participants become effective communicators for Christ. There is a section included with everyday answers that will help believers respond to difficult questions regarding Christianity.

${ }^{1}$ Mark Mittelberg, Building a Contagious Church (Grand Rapids, MI: Zondervan Publishing House, 2000), 12, 21. 
The eight-session course material is as follows: (1) Why Become a Contagious

Christian?; (2) Being Yourself; (3) Building Relationships; (4) What's Your Story?; (5)

What's His Story?; (6) Crossing the Line; (7) Putting It Together, and (8) Objection!

\section{Evaluation}

The Becoming a Contagious Christian training course is thorough, comprehensive, flexible, and adaptable. The participant receives classroom instruction, video vignettes that model the one-on-one techniques participants practice with each other in a safe environment, and field experience. Both the leader and the participant manuals are well designed and informative. The discussions, evaluation, and self-assessment forms help the participants to become confident in effectively sharing Christ with others. Each participant is equipped with the necessary skills to communicate the Gospel in his or her own style in an everyday setting.

The Becoming a Contagious Christian is one of the best equipping programs reviewed. It is powerful and attractive with user friendly materials. The course material is practical and helpful. The variety of opportunities provided for the participant to hear, view, and experience the witnessing component in a natural, normal way is very effective for building confidence in the participant. The program receives feedback from the participants who fill out training course evaluation forms in order to improve the future training programs.

The training course can be improved by providing an instructional video for the course leader. Otherwise, a person can see why the training course is successful in equipping thousands in relational evangelism. 
Making Friends for God

\section{Background Information}

Making Friends for God is a training course that was developed in 1990 by Mark Finley, one of the most prolific evangelists in the Seventh-day Adventist church ${ }^{1}$, along with Dan and Karen Houghton, project directors of Hart Research Center located in Riverside, California. The training course is designed to help pastors or facilitators/leaders equip the church members in making friends for Christ. The training course, with its primary focus on relational evangelism, presents practical help and materials tried and tested over the years of evangelistic success experienced by Pastor Finley. The materials are presently sold at the local Adventist Book Centers throughout North America. The program is a primary resource for pastors and churches across the North American Division. The training course is endorsed for use throughout the North American Division of the Seventh-day Adventist Church by the NAD Materials and Marketing Committee.

\section{Program Content}

The Making Friends for God program is very practical. The training course is designed for the Christian who wants to develop the skills needed to effectively witness in relational evangelism. The format is structured with a presentation, discussion and sharing time, role play, and interaction with the Word. The resource materials include:

'Pastor Mark Finley currently holds the position of Field Secretary for Evangelism at the General Conference of Seventh-day Adventists, headquartered in Silver Spring, Maryland. Pastor Finley presently serves as the Director of "It is Written," the celebrated religious television series, shown weekly around the world. Pastor Finley is credited with winning thousands of persons to Christ. 
instructional video, leader's guide, and participant's guide. The leader's guide is provided with additional information to supplement the material in the participant's guide. The information includes an outline of content with stated goals for each session, time management for the session, activities for one-on-one role play, and comments to emphasize during discussion sharing. The participant's guide is user friendly. Each session is one and a half hours in length and follows a regular structured format to include forty-five minutes for a video presentation, fifteen minutes for review, ten minutes for role-playing session, and twenty minutes for interaction with the Word.

The five-session course material discusses:

Session I Making Friends-We do not win our enemies to Christ. The only people we win are our friends.

Session II Conversational Evangelism-The purpose is to develop the Spiritimparted skill of sensitivity in detecting "open doors" of opportunity for Jesus in our casual conversations.

Session III Building Bridges-The goal is to share with the class a few simple methods of how to capitalize on peoples' questions in order to lead them into Bible studies.

Session IV Sharing the Word-The purpose is to clearly present the three basic steps in giving Bible studies: (1) Presenting Jesus first; (2) Revealing truth gradually; (3) Making regular appeals.

Session V Prayer Power-The power of effective soul-winning is the power of prayer.

\section{Evaluation}

The Making Friends for God program is thorough and comprehensive. The course is very practical and Pastor Finley's video presentation is clear and precise. The instruction is delivered with compassionate feeling. The participant receives classroom instruction, role-play activities in a safe environment, and field experience. Both the 
Leader and the Participant guides are well-designed and informative. Each participant is expected to develop practical skills for relational witnessing in daily life situations.

The format needs to be more flexible and adaptive. The pastor/leader's options are dictated by the video presentation. The course would be improved with a video demonstration of the role-play activities by people in real-life situations. Some of the research material is out-dated (the guides were published in 1989). Overall, the principles for making friends are timeless, yet, there needs to be more of an emphasis on the "howto" skills of making friends. There is no room for continued improvement because the course seeks no feedback from the participants or pastor/leader.

\section{The Caring Evangelism Course}

\section{Background Information}

The Caring Evangelism training course was developed in 1992 by William J. McKay and his evangelistic team at Stephen Ministries, in St. Louis, Missouri. The course is designed to show all Christians how to joyfully, comfortably, and naturally live and share the love of Jesus with others. This program has been field tested. William J. McKay is a pastor, author, teacher, and nationally known speaker. Pastor McKay serves as Director of Caring Evangelism for Stephen Ministries. He has led dozens of Caring Evangelism Workshops, teaching Caring Evangelism to thousands of pastors and lay persons. The course was designed to help congregations return to the biblical model of evangelism — everyday evangelists sharing Jesus with friends, relatives, coworkers, and students as a normal part of daily life. ${ }^{1}$

${ }^{1}$ McKay, 1. 


\section{Program Content}

The Caring Evangelism course is designed to equip Christians to communicate Jesus Christ to others through word and deed. The course is centered on the needs of others. The Caring Evangelism course is designed to fulfill seven goals:

a. The course must equip Christians to live and share Christ's love more fully so that others will be attracted to Jesus.

b. The course must be practical.

c. The course must be suitable for all Christians, not just a specially chosen, gifted, or motivated few.

d. The course must incorporate quality caring skills.

e. The course must be usable again and again by congregrations.

f. The course must enable lay leadership.

g. The course must be effective across denominational lines.

The Caring Evangelism course consists of sixteen one-hour modules, broken

down into two segments: (1) six modules that evangelize the evangelists, and (2) ten modules that focus on building evangelism skills. The six modules that evangelize the evangelists include:

1. Our Prodigal God-The participants begin to understand the Good News of Christ's love.

2. The One Most Important Thing-The participants better understand why people turn away from God's love and how people turn to "false gods" in place of God.

3. The Failure of Our False Gods-The participants learn three stages of selfunderstanding that individual people pass through as they come to see their need for a Savior.

4. Returning Home to God-The participants experience God's welcoming love at a deeply personal level. 
5. A Place to Belong, A Place to Become-The participants recognize the value of being connected to Christ through Christian community.

6. Go and Make Disciples-The participants learn how to help others through the evangelism process that the participants have just experienced.

The ten modules that focus on building evangelism skills include:

1. Putting the Care in Caring Evangelism-The participants are given a chance to practice relating in a process-oriented manner.

2. How to Build an Evangelizing Relationship-The participants learn the value of evangelizing within an authentic relationship.

3. Listening: The Most Important Evangelizing Skill-The participants practice the basic skills of reflecting content and feelings.

4. How to Uncover the "God-Sized" Needs of Others-The participants learn to use "listening for understanding" and witnessing to help others discover a need for a Savior.

5. The Problem, the Power, and the Promise-The participants are equipped with working knowledge of the message of salvation.

6. Discovering Your Own Good News Story-The participants remember and share a portion of their experience of God's love.

7. The Three Elements of an Effective Witness-The participants develop a clear and simple explanation of the biblical story of salvation.

8. Prayer Empowered Evangelism - The participants learn the skills of praying for and with others.

9. Putting It All Together-The participants follow the progress of a hypothetical relationship from beginning to end.

10. Everyday Evangelism - The participants plan how they will utilize what they have learned to evangelize others.

The Caring Evangelism course has four tools: the Leader's Guide, the Administrative Handbook, the Participant's Manual, and the book, Me, an Evangelist? Every Christian's Guide to Caring Evangelism.

The format is flexible and adaptable for two-day weekend retreats or for eight, 
two and half hours sessions to sixteen, one hour sessions. The course can accommodate various sizes and also includes promotional materials.

\section{Evaluation}

The Caring Evangelism course is the most thorough and comprehensive program reviewed. The course is practical and designed to equip the participant with the skills necessary to share the Gospel with others in a normal daily routine. The Caring Evangelism course seeks to reshape the participant's relationship with God in order to shape the participant's witness of God. The instructional methods are diverse and creative (using group discussion, brainstorming, hypothetical situations, skill practice, lecture, imagination exercises, verbatims, independent work, and reading assignments). The Caring Evangelism course seeks to obtain a commitment from the participant for attendance at all the sessions. Moreover, the course seeks feedback from the participants after each session. The promotional materials emphasize the benefits of the course to the participants. The marketing materials include media notifications, bulletin inserts, posters, and telephone contacts.

The Caring Evangelism course demands a great deal of time for preparation and planning on the part of the leaders and participants. A demonstration video would help the leader facilitate class lectures and model role-playing skills.

Witnessing Through Your Relationships

\section{Background Information}

Witnessing Through Your Relationships is a course developed in 1994 by the Lay Institute for Equipping (LIFE). The course is an adaptation of the Building Witnessing 
Relationships training process offered by the Personal Evangelism Department of the Home Mission Board (HMB) of the Southern Baptist Convention. ${ }^{1}$ The Witnessing Through Your Relationships program is coauthored by Jack R. Smith, the associate director of the Personal Evangelism Department at the HMD of Southern Baptist Convention, and Jennifer Kennedy Dean, an author, speaker, and conference leader. The principles in the Witnessing Through Your Relationships course were born from the personal experiences of Pastor Smith in seventeen years as a home missionary in Pennsylvania. $^{2}$

\section{Program Content}

Witnessing Through Your Relationships is a twelve-week study of how to develop trustful relationships with lost persons who are not immediately receptive to the gospel. The course teaches both witnessing and relationship-building skills. A participant is assigned to a small group. The group members are asked to sign a covenant of commitment to mutual accountability and support. The participant is provided a five-tier support network: (1) the group leader; (2) the training partner; (3) the discipleship group; (4) the group member's family, and (5) Jesus.

The course requires individual study of from thirty to sixty minutes a day, five days a week for twelve weeks along with the participant's attendance at thirteen weekly two-hour group sessions. Each group will have at least one leader, whose primary role is to facilitate and encourage. The leaders are to be role models and catalysts for learning.

${ }^{1}$ In 1997, the HMB became the North American Mission Board.

${ }^{2}$ Jack R. Smith and Jennifer Kennedy Dean, Witnessing Through Your Relationships (Nashville, TN: LifeWay Press, 1994), 4. 
The format allows for flexible group meeting places. Each group session includes the sections "Before the Session," "During the Session," and "After the Session." The resource materials include a Leader's Guide and a Participant's Manual. The Leader's Guide provides administrative guidance, training aids, and learning activities for conducting a small-group study. Additionally, 12-unit sessions are provided. They are: (1) Foundations for Developing Witnessing Relationships; (2) Becoming a Complete Witness; (3) Testing the Soil; (4) Sowing Seeds in Good Soil; (5) Sowing Seeds in Rocky Soil; (6) Sowing Seeds in Thorny Soil; (7) Sowing Seeds in Hard Soil; (8) Developing a Witnessing Strategy; (9) Preparing the Soil; (10) Cultivating Witnessing Relationships; (11) Developing Skills and Disciplines for Witnessing, and (12) Understanding the Holy Spirit's Role in Witnessing.

The benefits of completing the Witnessing Through Your Relationships course include helping the participant to: (1) define his or her circle of witnessing influence; (2) evaluate a lost person's receptivity to the gospel; (3) develop a trustful relationship that enhances the receptivity of a lost person; (4) start a witnessing conversation in a natural, non-threatening way; adapt his or her witness to a lost person's level of receptivity; (5) present his or her testimony and share the good news, and (6) develop witnessing skills.

\section{Evaluation}

The Witnessing Through Your Relationships training course is an intense and thorough, equipping program. The course demands a high level of commitment on the part of the participant, group members, and the group leader. The commitment involves time, study preparation, and participation on the part of all group members. The covenant helps to foster a high sense of accountability for group assignments, individual 
assignments, and confidentiality in the group sessions. The Witnessing Through Your Relationship training course is designed especially for adults. The course activities include one-on-one and group dynamics which foster trust and openness by the participant.

The Leader's Guide and Participant's Manual are informative and practical. Both guides are step-by-step user-friendly. The materials assume the participants have at least a high school education level.

The Witnessing Through Your Relationships course limits the participants to adults with a high school level education. A demonstration skills video would aid the modeling process for the group leader and participants. The program depends heavily on the facilitation skills of the group leader. A lack of facilitation skills by the group leader could prove disastrous for the participants. The effectiveness of the course could be limited if a personal crisis affects a participant's time commitment to personal study or group activities.

\section{Friend2Friend}

\section{Background Information}

Friend2Friend was developed by Curtis Rittenour, a church growth consultant, and Monte Sahlin, a researcher, administrator, pastor, and teacher for the Seventh-day Adventist church. The program was newly released in fall of 2000. The Friend2Friend course is designed to introduce principles of friendship evangelism to every church member. It is a fresher approach to friendship evangelism than previously modeled in the Friendship Evangelism Seminar Kit developed by Monte Sahlin in 1988. Monte Salhin, primary author, has shared the field-tested concepts for over a dozen years. 


\section{Program Content}

The Friend2Friend program is a workshop to teach every church member about the principles of friendship evangelism. The program emphasizes a five-step paradigm of mingling, showing sympathy, ministering to needs, winning trust, and inviting people to follow Jesus. The program is designed to be implemented by a facilitator and an assistant who leads a group format. The leaders initiate interest, present information, coach experimentation, and promote personal application.

The course materials include a Leader's Guide for the facilitator and assistant which provides all the materials needed to lead a group. Other resource tools are a Participant's Guide, promotional materials, video instructional tapes, power point slides, and overhead transparencies.

Friend2Friend provides a flexible format. The program can be conducted as part of a weekend training, a Sabbath school class, prayer meeting, or small group meeting. Friend2Friend has six sessions: (1) Why Friendship Evangelism?; (2) Mingling With Others; (3) How to Show Compassion; (4) Ministering to People's Needs; (5) Winning Confidence, and (6) Follow Me.

Each session is broken into four parts:

1. Touch-The primary role of the facilitator is to motivate;

2. Teach-The primary role of the facilitator is to teach;

3. Try-The primary role of the facilitator is to coach;

4. Treasure-The primary role of the facilitator is to cheerlead.

Each session lasts about ninety minutes. The Touch, Try, and Treasure segments take about twenty minutes each. The Teach segment takes about thirty minutes. 


\section{Evaluation}

The Friend2Friend training course is designed to expose the participant to principles of friendship evangelism in a practical method. The participants receive a variety of learning techniques and skills from the group activities and one-on-one roleplaying. Both the Leader's and Participant's guides are well-designed and informative. The format for holding different sessions is flexible and adaptable to the local churches needs. The resource tools are helpful aids and offer the latest technological assistance. Friend2Friend provides excellent principles of friendship evangelism to the participants.

The effectiveness of the training course can be greatly hampered by the wrong selection of a facilitator and assistant. A lack of good teaching, coaching, or cheerleading skills by the facilitator and assistant could hinder the participant's ability to comprehend and apply the principles of friendship evangelism correctly. The course needs more howto demonstrations of implementing the friendship principles.

\section{Summary}

The role of the pastor in equipping lay persons to do the work of ministry is well defined in scripture. The pastor's primary responsibility involves providing leadership to the local congregation in many respects like a sports coach. The pastor's main objective is to engage each member in the work of ministry. The effectiveness of a local congregation in ministry is manifested when members are encouraged to work together utilizing their individual skills, talents, and spiritual gifts for the benefit of others under the pastor's coaching. The equipping role of the pastor represents a paradigm shift away from the traditional role of the pastoral model. In the traditional model the pastor is the "star," the care giver, the primary person that makes friends, and brings people to the faith. In the 
traditional model the members mainly encourage the pastor to do the work of ministry. In the non-traditional model, congregational care, support, and friendship evangelism are the primary responsibilities of the members. The pastor empowers the congregation to do the work of friendship evangelism. Pastors equip the members as they engage in ministry. Pastors and members become full partners in ministry. Pastors must be careful to resist the ego satisfaction that they derive from meeting the needs of others without the assistance of members and focus on the members doing ministry and leading friends to Christ.

Six friendship evangelism programs were reviewed. Each program emphasizes equipping members to make friends and bring people to Christ. Each program includes the two essential elements of classroom instruction format and individual participation (related to real life situations) necessary to empower others to do friendship evangelism in the context of daily living. The most comprehensive program reviewed is the Caring Evangelism course.

Four friendship evangelism programs that were reviewed but not included with an in-depth analysis were Winsome Witnessing ${ }^{1}$, The Way of the Master Basic Training Course ${ }^{2}$, The NET Evangelism for the $21^{\text {st }}$ Century ${ }^{3}$, and Friendship First ${ }^{4}$. Each program has a different emphasis for usage in the local church.

'Gary Gibbs, Winsome Witnessing (Modesto, CA: Nike, 2003).

${ }^{2}$ Kirk Cameron, and Ray Comfort, The Way of the Master Basic Training Course (Bartlesville, OK: Genesis Publishing Group, 2002).

${ }^{3}$ North American Mission Board, The NET Evangelism for the $21^{s t}$ Century (Alpharetta, GA: NAMB, 2000).

${ }^{4}$ Karl Leuthauser, ed., Friendship First (Loveland, CO: Group Publishers, 2005). 
Winsome Witnessing was designed by Gary Gibbs. Gibb's program includes a book and three VHS tapes with twelve half-hour programs. He illuminates useful how-to instruction with inspiring and humorous stories from his own witnessing adventures. Gibbs shares simple skills to lead people to Christ, real-life practical information, and proven strategy to give interesting Bible studies. The program can be used in group or individual setting.

The Way of the Master Basic Training Course was developed by Kirk Cameron and Ray Comfort. The eight-session course is specially formatted to train believers in a group setting to simply and confidently share the gospel with family, friends, and strangers. The authors teach the trainee how to witness through fascinating on-the-street conversations with gang members, atheists, cult members, intellectuals at different locations. The program's kit contains four DVDs and CDs, a study guide, quick reference card, gospel tracts, printable bulletin inserts and poster, and certificate.

A team of pastors, church leaders, and seminary professors designed The NET Evangelism for the $21^{\text {st }}$ Century training course. The NET is designed to assist churches in training believers to effectively do evangelism in our changing culture. Believers are trained to communicate the gospel to different people in a postmodern world. The course equips Christians to tell their story in a very natural and biblical way. The NET works for churches of all sizes and is adaptable to any ministry style. The program's kit contents include a mentor handbook, an apprentice manual, leader guide, gospel tract, teaching video, and powerpoint $\mathrm{CD}$.

Friendship First is new church-wide program. The course is designed for a small group get-together which includes a six week sermon series to unite the congregation and 
thirteen weeks of small group get-togethers for children, youth, and adults. The goal of the program is to give the church a deeper relationship with Jesus; a genuine culture of community; practical friendship skills; daily challenges for loving others; a fun approach centered on food; and easy formats to fit any ministry need or setting. A variety of kits have been developed for children, youth, and adults. 


\section{CHAPTER 4}

\section{DESIGN AND IMPLEMENTATION OF THE PROJECT}

This chapter identifies how the Friendship Evangelism Seminar was organized and implemented in the Bladensburg Seventh-day Adventist Church. Information regarding the contextual background, Friendship Evangelism Seminar background, seminar objectives, and seminar content are outlined. Details regarding the enrollment, participation in the project, classroom instruction, field work, and evaluation components of Climbing Friendship Mountain Seminar are reviewed.

\section{Organization of the Seminar}

This section has a brief description of the Bladensburg Church and demographic information about the community is provided. Information relative to the background of the Friendship Evangelism Seminar design is given.

\section{Contextual Background}

Upon my arrival in May of 1993, the Bladensburg Seventh-day Adventist Church was a predominately African American congregation (yet a diverse group representing over five countries) located one mile east of the northeast quadrant of the District of Columbia in the township of Bladensburg, Maryland. Church attendance was one hundred and fifty members. Most of the congregation was composed of single young professional adults (ages 17-35) mainly female. The largest group of young people were 
children (ages 3-10). Church leadership was composed of an equal amount of males and females, mainly young adults and adults. Overall the church members had good social relationships. Each week members would gather in different homes to have social events. The church leaders' relationships were fragmented over concerns related to the lack of finances and vision for the church.

No ministry or leadership training existed within the membership. Church ministries were limited to only a few traditional ones (Sabbath School, Community Services, Adventist Youth, Church Choir, Elders, Deacons, Deaconess, Ushers, and Personal Ministries). Spiritual nurturing of the congregation was limited to Sabbath morning worship service and Wednesday night prayer meeting. Community outreach consisted of giving out food baskets to needy families at Thanksgiving and Christmas seasons. Public evangelism was restricted to the annual fall week of prayer. Baptisms averaged about ten annually.

After a few months of assessments and much prayer, the church board developed a mission and vision statement. The ministry strategies and church finance were coordinated with the church vision acrostic, "REAP" (Reach the unchurched, Equip the members for ministry, Assimilate new members, and Proclaim the gospel). The pastor started leadership training. A few months later, the church established several new ministries (Pathfinders, Adventurers, Youth Ushers, Children's Choir, and Young Adult Ministries). The church was organized into community outreach and church membership visitation. Baptisms rose to an average of twenty to thirty converts annually. In summer of 1995, the church conducted a tent meeting which resulted in twenty-five converts.

Church numerical growth led to relationship problems among the membership. 
The single young adult group continued to increase, but many of them felt disconnected from meaningful relationships within the church. Half of the singles believed the church catered fo the young married couples and their families. Some of the single young adults threaten to transfer their membership to other area churches. Church conflict emerged, yet the church recognized its responsibility to provide ministry primarily, but not exclusively, to the African American community in Bladensburg and surrounding metropolitan area.

Bladensburg is a diverse community with a population of 463,240 within a five mile radius of the township. ${ }^{1}$ The African American population is 321,952 , representing 69.5 percent of the total population. The median age of the total population is 35.9 years. The population by gender is 52.5 percent female and 47.5 percent male. The marital status of the total population is 36 percent married and 64 percent single. The martial status of the total female population is 38.5 percent never married, 28.1 percent widowed/divorced/separated, and 33.4 percent married. The martial status of the total male population is 39 percent married, 45 percent never married, and 16.1 percent widowed/divorced/separated. The total households, consisting of one or more persons who live together in the same housing unit, regardless of their relationship to each other are 171,172 . The family households are 108,174 . The census reveals that 80 percent of the housing units were built before 1970, with 92.9 percent of the housing units occupied. The median home value is $\$ 120,975$. The median household income is $\$ 45,170$. The employment status of persons 16 years and older is 375,717 . Of the totaled employed workers, 64.4 percent are white collar workers and 18.9 percent blue collar workers. Over

\footnotetext{
${ }^{1}$ The 1990 US Census data, updated to reflect 2000 estimates, is the source for the demographic information provided.
} 
half the total workers commute to work using their own transportation, while another 25 percent use public transportation and another 16 percent carpool. The normal unemployment rate for the total population is 4.6 percent. The average years of school completed is 12.5 years.

The demographic data indicate a long-established, diverse community with lower middle class, well-educated, mobile, and urban. Two-thirds of the population is single. Females make up slightly more than half of the total population, and slightly less than 40 percent of them have never been married. Another third of the female population has been widowed/divorced/separated. Males make up slightly less than half of the population, and 45 percent of them have never married. Another 16 percent of the males has been widowed/divorced/separated.

The large single population of the Bladensburg church and community suggests that friendship evangelism would be a blessing to both groups. Andy Stanley and Charles Willits write, "We are a culture craving relationship. In the midst of our crowded existence, many of us are living lonely lives. We live and work in a sea of humanity, but we end up missing out on the benefits of regular, meaningful relationships." Loneliness is common among women, it has reached epidemic portions among men. A survey reveals that 90 percent of the male population in America lack a true friend. ${ }^{2}$ Most people will not admit to being lonely, but two-thirds of Americans say that having close relationships

${ }^{1}$ Andy Stanley and Charles Willits, Creating Community (Sisters, OR: Multnomah Publishers, 2004), 24.

${ }^{2}$ John Ortberg, Everybody's Normal Till You Get to Know Them (Grand Rapids, MI: Zondervan, 2003), 29. 
with other people is always on their minds. ${ }^{1}$ Even though church members live in a large city, work at a successful company, attend Bible study, have many acquaintances, they feel alone. ${ }^{2}$ Friendship evangelism provides the pastor an opportunity to equip the members of the church, especially singles, to develop meaning friendships while seeking to lead others to Christ.

\section{Friendship Evangelism Seminar Background}

The Friendship Evangelism Seminar was developed to enable members to identify, understand, and form various friendships within the church fellowship and establish friendships with non-members that lead a friend to a personal relationship with Christ. Before this can happen, however, members and the pastor must be on one accord. Effective evangelism is accomplished when the pastor and members engage in ministry together. In order to establish this partnership between pastor and members for evangelism at the Bladensburg Church, and interest survey was developed and given to two hundred members during worship service one Sabbath morning (appendix C). Results from the eight-four interest surveys returned indicated members had a strong desire to learn friendship evangelism. Many (43\%) believed friendship evangelism to be the most effective type of evangelism and nearly half expressed that the primary type of evangelism that helped them become a member at Bladensburg Church was friendship evangelism. In addition to forming a partnership in evangelism, several members expressed the desire to form closer friendships within the church fellowship. Thus the

${ }^{1}$ Les Parrott and Leslie Parrott, Relationships (Grand Rapids, MI: Zondervan, 1998), 13.

${ }^{2}$ Stanley and Willits, 24. 
idea for a seminar focused on friendship evangelism was developed.

The seminar was designed to help increase the number of members in all age groups who desire to make and lead friends to Christ. Also, the seminar would provide those pastors who are active in evangelism but who are uncomfortable with training, a user-friendly model for equipping members in friendship evangelism.

\section{Friendship Evangelism Seminar Design}

Interested persons from the Bladensburg and District of Columbia metropolitan area, Allegheny East Conference churches participated in the seminar. Participants learned how to identify, understand, and form friendships within and without the church fellowship. Participants also learned how to share Christ with friends.

The seminar, Climbing Friendship Mountain, was conducted in the main sanctuary of the Bladensburg Church each Wednesday night for six weeks. It consisted of sermons, classroom instruction, and field work experience. Each seminar session lasted for an hour and thirty minutes. [Two separate Sabbath worship sermons ran for an hour each]. Before participating in the seminar, attendees signed a personal commitment sheet (appendix D) and those who successfully completed the training, by regular attendance and during the field work, received a certificate. Participants formed new friendships within the church fellowship and with other non-believers. Some even successfully led friends and relatives to the faith, which resulted in baptism.

\section{Climbing Friendship Mountain Seminar}

In this section seminar objectives are identified. The seminar course outlines is provided with information relative to the objectives of each sermon and session. 


\section{Seminar Objectives}

The seminar was designed to equip the participants in effective friendship evangelism. The seminar objectives were: (1) to identify, understand, and form friendships, (2) to expose the participants to concepts and practical techniques of effective friendship evangelism, (3) to provide a context for participants to practice developing friendships, and (4) to prepare participants to effectively share Christ with their friend.

\section{Course Outline}

The Climbing Friendship Mountain Seminar consisted of two sermons and six sessions. One sermon was conducted before the first session, and the second sermon was conducted after the six sessions. Each session included lesson objectives, instruction, class participation, and summary. The participants engaged in field work assignments beginning with Lesson 3.

The first sermon, titled "What is a Real Friend?," introduced the need for authentic friendship. The sermon content focused on the friendship between Jonathan and David in 1 Samuel 18. The sermon material was designed to meet the following five objectives: (1) to share with the participants the need for a real friend, (2) to highlight the characteristics of a real friend, (3) to make the participants aware of the different types of friendships, (4) to introduce the participants to a real friend, Jesus Christ, and (5) to introduce and invite the participants to the Climbing Friendship Mountain Seminar. The objectives were achieved by sermon presentation, audience response to sermon content, and a verbal commitment to attend the seminar.

The first session, titled "A Need for Friendship Evangelism," was designed to meet the following objectives: (1) to share with the participants the purpose and 
objectives of the seminar, (2) to provide participants with an general overview of the seminar, (3) to highlight the need for friendship evangelism, (4) to briefly reexamine the biblical basis for friendship evangelism, and (5) to obtain a commitment from the participants to the seminar process. The objectives were achieved by lesson presentation, group discussion, a commitment contract form that each participant was asked to complete, and a summary of the main points discussed.

The second session, titled "Four Levels of Friendship Evangelism," was designed: (1) to review the need for friendship evangelism, (2) to introduce the concept design of Climbing Friendship Mountain, and (3) to give the participants an overview of four types of friendships in the Bible. The objectives were achieved by the lesson presentation, group discussion, and summary of the main points discussed.

The third session, titled "How to Make Check-Out Friends," was designed to achieve the following objectives: (1) to help the participants identify and understand "check-out" friendships, (2) to examine the biblical evidence for "check-out" friendships, and (3) to assist the participants in forming "check-out" friendships. The objectives were achieved by the lesson presentation, the class participation exercise, and summary of the main points discussed. The participants were asked to practice forming "check-out" friendships at least once a day as homework.

The fourth session, titled "How to Make Choice Friends," had the following aims: (1) to review "check-out" friendships, (2) to help the participants identify and understand "choice" friendships, (3) to examine the biblical evidence for "choice" friendships, and (4) to assist the participants in developing "choice" friendships. The objectives were achieved by the group discussion, lesson presentation, the class participation exercise, 
field work feedback, and summary of the main points discussed. The participants' homework assignment was to identify a "choice" friendship and be involved in at least one activity with a "choice" friend during the week.

The fifth session, titled "How to Make Close Friends," was designed: (1) to review both "check-out" and "choice" friendships, (2) to help the participants identify and understand "close" friendships, (3) to examine the biblical evidence for "close" friendships, and (4) to expose the participants to opportunities to form "close" friendships. The objectives were achieved by group discussion, lesson presentation, the class participation exercise, field work feedback, and summary of the main points discussed. The participants were asked to contact at least one "close" friend and express gratitude for the friendship and to look for opportunities each day to establish a "close" friendship before the next session.

The sixth session was titled "How to Introduce People to Your Best Friend." This final session was designed with the following objectives: (1) to review the previous forms of friendships, (2) to help the participants identify and understand "best" friendships, (3) to examine the biblical evidence for "best" friendships, (4) to expose the participants to opportunities to introduce a friend to their "best" friend, Jesus Christ, and (5) to have the participants evaluate the seminar. The objectives were achieved by group discussion, field work feedback, lesson presentation, summary of the main points discussed, and presentation of certificates of completion to the participants. The participants were asked to practice the concepts shared about friendship and to bring a friend to church the following Sabbath.

The second sermon, titled "I Thought But Now I Know," was designed to 
incorporate all of the four levels of friendships in one message while leading a friend to Christ. The sermon content focused on the friendships formed between Namaan, the little girl, Namaan's wife, the king of Israel, the soldiers under Namaan's command, the servant of the prophet, and the prophet. The ultimate friendship is making Christ one's "best" friend. At the end of the sermon, an opportunity was given for the members of audience to make Christ their "best" friend. The objectives were achieved by sermon presentation, audience response to sermon content, members bringing friends to church, and friends accepting Christ as their "best" friend.

\section{Enroliment of Participants}

This section contains information about the registration process, promotional materials, and consent forms used. Feedback is given from the participants relative to their homework, fieldwork, group discussion, and class exercise assignments. Statistical information is given about the participants involved in the project along with their evaluations of the seminar.

\section{Registration for the Seminar}

An invitation to register for the Climbing Friendship Mountain Seminar was made available to the members of the Bladensburg Seventh-day Adventist Church. Each member received a promotional flyer and information sheet regarding the objectives of the seminar. The members were free to invite participants from the surrounding churches in the metropolitan area of Allegheny East Conference churches. The bulletin clerk of the church was asked to place an announcement in the bulletin for consecutive weeks beginning at least one month before the start of the seminar. Pre-registration forms (see 
appendix E) were made available to the members. Those who pre-registered were assessed a $\$ 3$ fee for materials. Those who did not pre-register were assessed a $\$ 6$ fee for materials. Thirty-three persons registered for the program with twenty-eight of those preregistered. All thirty-three persons were present at the start of the program.

\section{Consent to Participate in the Seminar}

The primary objective of the project was to equip the participants in effective friendship evangelism using the concepts and principles taught in the Climbing Friendship Mountain Seminar. A secondary purpose for the seminar was to fulfill requirements of the Doctor of Ministry degree. The participants were advised at the start of the seminar of the dual purpose of the seminar. Each participant signed a consent statement (appendix F) indicating his or her full knowledge of the purpose of the seminar and commitment to continue the seminar.

\section{Participation in the Seminar}

The participants were all baptized Seventh-day Adventists holding membership in the Bladensburg and District of Columbia metropolitan area churches of the Allegheny East Conference. A breakdown of the registration information indicated that there were twenty-three participants from Bladensburg, Maryland, eight from Ft. Washington, Maryland (Breath of Life Church), and two from the District of Columbia (Dupont Park Church). There were eleven males and twenty-two females who started the program. Thirty of the participants received a certificate for successfully completing the Climbing Friendship Mountain Seminar by regular attendance and active participation. 


\section{Classroom Instruction}

The Climbing Friendship Mountain Seminar was conducted at the Bladensburg

Seventh-day Adventist Church in Bladensburg, Maryland. Sessions were held on

Wednesdays, for six weeks, beginning October 5, 1999. Sessions were one hour and thirty minutes in duration.

The seminar classroom instruction involved several teaching techniques which incorporated lectures with the aid of Power Point presentations and flip chart demonstrations, plus small group discussion and exercises. The majority of participants explained that the clear, expressive manner and style in which the facilitator delivered the lecture helped their understanding of the information given. Each session began with sign-in, review of the previous lesson, and an overview of the current lesson with stated objectives to be accomplished. Participants' lessons were issued for each session that corresponded closely to the lecture outlines (see appendix $\mathrm{G}$ for copies of the lecture outlines). Considerable time was allotted to address questions and concerns. Participants readily engaged in lively class discussions and small group exercises. Participants expressed constant appreciation for practical biblical insights and the information given and received. After each session, a number of participants stayed after class to continue the discussion on the night's topic. The sessions that generated the most discussion and significant response were session 2 , a lesson on how to identify and understand the four types of friendships, session 4, a lesson on how to identify, understand, and build choice friendships, and session 5, a lesson on how to identify, understand, and build close friendships. A number of participants expressed that a right understanding between choice and close friendships helped to resolve unrealistic expectations in previously 
strained relationships with friends. Overall attendance was excellent. Homework assignments were completed on time and generated excellent feedback. Each participant demonstrated more confidence initiating friendships by the end of the seminar.

Participants expressed that the seminar enhanced their ability to naturally witness in the context of everyday life.

\section{Field Work}

The field and homework assignments were designed: (1) to provide participants with practical experience in friendship evangelism, (2) to develop more confidence in relational witnessing, (3) to capitalize on opportunities to develop existing friendships, (4) to build significant new friendships, and (5) to share Christ with a friend. In session 3 participants practiced developing friendships, and in session 6 participants practiced sharing Christ with a friend.

The follow-through of the practice sessions was field work assignments. During the week between sessions, participants were requested to utilize the concepts and skills learned in the classroom setting to build friendships in multiple. life situations whether at home, in the workplace, in transit between different places, or in the community where the person lives.

The field work assignments provided opportunities for valuable feedback, review, and clarification of witnessing activities at the next session. The field work experience proved a confidence booster for each participant in building new friendships and developing established friendships. Participants were more willing to meet and greet individuals they did not know previously in a variety of settings. Several participants conveyed that they were more relaxed and comfortable in sharing Christ with a friend. 
The field work assignments provided the necessary reinforcement for of skills and concepts for participants. Additionally, the field work provided the proper environment to make the transition from knowledge of friendship skills and concepts to personal application.

\section{Evaluation of the Project}

Twenty-six participants who finished the Climbing Friendship Mountain Seminar completed a written evaluation of the program. The evaluation tool measured three main areas: (1) demographics of participants, (2) the presentation of materials, and (3) the effectiveness of the program (see appendix $\mathrm{H}$ ). The demographics focused on age, gender, and church affiliation. The presentation of materials surveyed preparedness of presentation, the pace of materials covered, and the effectiveness of the instructor. The evaluation of the program focused on what the participants gained from the seminar. Participants were asked to indicate whether they would recommend the seminar to others. The participants also were requested to indicate what should have been added and to give additional comments. The evaluation consisted of eleven questions. Three questions addressed the demographics, four questions about the presentation, and four questions addressed the overall effectiveness of the seminar. The evaluation results appear as an attachment to appendix $\mathrm{H}$.

The evaluation results indicate the following pertinent information. The demographic composition of the participants who completed the written evaluation were eleven males and fifteen females. The breakdown of the age range of the participants were: (1) five participants between the ages of 18-35 years, (2) eleven participants between the ages of 36-50 years, (3) five participants between the ages of 51-65 years, 
and (4) five participants over 65 years. All participants were members of the Seventh-day Adventist Church. Twenty-five participants indicated that the presentation was wellprepared and the materials were covered at a good pace for understanding. The seminar was considered by one participant to be "not prepared" and "too slow." The instructor's facilitation of the seminar and interaction with the participants had a very positive effect on the vast majority of participants. One participant indicated the instructor had "too little or no extent" motivated his knowledge about friendship evangelism. Twenty-five participants acknowledged they had learned "a lot." Only one participant responded "nothing" was learned. No participant was reluctant to recommend the seminar for others. None of the participants offered suggested changes for the seminar. The participants provided the following comments regarding the most useful aspects of the seminar:

1. "The seminar information was adaptable and relevant"

2. "Understanding the true meaning of friendship"

3. "The ease of application once the levels of friendships are addressed"

4. "The way it opens one's awareness of true friendship and it various levels"

5. "The necessity of different types of friends"

6. "The personal realization of having a variety of friends - social, very close, etc."

7. "More friendships were formed as discussion occurred"

8. "Members sort friends among membership"

The following additional comments were made:

1. "It was instrumental in Breath of Life members organizing friendship circles." 
2. "We have shared what we learned from the seminar with friends, family members, and business associates. The knowledge has blessed and enlightened them. Hurry and copy write material. Please write a book!"

The comments of the participants reveal that three of the four objectives of the seminar were realized immediately. The participants were able to identify, understand, and form friendships. Concepts and practical techniques of friendship evangelism are being applied to daily life situations. The participants from the Breath of Life Church have organized friendship circles. The final objective of leading a friend to Christ was realized about three months later as members from the Bladensburg and Breath of Life churches formed friendships and through these friendships have lead family and friends to Christ.

The effects of friendship evangelism still exist in the Bladensburg Church today. Bladensburg Church is known in the community and among area churches for its spirit of compassion and hospitality. The church membership has befriended the community and its officials. Once per month the Pàstor attends a community pastoral and lay council to discuss social and religious issues that affect the citizens of the community. The Pastor has initiated relationships with the township officials. John Moss, the police chief, visits the church annually to check on the congregation and inform the church about citizens who need their assistance. David Harrington, the councilman, regularly attends church services, and assisted the church in purchasing a home next door to the church. The councilman noted their involvement in the community. The computer program that the church operates to help the citizens improve their computer skills for job opportunities, and assist students with their homework. The growing Hispanic population around the 
church benefits from the ten week English as a second language program. Thirty families with three to four persons per family have attended consistently. The church visits the community nursing home once per month to encourage its residents. Bladensburg church has established two ministries to mentor teenagers (Sisters for Christ and Soldiers for Christ). These organizations include community teenagers and leaders. Both groups run a feeding program for the community. 


\section{CHAPTER 5}

\section{SUMMARY AND CONCLUSIONS}

This chapter provides a summary of the main concepts explored in chapters 1,2 , and 3. Conclusions and recommendations for further study and improvement of the project as they pertain to chapters 4 and 5 are suggested. Remarks and reflections are also given.

\section{Summary}

Friendship evangelism has been the Lord's approach to reaching the lost with the gospel since the fall of Adam and Eve in the garden of Eden. Friendship evangelism is first modeled in the one-on-one context of a friend (the Lord) reaching out to save friends (Adam and Eve) in a crisis with the ultimate goal of sharing Christ. Adam and Eve, being the first recipients of the gospel of Christ, told people in the antediluvian world about their promised Savior Friend, Jesus Christ.

God continued the personal approach of friendship evangelism through His covenant relationship with Noah, Abraham, Moses, the nation of Israel, and the prophets in the Old Testament. The ultimate purpose of the Lord's covenant relationship with Israel involved developing an intimate friendship with Israel to share Christ with the surrounding nations.

The friendship evangelism approach was used extensively by Jesus, the Master 
Evangelist, throughout His ministry to reach others. The early church also made use of friendship evangelism to generate rapid membership growth for Christ.

The primary purpose of the church is to share the gospel of Christ. The friendship evangelism approach has many advantages. A friendship approach is flexible and adaptable to any situation or circumstance. Friendship evangelism personalizes the gospel suitable for the occasion. It affords the excellent opportunity to break barriers to witnessing about Christ in a non-threatening method. Friendship evangelism is inclusive. Friendship evangelism allows each member to establish deeper friendships and foster new relationships while witnessing about Christ. It can be used independently or in conjunction with other types of evangelism. Friendship evangelism helps to build greater team ministries in the local church. It opens more opportunities for more members of all ages, genders, and skills to engage in the personal work of reaching the masses with the gospel. Friendship evangelism allows every member called by God for service to fulfill the biblical mandate to bring others to faith.

The writings of Ellen G. White emphasized the necessity of friendship evangelism. White strongly declared the responsibility of every member to become actively engaged in winning people to faith. White pointed out the advantages of a loving, kind friend in breaking barriers to help a person in need and to lead that person to Christ. She spoke about the social aspects of evangelism which need to be cultivated in the members to help take advantage of witnessing opportunities in the daily life experiences. White felt strongly that the role of the pastor was to model and to teach the members how to befriend others and to increase the members' awareness of witnessing through effective training. 
White's writings agree with the New Testament concept of the pastor and laity working together as partners in ministry. The roles of the pastor and the laity in the partnership are different. The pastor's primary responsibility is to equip the members to do the work of ministry. The pastor is to help access and to develop the spiritual gifts of the members. The pastor must model before the members the skills and concepts that he or she wishes the members to possess and emulate. Once the spiritual gifts of each member are identified, the pastor must encourage the members to work together as a team in utilizing their gifts to win others.

In friendship evangelism the pastor models before the members how to be a loving and kind Christian while equipping the members with the skills and concepts of being a friend in order to lead a friend to Christ. The pastor's example of praying, encouraging, equipping, and befriending the members will lead the members to follow his or her spiritual leadership. The members will accept this partnership in ministry and embrace the opportunity to develop existing friendships while cultivating new friendships. The members become conscious of the opportunities that exist daily in sharing Christ with a friend. The pastor and members are less stressed and burdened because ministry becomes a way of life.

The friendship evangelism programs reviewed for this project all concurred with the role of the pastor and members working together as partners in ministry. Each program was designed with the premise that each member must learn the skills and concepts necessary for cultivating friendships with unreceptive persons in order to share the gospel of Christ. The programs provide the pastor with instructional material to help equip the members to share their faith. Each program utilizes the components of 
classroom instruction and participant participation exercises in life related context. The programs are all designed to enhance friendship evangelism skills of the participants.

\section{Conclusions}

The Climbing Friendship Mountain Seminar program shared with thirty-three participants at the Bladensburg Seventh-day Adventist Church affirms the importance of identifying, understanding, and forming friendships to lead others to Christ. The project emphasized the necessity of each member's responsibility in sharing Christ with others. The project provided a model of pastor/teacher as equipper of the members to do the work of making friends for Christ.

The design of the project combined the essential elements of the existing friendship evangelism programs reviewed. Implementation of the project confirmed the importance of pastor as equipper, classroom instruction and participation, and field work experience. Participants were taught how to identify, understand, develop established friendships, and form new friendships that can lead to opportunities for sharing Christ. The project exposed the participants to the conscious reality that exists each day to form a friendship and share Christ with a friend. The positive evaluations received, the new friendships formed, old friendships developed, friendship circles established, influence of participants to secure opportunities for the seminar to be shared at four elementary schools and three churches, Allegheny East Conference workers meeting and elders retreat, and the Regional Conference Wives session at Oakwood College, and the fact that several participants were able to lead a friend to Christ affirms the contribution of the Climbing Friendship Mountain Seminar program and the validity of the project. 


\section{Recommendations}

Although the project made a valuable contribution in assisting the participants in cultivating new friendships, developing existing friendships, and sharing Christ with a friend, there are several recommendations that are suggested. The first recommendation has to do with the interest survey and evaluation materials. The friendship evangelism interest survey could be revised to measure the demographics, interest, skills, and experience of potential participants in the area of making friends and leading friends to Christ. This information would make planning presentations and marketing promotional materials to a particular group very effective. The evaluation survey would measure the effectiveness of the skills and concepts learned by the participants which would include the demographics, presentation of information, and material distributed during the seminar. This information gathered would aid the presenter in making necessary improvements to keep future seminars relevant.

Based on the interest survey, promotional materials for various interest groups, such as Sabbath School classes, small ministry groups, and the worship services could also be developed. A weekly timetable for the release of the promotional materials would be developed. The promotional process should be increased from one month to a threemonth period. The bulletin announcements at least one month prior to the first meeting is sufficient. An extended promotional time would allow for more adequate time for potential participants to make plans to attend and allow for momentum within the organization to build among registered participants.

The written materials of the seminar should be updated to present the concepts in a more attractive appearance and keep information relative to the targeted participants 
user-friendly. New resource materials especially related to interpersonal communication and group dynamics should be identified and added. The written materials could utilize the inclusion of cartoons or graphs to illustrate different concepts with a variety of colors so that they are more attractive to the reader. Additionally, a formatted disc of the Power Point presentation, along with videotapes, cassettes, and DVDs of the sessions should be made available to the participants and others for further learning and distribution. The services especially of the youth and young adults could be incorporated in this process to engage them in the partnership of ministry.

Another recommendation would involve keeping the seminar limited to one faith community within an organization. The advantages to the limited approach within an organization include: (1) developing new friendships, (2) creating caring work . relationships, (3) enhancing ministry effectiveness, and (4) cultivating more effective team ministry units. The pastor/presenter has the added advantage of knowing the strengths and weaknesses of the participants. This allows the pastor/presenter to tailor the material to meet the particular needs of the participants more efficiently.

Also noted or change involves keeping the breakout work groups within the sessions to no more than twelve participants. Those participants would operate within the same working units throughout the seminar to increase the opportunities to form new friendships and cultivate existing friendships. Group bonding experiences can develop more effectively within smaller groups of four to six participants.

Additionally, developing a variety of time frame formats for the seminar is strongly recommended. Active participants would be more likely to commit to a weekend or week seminar. The seminar sessions should continue within the framework of sabbath 
worship services. The flexible and adaptable options should increase the possibility for increased attendance.

The final recommendation would involve adding a celebration event at the conclusion of the seminar. The participants would be provided with written invitations to distribute to family members, friends, and business associates. The participants would receive certificates at the end of the event. The participants could make remarks to introduce their invited guests and affirm the existing friendships or new bonds. The event would inspire the participants to continue to form friends and lead friends to Christ. Ultimately, the guests present would be motivated to participate in the next seminar and encourage others to participate as well. The event would also allow the members opportunities to befriend guests.

Implementation of the recommendations suggested above will enhance the effectiveness of the Climbing Friendship Mountain Seminar program, and serve to make an already effective ministry tool even better.

\section{Personal Reflections}

The process of accomplishing this project has been one of the most enlightening experiences in my life and ministry. It has afforded me the opportunity to gain greater insights into identifying, understanding, and forming new friendships. The project provided me the opportunity to develop a more natural and comfortable way of sharing my love for Christ with others.

Friendship evangelism is a non-threatening and comfortable lifestyle of evangelism which combines a genuine love for Christ with a love for people. Friendship 
evangelism helps the members to understand how to cultivate friendships with nonreceptive people. Members with a working knowledge of how to form friendship are more confident and relaxed in meeting, befriending, seeing, and assisting others in need without fear of being rejected. This style of evangelism allows more members regardless of their spiritual gifts, temperaments, or ministries to believe that they can participate in sharing their love for Christ with others.

The concepts and skills learned from the Climbing Friendship Mountain Seminar program will continue to assist members to identify, understand, form, and cultivate friendships with conscious knowledge of daily opportunities to share Christ's love with a friend. Some friendships renewed will be strengthened and other friendships formed will last the person a lifetime. 
APPENDIX A

EXAMPLES OF PERSONAL EVANGELISM

IN THE NEW TESTAMENT 


\section{THIRTY-FIVE EXAMPLES OF JESUS ENGAGING IN PERSONAL EVANGELISM}

1. Jesus call to discipleship for Andrew, John, and Peter (John 1:35-42)

2. Jesus call to discipleship for Phillip and Nathaniel (John 1:43-51)

3. Jesus personal dialogue with Nicodemus (John 3)

4. Jesus and the woman of Samaria (John 4)

5. Jesus and the nobleman (John 4:46-54)

6. Jesus and the call of Simon, Andrew, John, and James (Luke 5:1-11)

7. Jesus and the leper (Mark 1:40-45)

8. Jesus and the paralytic (Mark 2:1-12)

9. Jesus and the call of Matthew (Mark 2:13-17)

10. Jesus and the man at the pool of Bethesda (John 5)

11. Jesus and the man with the withered hand (Luke 6:6-11)

12. Jesus and the centurion (Luke 7:1)

13. Jesus and the widow of Nain (Luke 7:11-17)

14. Jesus and a sinful woman (Luke 7:36-50)

15. Jesus and the Gadarene demoniac (Mark 5:1-20)

16. Jesus and Jairus (Mark 5:21-43)

17. Jesus and the woman with an issue of blood (Mark 5:22-34)

18. Jesus and the two blind men (Matthew 9:27-31)

19. Jesus and the demoniac (Matthew 9:32-34)

20. Jesus and the Syrophenician woman (Matthew 15:21-28)

21. Jesus and the deaf and dumb man (Mark 7:32-37) 
22. Jesus and the blind man near Bethsaida (Mark 8:22-26)

23. Jesus and the demoniac boy (Mark 9:14-29)

24. Jesus and the woman taken in adultery (John 8:1-11)

25. Jesus and the three would be disciples (Luke 9:51-62)

26. Jesus and the lawyer (Luke 10:25-37)

27. Jesus and the man born blind (John 9)

28. Jesus and the woman who was bent over (Luke 13:10-21)

29. Jesus and the rich young ruler (Matthew 19:16-22)

30. Jesus and the blind man near Jericho (Mark 10:46-52)

31. Jesus and Zacchaeus (Luke 19:1-10)

32. Jesus and Judas Iscariot (Luke 22; John 13; Matthew 27)

33. Jesus and Pilate (John 18; 19; Luke 23)

34. Jesus and Herod (Luke 23; Mark 15)

35. Jesus and the two thieves (Luke 23:32-43)

\section{FIFTEEN EXAMPLES OF PERSONAL EVANGELISM IN THE BOOK OF ACTS}

1. Peter and John with the lame man (3:1-11)

2. Philip with Simon the sorcerer (8:9-24)

3. Philip and the Ethiopian eunuch (8:26-40)

4. Ananias and Saul of Tarsus (9:10-19)

5. Peter with Aeneas and Dorcas (9:32-42)

6. Peter with Cornelius (10:1-11:18)

7. Paul with Elymas (13:6-12) 
8. Barnabas and Saul with Sergius Paulus (13:17-32)

9. Paul and Silas with Lydia (16:12-15)

10. Paul and Silas with the Philippian jailer (16:23-40)

11. Paul's house to house evangelism in Ephesus (20:17-35)

12. Paul with Felix and Drusilla (24:24-27)

13. Paul with king Agrippa (Chapter 26) Note that Paul personalized his appeal.

14. Paul with Publius and his father (28:7-11)

15. Paul in his own hired house in Rome for two years $(28: 16-31)$

List taken from: Delos Miles, Master Principles of Evangelism (Nashville: Broadman Press, 1982), 11. 
APPENDIX B

A PARTIAL LIST OF FRIENDSHIPS IN THE BIBLE 


\section{A PARTIAL LIST OF FRIENDSHIPS IN THE BIBLE}

1. Abram and Lot (Genesis 14, 18, 19)

2. Abraham and God (Genesis 22; James 2:23)

3. Moses and God (Exodus 3;33:7-23)

4. Moses and Aaron (Exodus 4:13-31)

5. Moses and Joshua (Exodus 24:12-18; Numbers 27:18-23)

6. Naomi and Ruth (Ruth 1:1-22)

7. Jonathan and David (1 Samuel $18,19,20,23)$

8. David and Friends (2 Samuel 15:13-37)

9. David and Hushai (2 Samuel 15:32-17:29)

10. Elisha and the Shunammite Woman (2 Kings 4:8-44; 8:1-6)

11. David and the Mighty Men (1 Chronicles 11:1-47)

12. Job and His Three Friends (Job $2: 1-13 ; 6: 1-7: 21 ; 8: 1-22$ )

13. Jeremiah and Baruch (Jeremiah 36:1-32)

14. Ebed-melech the Ethiopian and Jeremiah (Jeremiah 37:1-38:28)

15. Jesus and the Paralytic (Matthew 9:1-8)

16. Four Friends (Mark 2:1-12)

17. Philip and Nathanael (John 1:45,46)

18. Jesus and Nicodemus (John $3 ; 7: 32,50-52$ )

19. Peter and His Friends (Acts 12:1-25)

20. Paul and His Friends (Acts $13: 13 ; 15: 36-40$ )

21. Paul and the Believers in Ephesus (Acts 20:17-38)

22. Paul and Onesimus (Philemon 1:8-25) 
APPENDIX C

INTEREST SURVEY AND RESULTS 


\section{Interest Survey}

\section{A. Demographics}

1. Age Range: $18-35$ $36-50$

$51-65$ $65+$

2. Gender:

Male

Female

3. Church Member

Visitor

\section{B. Questions}

1. Which type of evangelism are you most interested in learning?

Friendship Public Small Group Other

2. Which type of evangelism do you believe to be the most effective?

Friendship Public Small Group Other

3. Which type of evangelism helped you become a member of the Bladensburg

Church?

Friendship Public Small Group Other

4. Do you have more friends among:

Bladensburg Church Family \& Relatives Other

5. Do you have any friends who left the church within the past two years?

None 1-2 3-4 $5+$

6. Which relationships in your life were helpful in leading you to faith in Jesus? Family Pastor Friend Neighbor Other

7. If your friends decided to leave your church, how important are your friendships to you staying a member of the Bladensburg church?

I would leave I would go with my friends I would consider leaving I will stay 
8. When you see a friend getting baptized does it make you consider:

Baptism

Re-baptism

Neither

9. When seeing your friends doing evangelism does it motivate you to do evangelism? (Door to door, visitation, handing out tracks, giving bible studies, etc.)

Yes __ No 
Age Group: 18-35

\begin{tabular}{|l||l|l|l|l|l|}
\hline Ques: 1 & Friend & Public & Group & Other & \\
\hline $\mathrm{f}$ & 11 & 1 & 5 & & \\
\hline $\mathrm{m}$ & 2 & & 4 & & \\
\hline Ques: 2 & Friend & Public & Group & Other & \\
\hline $\mathrm{f}$ & 11 & 2 & 4 & & \\
\hline $\mathrm{m}$ & 1 & & 3 & & \\
\hline Ques: 3 & Friend & Public & Group & Other & \\
\hline $\mathrm{f}$ & 5 & 3 & & 9 & \\
\hline $\mathrm{m}$ & 1 & & 2 & 2 & \\
\hline Ques: 4 & Bladensburg & Family & Other & & \\
\hline $\mathrm{f}$ & 4 & 10 & 3 & & \\
\hline $\mathrm{m}$ & 1 & 3 & & & \\
\hline Ques: 5 & None & $1-2$ & $3-4$ & $5+$ & \\
\hline $\mathrm{f}$ & 10 & 4 & & 2 & \\
\hline $\mathrm{m}$ & 2 & 1 & 1 & & \\
\hline Ques: 6 & Family & Pastor & Friend & Neighbor & Other \\
\hline $\mathrm{f}$ & 11 & 5 & 5 & 2 & 1 \\
\hline $\mathrm{m}$ & 4 & 4 & 1 & & \\
\hline Ques: 7 & Leave & Go/friends & Cons/leave & Stay & \\
\hline $\mathrm{f}$ & 2 & & & 14 & \\
\hline $\mathrm{m}$ & & & & 4 & \\
\hline Ques: 8 & Baptism & Re-baptism & Neither & & \\
\hline $\mathrm{f}$ & 3 & 5 & 7 & & \\
\hline $\mathrm{m}$ & 1 & 2 & 1 & & \\
\hline Ques: 9 & Yes & No & & & \\
\hline $\mathrm{f}$ & 11 & 5 & & & \\
\hline $\mathrm{m}$ & 4 & & & & \\
\hline
\end{tabular}


Age Group: $36-50$

\begin{tabular}{|l||l|l|l|l|l|}
\hline Ques: 1 & Friend & Public & Group & Other & \\
\hline f & 12 & 4 & 7 & 1 & \\
\hline $\mathrm{m}$ & 1 & 1 & 1 & & \\
\hline Ques: 2 & Friend & Public & Group & Other & \\
\hline $\mathrm{f}$ & 12 & 4 & 8 & & \\
\hline $\mathrm{m}$ & 1 & 1 & 1 & & \\
\hline Ques: 3 & Friend & Public & Group & Other & \\
\hline $\mathrm{f}$ & 13 & & 2 & 9 & \\
\hline $\mathrm{m}$ & 1 & & 1 & & \\
\hline Ques: 4 & Bladensburg & Family & Other & & \\
\hline f & 9 & 8 & 6 & & \\
\hline $\mathrm{m}$ & & & 1 & & \\
\hline Ques: 5 & None & $1-2$ & $3-4$ & $5+$ & \\
\hline $\mathrm{f}$ & 11 & 9 & 2 & 2 & \\
\hline $\mathrm{m}$ & 1 & 1 & & & \\
\hline Ques: 6 & Family & Pastor & Friend & Neighbor & Other \\
\hline $\mathrm{f}$ & 15 & 8 & 5 & & 3 \\
\hline $\mathrm{m}$ & 2 & 1 & & & \\
\hline Ques: 7 & Leave & Go/friends & Cons/leave & Stay & \\
\hline $\mathrm{f}$ & & 1 & & 23 & \\
\hline $\mathrm{m}$ & & & & 2 & \\
\hline Ques: 8 & Baptism & Re-baptism & Neither & & \\
\hline f & 2 & 8 & 12 & & \\
\hline $\mathrm{m}$ & & & 2 & & \\
\hline Ques: 9 & Yes & No & & & \\
\hline $\mathrm{f}$ & 15 & 6 & & & \\
\hline $\mathrm{m}$ & 2 & & & & \\
\hline
\end{tabular}


Age Group: 51-65

\begin{tabular}{|l|l|l|l|l|l|}
\hline Ques: 1 & Friend & Public & Group & Other & \\
\hline $\mathrm{f}$ & 10 & 4 & 1 & & \\
\hline $\mathrm{m}$ & 1 & 1 & 1 & & \\
\hline Ques: 2 & Friend & Public & Group & Other & \\
\hline $\mathrm{f}$ & 12 & 4 & 2 & & \\
\hline $\mathrm{m}$ & 2 & 1 & 2 & & \\
\hline Ques: 3 & Friend & Public & Group & Other & \\
\hline $\mathrm{f}$ & 10 & 2 & 2 & 3 & \\
\hline $\mathrm{m}$ & 3 & 1 & 1 & & \\
\hline Ques: 4 & Bladensburg & Family & Other & & \\
\hline $\mathrm{f}$ & 5 & 13 & 1 & & \\
\hline $\mathrm{m}$ & & 1 & 2 & & \\
\hline Ques: 5 & None & $1-2$ & $3-4$ & $5+$ & \\
\hline $\mathrm{f}$ & 15 & 1 & & & \\
\hline $\mathrm{m}$ & 3 & & & & \\
\hline Ques: 6 & Family & Pastor & Friend & Neighbor & Other \\
\hline $\mathrm{f}$ & 12 & 7 & 5 & & 1 \\
\hline $\mathrm{m}$ & 2 & 1 & & & \\
\hline Ques: 7 & Leave & Go/friends & Cons/leave & Stay & \\
\hline $\mathrm{f}$ & & 2 & & 13 & \\
\hline $\mathrm{m}$ & 2 & 1 & & & \\
\hline Ques: 8 & Baptism & Re-baptism & Neither & & \\
\hline $\mathrm{f}$ & 1 & 3 & 10 & & \\
\hline $\mathrm{m}$ & & & 3 & & \\
\hline Ques: 9 & Yes & No & & & \\
\hline $\mathrm{f}$ & 14 & 2 & & & \\
\hline $\mathrm{m}$ & 3 & & & & \\
\hline
\end{tabular}


APPENDIX D

PERSONAL COMMITMENT CONTRACT 
Name

Church

Signed

Date

I understand that the "Climbing Friendship Mountain Seminar" is a six week process, and I believe the Lord is directing me to commit myself to:

1. Attend two Sabbath worship services and six sessions

2. Participate in class and field instruction

3. Complete assignments

4. Prepare through prayer and personal study

5. Share with another person what I learn in class within 24 hours 
APPENDIX E

PRE-REGISTRATION FORM 


\section{PRE-REGISTRATION FORM}

FOR THE SEMINAR

\section{"CLIMBING FRIENDSHIP MOUNTAIN"}

INSTRUCTOR:

BEGINNING DATE:

ENDING DATE:

TIME:

LOCATION:

REGISTRATION FEE:
Pastor Marcellus T. Robinson

October 6, 1999

November 10, 1999

Wednesday's 7:00 p.m - 8:30 p.m

Bladensburg Seventh-day Adventist Church $410554^{\text {th }}$ Street

Bladensburg, MD 20710

$\$ 3.00$ for materials

$\$ 6.00$ for those who do not pre-register

Please fill out and forward to the Bladensburg Seventh-day Adventist Church. Attention Church Secretary. For further information you can call (301) 277-5911.

YOUR NAME

YOUR ADDRESS

YOUR PHONE

(H) (W)

YOUR CHURCH

FOR OFFICE USE ONLY

Date Registration Received: Date Registration Paid: 
APPENDIX F

STATEMENT OF CONSENT 


\section{STATEMENT OF CONSENT}

To be a part of a Doctor of Ministry Project

in conjunction with pursuing the seminar

"Climbing Friendship Mountain"

I hereby grant Pastor Marcellus T. Robinson, to use as he determines the need in the pursuit of his Doctor of Ministry Project, any information I have produced to date, and any information I will produce in partial fulfillment of the requirements of the seminar, "Climbing Friendship Mountain."

Furthermore, I give consent to fulfill specific requirements of this seminar as they relate to the design of the doctoral project as directed by Pastor Marcellus T. Robinson.

Date Signed:

Signature of Participant

Date Signed: 
APPENDIX G

CLIMBING FRIENDSHIP MOUNTAIN

SERMON AND SEMINAR OUTLINES 
Introduction:

Gale Sayers, the greatest runner in the National Football League from 1965-1969, and Brian Piccolo of the Chicago Bears are the first black and white players to be roommates in the history of the National Football League. Gale Sayers makes an appearance on the Ed Sullivan Show in New York City (after receiving the George Halas Award for being the Most Courageous Player in the National Football League early in the day). Brian Piccolo is dying of cancer in Chicago. With tears pouring down his face, Gale Sayers asks a national television audience to "pray for my friend, Brian Piccolo, the Most Courage Player in the National Football League."

What is a real friend? Read 1 Samuel 18:1-9.

I. A Real Friend is Committed. (1 Samuel 18:1-4)

A. Friendships are often formed out of a deep need in our lives.

1. Saul, Jonathan's father, is beginning to lose his power as king in Israel.

2. David saves Saul and the nation of Israel by killing the giant, Goliath.

B. Friendships are formed when one person takes the initiative to be a friend.

1. "The soul of Jonathan was knit to soul of David." (1 Sam. 18:1, NASB)

2. "Jonathan loved him as himself." (1 Sam. 18:1, NASB)

3. "Jonathan made a covenant with David because he loved him as himself." (1 Sam. 18:3, NASB)

4. "Jonathan stripped himself of the robe that was on him and gave it to David, with his armor, even to his sword and his bow and his belt." (1 Sam. 18:4, NASB)

C. Friendships are formed when unconditional love is given.

1. Jonathan loved David unconditionally.

2. David had nothing to give Jonathan.

3. Jonathan never looked for anything in return for what he gave David.

4. Friends do not keep score. 
II. A Real Friend is Loyal. (1 Samuel 19:1-7)

A. Four reasons why friends become disloyal.

1. Someone you respect becomes disloyal to your friend.

2. Sometimes the crowd around you is disloyal (peer pressure).

3. Sometimes you will personally profit by being disloyal to a friend.

4. You are intimated to become disloyal.

B. Jonathan spoke well of David to Saul his father when he could have remained silent.

1. A person's character can be destroyed with the tongue.

2. A person's character can be destroyed sometimes when a friend remain silent an inappropriate time.

III. A Real Friend Communicates. (1 Samuel 20:1-4)

A. Disagreements will not stop communications with a friend.

B. Communication is easy when unqualified love is expressed.

IV. A Real Friend is Giving. (1 Samuel 23:16-18)

A. Jonathan gives David his blessing as next king of Israel.

B. Three months later Saul and Jonathan are killed in battle.

C. As long as Jonathan lived David never had an opportunity to show him gratitude for his friendship.

D. The natural response of friendship is to show gratitude to a friend.

E. David take care of Jonathan's cripple son, Mephibosheth. (2 Sam. 9:7)

V. Jesus Christ is a Real Friend.

A. Jesus is committed. (Romans 5:8)

B. Jesus is a communicator. (Genesis 3:9)

C. Jesus is loyal. (Matthew 26:39)

D. Jesus is giving. (John 3:16) 


\section{Introduction:}

I want you to imagine, if you please, that we are in Naaman's company. We are on our way to the prophet's house. We have just left the presence of the king of Israel. Naaman is a little bit hot under the collar. He is upset. You must understand, Naaman is accustomed to dealing with kings, one-on-one, face-to-face. He has no use for messengers or servants to the king.

Naaman's the captain of the king's men. He is a modern day Colen Powell, a mighty man of valor. He is the champ. He fears no man. He has won many fights.

I. Naaman has money, position, power, and family, but he has one problem, leprosy.

A. Leprosy can ultimately kill you.

1. Physically, it can destroy your body.

2. Socially, you can lose your family and friends because people are afraid of you.

3. Spiritually, you are conditioned not living right because you are under the curse of God.

B. Naaman's money, family, position, and power cannot help him with his one problem.

1. Most people have many problems.

2. People seek money, family, position, and power everyday to help them with their many problems.

3. But none of these can help Naaman with his one problem, leprosy.

II. Naaman needs help fast to save him from his one problem.
A. Who can help Naaman?
B. Who will help Naaman?
C. Naaman needs a friend to help him in his crisis.

III. There is one who can help Naaman, but she has been taken by him away from her family and friends against her will (Naaman's wife, servant girl).

A. The servant girl alone has the answer to his one problem. 
1. She is the only witness.

2. All she has to do is tells what she knows.

3. If she remains silent, he dies. (She gets vengeance.)

4. If she speaks and he obeys, he lives. (She gets justice, he gets mercy.)

5. What will she do?

B. The servant girl tells Naaman's wife the prophet in Israel can save Naaman.

1. Naaman probably would refuse the servant girl's advise directly coming from her.

2. The servant girl tells Naaman's wife in order for him to get the help he needs.

IV. Naaman seeks help from the king of Israel.

A. Everyone wants to go to the king's palace.

1. The way to the king's palace is fast, quick, and exciting.

2. The road to the king's palace is like the express interstate highway.

3. It is the scenic route with huge trees and beautiful flowers.

4. Read Matthew 7:13.

B. The king of Israel cannot help Naaman.

V. Naaman seeks help from the prophet of Israel.

A. No one wants to go to the prophet's house.

1. The road to the prophet's house is less traveled.

2. Few people travel this route.

3. The road to the prophet's house is a single lane, winding, narrow dirt road.

4. The route is lined with sticky thorns and thistles with weeds.

5. Read Matthew 7:14.

B. The prophet of Israel gives Naaman the answer to his one problem.

1. Naaman arrives at the prophet's house looking for some hospitally.

2. All Naaman receives from the prophet is the word of God deliver to him by the servant of the prophet.

3. The answer is simply, "Go, wash in the Jordan River seven times."

VI. Naaman's problem is deeper than his skin, but beneath the skin. 
A. Naaman is angry because things are not working the way he thought.

B. Naaman's greatest problem is his pride and arrogrance.

VII. Naaman obeys the words of God because of an encouraging friend.
A. Naaman's servant encourages him to obey the instructions of the prophet.
B. Naaman reluctantly obeys and dips in the Jordan River.
C. Naaman is healed.

VIII. Jesus is the answer to our one problem, sin.
A. We are reluctant to obey God's word.
B. We need a friend to encourage us to obey God's word.
C. If we obey God's word, we will be saved from sin.
D. Jesus is the best friend of the sinner. 


\section{CLIMBING FRIENDSHIP MOUNTAIN SEMINAR}

\section{SEMINAR LECTURE OUTLINES}

\section{SESSION ONE: “A NEED FOR FRIENDSHIP EVANGELISM”}

\section{PART ONE:}

Objectives: To provide participants with an overview of the seminar. To share with the participants the purpose and objectives of the seminar.

To obtain a commitment from the participants to the seminar process.

\section{OPENING REMARKS}

1. Call group together

2. Warm Welcome

3. Opening Prayer

\section{A. INTRODUCTIONS}

1. Instructor - Marcellus T. Robinson

2. Participants (name, church, why they wanted to attend the seminar)

\section{B. ADMINISTRATIVE ISSUES}

1. Registration Form

2. Review Personal Commitment Contract

3. Consent Form

C. SEMINAR OBJECTIVES

1. To teach the participants how to identify, understand, and form friendships.

2. To expose the participants to concepts and practical techniques of effective friendship evangelism.

3. To provide a context for participants to practice developing friendships.

4. To prepare participants to effective share Christ with a friend. 
D. SEMINAR EXPECTATIONS OF PARTICIPANTS

1. Attend all sessions (reiterate time, dates, and location, etc.)

2. Active participation

3. Understand, identify, and form friendships

4. Introduce a friend to Christ

5. Receive a Seminar Certificate

E. REVIEW REMAINING SEMINAR SESSIONS

Session 2 - Four Levels of Friendship Evangelism

Session 3 - How to Make Check-Out Friends

Session 4 - How to Make Choice Friends

Session 5 - How to Make Close Friends

Session 6 - How to Introduce People to Your Best Friend

PART TWO:

Objectives: To highlight the need for Friendship Evangelism.

To briefly examine the biblical basis for the need for Friendship Evangelism.

F. THE NEED FOR FRIENDSHIP EVANGELISM

1. What is the number one problem is America today? (Group Discussion)

a. Take a five minutes to discuss within your group.

b. List three of your suggested answers.

c. Share with all participants your answers.

2. Loneliness is the one problem in America today. (William Appleton, Harvard psychiatrist)
a. Loneliness has been described as the "disease of the decade." (Katherine Barrett)
b. Twenty-nine million Americans now live alone. (U.S. Census Bureau)
c. "Americans are among the loneliest people in the world. As many as one-third of us admit to frequent periods of loneliness." (George Gallop, Jr.)
d. Loneliness is the leprosy of modern society. (Mother Teresa) 
3. Nine suggestions to overcome loneliness according to William Appleton, Harvard psychiatrist)

a. Take note of all the people in your life. (Friends and acquaintances)

b. Contact at least one friend per day.

c. Identify your interest and act on them.

d. Ask yourself how long you have been feeling lonely.

e. Make time for your friendships.

f. Learn to separate your friends from acquaintances.

g. Expect to feel lonely at some time.

h. Get a pet.

i. Avoid things that compound your loneliness.

4. Six out of the nine suggestions to overcome loneliness relates to having a friend.

a. Two-thirds of Americans say that having close relationships with other people is always on their minds. (Chip Walker and Elissa Moses)

b. The number one reason college students seek counseling is for their relationships. (Bridget Murray)

c. Ninety percent of the male population in America lack a true friend. (John Ortberg)

d. No one wants to admit that they're lonely. Loneliness is something people associate with losers. (Jacqueline Olds, psychiatrist)

5. Lack of friendships is a matter of life and death.

a. As infants, we do not know or understand the subtle dynamics of relating and love, but our need for connection is already so strong that its absence impairs natural growth and development, even bringing on death. This profound and deep human need for nurturance does not change as we grow older. Not by a long shot. Adults who isolate themselves from the world, refusing so much as to own a pet, are likelier to die at a comparatively young age than those who cultivate companionship. (Drs. Les and Leslie Parrott)

b. Adults who do not cultivate nurturing relationships have premature death rates twice as high as those with frequent caring contact.

(Studies done at University of California at Berkeley)

c. The data indicates that social isolation is as significant to mortality as smoking, high blood pressure, high cholesterol, obesity, and lack of exercise. (James S. House of the University of Michigan)

\section{G. BRIEFLY EXAMINE THE BIBLICAL EVIDENCE FOR THE NEED FOR FRIENDSHIP EVANGELISM.}


1. What was God's original plan? (Review Gen 1-2)

a. "And God saw it was good." (Gen.1:4,10,12,18,21,25)

b. "It was very good." (Gen 1:31)

2. God is a relational being. (Gen 1:26)
a. God the Father
b. God the Son
c. God the Holy Spirit
d. One God--perfect oneness-yet three persons

3. God created man and woman for relationship with Him and each other.

a. Created man and woman in his own image. (Gen 1:27)

b. In a perfect world, God declared, "It is not good for man to be alone." (Gen 2:18)

c. God created us with a hunger for relationship-for relationship with Him and with our fellow people. At our very core we are relational beings. The soul cannot prosper without being connected to others. (Dr. Henry McCloud)

d. What is striking is that the Fall has not yet occurred. There is no sin, no disobedience, nothing to mar the relationship between God and man. The human being is in a state of perfect intimacy with God. Each word he and God speak with each other is filled with closeness and joy, he walks with God in the garden in the cool of the day. He is known and loved to the core of his being by his omniscient, Loved-filled Creator. Yet the word God uses to describe him is "alone." (John Ortberg)

e. We often talk about inside every human being there is a Godshaped void that no other person can fill. But, apparently, there is also a "human-shaped-void" in every person that God Himself will not fill.

No substitute will fill this need in you for human relationship. Not money. Not achievement. Not busyness. Not money, Not busyness. Not books. Not even God Himself. Even thought this man was in a state of perfection, he was "alone." and it was "not good." (Andy Stanley and Charles Willits)

f. Alone and isolated were never to be used to describe His children. It's not good because we were created with a deep need for rich and meaningful connection with other people. Without it, we don't reflect the image of the One who created us. And without it, bad things happen, like lost perspective, fear of intimacy, selfishness, and poor health. (Andy Stanley and Charles Willits)

g. A person's ability to love and connect with others lays the foundation for both psychological and physical health. This 
research illustrates that when we are in a loving relationship, a bonded relationship, we are growing. When we are isolated, we are slowly dying. (Dr. Henry Cloud)

h. "So God created man in his own image" (Gen 1:27). Just as God exists in meaningful relationship, so are we to exist in this quality of relationship as well. The need for it is part of our genetic makeup. God is a relational being and $\mathrm{He}$ created His prized creations, you and me, with the need for significant relationship as well. (Andy Stanley and Charles Willits)

\section{H. CLOSING}

1. Review the main points of the lesson.

2. Preview Session 2, "Four Levels of Friendship Evangelism"

3. Homework Assignment: Make a list of all the people in your life (friends and acquaintances). 


\section{SESSION TWO}

"FOUR LEVELS OF FRIENDSHIP EVANGELISM"

Objectives: To review the need for Friendship Evangelism

To give the participants an overview of the different types of friendships

To introduce the concept design of Climbing Friendship Mountain Seminar

\section{OPENING REMARKS}

1. Prayer and welcome

2. Review of Session One: "The Need for Friendship Evangelism"
A. THE COMPONENTS OF FRIENDSHIP EVANGELISM ARE REVEALED IN THE LORD'S COVENANT RELATIONSHIP WITH HIS PEOPLE IN THE OLD TESTAMENT.

1. The Lord seeks out Adam and Eve after the first sin.

a. "Where are thou?" (Gen 3:9)

b. The first messianic promise is given in the Bible that speaks of One who will break the power of Satan. (Gen 3:15)

c. Paul affirms the promise to our day. (2 Pet 3:9)

2. The Lord saves the human family through covenant relationship with Noah.

a. The Lord establishes His covenant with Noah. (Gen 6:18)

b. Rainbow sign is a reminder of God's grace and mercy. (Gen 9:817)

3. God's friendship with humanity is extended through His covenant relationship with Abraham.

a. God's "I will" promises to Abraham. (Gen 12:1-3)

b. God reaffirm His covenant relationship with Abraham as "the friend of God." (Gen 15:1-21)

c. God announces to Abraham that He will establish His covenant with the birth of Isaac. (Gen 17:1-14)

4. God's establishes His friendship with Moses and the nation of Israel.

a. Israel asked, "What is His name?" (Exod 3:13) 
b. "I AM THAT I AM" (Exod 3:14)

c. The Lord established His friendship with Israel by delivering Israel from the Egyptian bondage.

d. God's friendship is extended to all people through Israel. (Exod $6: 4-8$; Ps 106:45)

e. By choosing to be friends with God, Israel is allowed to enter a deeper relationship with $\mathrm{Hm}$ which other nations can only observe from a distance. (Exod 19:5; 24:7)

f. Evangelism among the nations was to be fostered through the covenant relationship with the Lord. (Exod 19:6; Deut 26:19)

g. Peter applies these same phrases, "peculiar treasure" and "holy nation," to the New Testament church with the same implications of evangelizing the world with the good news of Jesus Christ. (1 Pet 2:9)

h. The Lord expects the New Testament church to engage in evangelism with people through the believer's friendship with Christ.

\section{B. JESUS MODELED FRIENDSHIP EVANGELISM IN HIS DEALINGS WITH} PEOPLE.

1. Jesus accepted people in their different life situations.

a. Jesus reached people where they were. (John $1: 37,38$ )

b. Jesus touched people at their point of need. (John 2)

c. Jesus showed them love and compassion. (John 5)

d. Jesus gradually led them to Himself as their Savior and Friend. (John 4)

2. Friendship evangelism is the most effective approach to reaching people for Christ.

"Christ method alone will give true success in reaching people. The Savior mingled with men as one who desired their good. He showed His sympathy for them, ministering to their needs, and won their confidence. Then He bade them, 'Follow Me."' MH 143

a. Mingled with people

b. Showed compassion for them

c. Met them at their point of need

d. Gained their confidence

e. Ask them for a deeper level of commitment to friendship

3. A practical definition of friendship evangelism is: 
A Chrisitian who shares the gospel of Christ through a personal friendship with those whom one come in the contact in day to day life.

\section{HOW DO I IDENTIFY AND DEVELOP CLOSE FRIENDSHIPS?}

1. Pamela Reeve - Three Levels of Friendships

a. Acquaintances - "Friends along the way"

b. . Companions - "Friends for the hike"

c. Intimate Friends - "Friends for the journey"

2. Karol Ladd and Terry Ann Kelly - The Circle of Friendships
a. Acquaintances - Woman at well (John 4)
b. Good Friends - Lazarus, Mary, Martha
c. Soul Mates - Peter, James, and John

3. John Maxwell - Four Types of Friendship
a. Surface - The most common of all relationships
b. Structured - Built on routine encounters
c. Secure - Friendships are tested
d. Solid - Long-term relationships

4. Byron K. Hill - Seven Degrees of Friendshps
a. Acquaintances - Familiar strangers
b. Neighbor - Those who are nearby and willing to help
c. Confederates - Mutually dependent but rarely equal in power
d. Pals - Share social activities
e. Close Kin - Like family or they can be family
f. Co-workers or Roommates - Develop with effort put into relationships
g. Close Friends - Truest Friends, but few in number

5. Climbing Friendship Mountain — Four Levels of Friendship
a. Check-Out - Casual relationships
b. Choice - Social
c. Close - Companionship
d. Best - Intimate

\section{CLOSING}

1. Review main points.

2. Preview Session Three - "How to Make Check-Out Friends" 
3. Homework Assignment - From the previous list of friends and acquaintances start to identify what level of friendship exist and why. 
SESSION THREE

\section{"HOW TO MAKE CHECK-OUT FRIENDS"}

Objectives: To review life in twenty century vs. twenty-first century

To help the participants identify and understand "check-out" friendships

To examine the biblical evidence for "check-out" friendships

To assist the participants in forming "check-out" friendships

\section{OPENING REMARKS}

1. Prayer and Welcome

2. Review of Session Two: Four Levels of Friendship Evangelism

A. TWENTY CENTURY LIFE VS. TWENTY-FIRST CENTURY LIFE - WHAT HAPPENED? In culture where we can pull money from a machine and never interact with a bank teller, walk on the crowded sidewalk without meeting another's eyes, and call telephone assistance only to get information from a computerized voice, it's truly possible to be alone in a crowd. National surveys, in fact, find that a quarter of Americans say they're felt lonely in the last month. And if they confess to feeling lonely, two-thirds of Americans say that having close relationships with other people is always on their minds. (Drs. Les \& Leslie Parrott)

1. Life in the twenty century.

a. When life was simpler and commute times were nonexistent, homes were constructed with front porches, so when people took evening walks or afternoon drives, it was commonplace to "run into" neighbors sitting on their porch. One thing usually led to another, and before long, you were invited to sit with them and enjoy casual conversation and a cold beverage. People actually took the time for one another and saw value in this spontaneous interaction. Talk time on the porch was a way of life. (Andy Stanley and Bill Willits)

b. The American front porch further represented the ideal of community in America. For the front porch existed as a zone between the public and private, an area that could be shared between the sanctity of the home and the community outside. It was an area where interaction with the community could take place. (Scott Cook)

2. Life in the twenty-first century. 
a. Today more than three-fourths of the American people live in metropolitan areas, and more than two-thirds of those live in suburbs. (Phillip Langdon)

b. In the midst of busy lives, overcommitted schedules, and congested cities, we feel alone. Although we drive on overcrowded freeways to catch overbooked flights and sit in jam-packed airplanes, we live in isolation. (Andy Stanley and Bill Willits)

c. Retreating from the busyness and intensity of work life, we come home, put the garage door down, and escape. Not outside to the openness of our front porch, but inside to the TV in our living room. And if we go outside, it's not to the porch on the front of our house, it's to the deck on the back of our house. The harsh truth is that after a long, hard day, and perhaps a crowded commute, we don't want to see more people. We want to get away from them! The last thing we want to do at the end of a day is to have one more conversation, be forced to make one more decision, or fulfill one more request. So we shun unplanned interactions by hiding. Our goal is to avoid people-and what they potentially want from us-at all cost! (Andy Stanley and Charles Willits)

3. An interesting fact - You have the option of getting on a plane and visiting 80 percent of the country's population withing two hours! (Andy Stanley and Charles Willits)

4. Having access to people isn't the issue for most of us. So why the loneliness?

a. Even though we live in large cities or communities, work at successful companies, and attend different events, we feel alone. . . Many couples will tell you they experience the same thing. Being married does not exempt someone from the emptiness associated with isolation. We are a culture craving relationship. In the midst of our crowded existence, many of us are living lonely lives. We live and work in a sea of humanity, but we end up missing out on the benefits of regular, meaningful relationships. (Andy Stanley and Charles Willits)

b. We want to be wanted, accepted, enjoyed, and loved. Psychologists call it our "affiliative drive." And make no mistake, no one is too big, strong, talented, or tough to go without belonging. The need to belong is not just about feeling warm and accepted. It's literally, a matter of life or death. (Drs. Les \& Leslie Parrott)

B. JESUS MINGLED WITH PEOPLE AS ONE WHO DESIRED THEIR GOOD. MH 143

1. Mingled with sinners. (Luke 5:29; 15:2) 
2. Ministered to the crowd. (Matt 7:28, 29; 9:35, 36; 13:34-43)

3. Helped out at a wedding. (John 2)

4. Day to day encounters with strangers. (Luke 19)

5. Ministered to the disabled. (John 5)

6. Attended funerals. (Luke 7:11-16)

7. Made time for outsiders. (Luke 7:2-10)

8. Received strangers. (John 1:37-39)

C. HOW TO MAKE CHECK-OUT FRIENDS.

1. Mingle with people.

2. Introduce yourself to them.

3. Be relaxed, be kind, and listen attentively.

4. Ask questions.

5. Value them. (1 Cor 9:22)

D. PRACTICE THE EIGHT RULES OF CONVERSATION

1. Listen attentively.

2. Don't interrupt.

3. Avoid criticizing.

4. Use praise instead of sarcasm.

5. Never talk down to others.

6. Avoid gossip and rumors.

7. Drop pretense; speak to be understood.

8. Treat everybody like somebody.

E. CLASS EXERCISE - PARTICIPANTS ROLE PLAY MAKING ACQUAINTANCES. 
F. THE IMPORTANCE OF CHECK-OUT FRIENDS.

1. The most common of all relationships, but it provides the foundation for all other kinds of relationships.

2. The first sort of relationship which God provides - "Friends along the way."

3. Casual friends enrich and brighten our daily lives - new experiences.

4. People we meet daily with no personal risk involved.

5. We don't choose them, but God does for us usually in public place work, school, church, or community events.

6. Jesus recognized the value of every person He met.

7. People we see simply because of where you live and what you do.

8. Generate the greatest volume of friends with no commitments.

\section{CLOSING}

1. Review main points concerning Check-Out Friends.

2. Preview Session 4 - "How to Make Choice Friends"

3. Homework assignment - Practice making Check-Out Friends.

4. Identify the Check-Out Friends in your life and begin to pray for them daily. 


\section{SESSION FOUR}

"HOW TO MAKE CHOICE FRIENDS"

\section{Objectives: To review "check-out" friendships}

To examine the biblical evidence for "choice" friendships

To help the participants identify and make "choice" friendships

OPENING REMARKS

1. Prayer and welcome

2. Review Session 3: "How to Make Check-Out Friends"

3. Review homework assignment - Practice making Check-Out Friends and pray for them daily

A. JESUS MINGLED AND SHOWED CONCERN FOR OTHERS.

1. He attend social events like weddings. (John 2)

2. He went to homes of people who needed His assistance. (Luke 19:1-10)

3. Christ eat meals with known sinners. (Luke 5:27-32)

4. Went to parties given in His honor. (Matt 26; John 12)

5. Spend time with teaching others (The Seventy), but they were not in His inner circle. (Luke 10:1-22)

6. Jesus did not share with the Seventy His inner secrets. (Luke 10:23, 24)

B. ELLEN WHITE ENCOURAGES BELIEVERS TO BE SOCIAL WITH OTHERS LIKE CHRIST.

1. He reached the hearts of people by going among them an one who desired their good. DA 151

2. He met them at their daily vocations, and manifested an interest in their secular affairs." DA 151

3. Let them see that our religion does not make us unsympathetic or exacting. DA 152

4. We are not to renounce social communion. We should not schedule ourselves from others. In order to reach all classes, we must meet them 
where they are. They will seldom seek us on their own accord ... In the home of the lowly, and in the mansion of the great, at the hospitable bed, and in the gatherings of the innocent social enjoyment. DA 152

\section{HOW TO MAKE IDENTIFY AND MAKE CHOICE FRIENDS.}

1. Based on mutual interests and share common needs and concerns.

2. They come in all shapes and sizes, but not as many.

3. Coworkers who work on projects together and discover common interest.

4. Share a kindred spirit of sorts - "beyond the surface experience" - we connect with them.

5. Built on routine encounters.

6. May be tied to a specific place and time, normally a joyful experience.

7. Share social activities that cross the barrier of age, class, and race.

8. The commitment level of the relationship is based on the social event or activity only, but can be cultivated into a deeper level friendship.

9. We not only know who they are, but what they're about. (Pamela Reeve)

D. BE CAREFUL.

1. Be cautious in friendships. (Prov 12:26)

2. Avoid becoming to close with people who are not walking with Christ.
a. Do not sit in judgment over others.
b. Do not condemn others.
c. Use discernment in what you say and do - do not get involved in corrupt lifestyles.
d. Do not share with them your personal secrets.
e. Be accountable with people of the opposite sex - let your spouse or friend know what is going on at all times.

\section{E. CLASS EXERCISE.}

1. Get in your small group and read Acts 8:26-39. Identify what interest that Philip and the Eunuch had in common.

a. How you do react when you are interrupted by a stranger? 
b. How will you view interruptions in the future?

2. Share with the group the personal activities that you enjoy. Make a list of those activities.

\section{F. CLOSING}

1. Review the main point of the session.

2. Preview Session Five: "How to Make Close Friends"

3. Homework assignment - From your list of social activities that you enjoy, ask a Check-Out Friend to spend time with you in one activity of mutual interest. 


\section{SESSION FIVE}

\section{"HOW TO MAKE CLOSE FRIENDS"}

\section{Objectives: To review both "check-out" and "choice" friendships To examine the biblical evidence for "close" friendships To help the participants identify and learn "how to" make close friends}

\section{OPENING REMARKS}

1. Prayer and welcome

2. Review of Session Four: "How to Make Choice Friends"

A. PEOPLE ARE LOOKING FOR MEANINGFUL RELATIONSHIPS.

1. Everyone wants to be wanted, accepted, enjoyed, and loved... Our need for relationship is all part of God's design. (Drs. Les \& Leslie Parrott)

2. God created us with a hunger for relationship - for relationship with Him and our fellow people. At our very core we are relational beings. The soul cannot prosper without being connected to others. (Dr. Henry Cloud)

3. "So God created man in his own image" (verse 27). Just as God exists in meaningful relationship, so are we to exist in this quality of relationship as well. The need for it is part of our genetic makeup. God is a relational being and $\mathrm{He}$ created His prized creations, you and me, with the need for significant relationship as well. (Andy Stanley and Charles Willits)

B. JESUS MINGLED WITH OTHERS, SHOWED CONCERNED FOR THEM, MET THEIR NEEDS, AND WON THEIR CONFIDENCE.

1. Christ developed His relationship with the Twelve over time.

a. "Come and see." (John 1:37-39)

b. Those who met Him first told the others. (John 1:40-46)

c. Jesus accepts people where they are and as they are. (John 1:50-51)

d. They went to social occasions together. (John 2:1-11)

e. They spent only four months with Him, then they would go home. (Bill Hull)

f. During these four months, He gave them vision of ministry. They saw him perform miracles, clear the temple, witness to both a religious leader and an immoral woman, and challenge the religious establishment. (Bill Hull)

g. The emphasis was on watching Jesus. 
1. He showed them how to study the Word. (Mark 1:21-28)

2. He demonstrated a personal prayer life. (Mark 1:35-38)

3. Modeled friendship evangelism. (Mark 2:15-17)

4. Enjoyed fellowship with them. (John 5:20)

2. Jesus had a special relationship with the Twelve.
a. "Come and follow Me." (Mark 1:16-20; Luke 5:1-11; 6:12-16)
b. They choose to follow Jesus. (Matt 4:18-22; 9:9)
c. Jesus show them how to do it, then do it with them. (Matt 10:8-14; Mark 6:8-13)
d. This was a ten month period of training. (Bill Hull)

3. Jesus would let them do ministry and deploy them to their own ministry. (Bill Hull)
a. "Come and be with Me." (Matt 9:37-38)
c. Jesus gave them instructions before sending them on their first evangelistic meeting. (Matt 10)
b. The requirements were harsh. (Matt 8:18-22 and Matt. 10:16-23)
d. He led by example and shared the work. (Matt 11:1)
e. The Twelve had freedom to speak their minds. (Matt 26:8-9; Matt 16:21-22; Mark 10:35)
f. Christ shared secrets with the Twelve that He did not share with others. (Luke 10:23-24)
g. The twenty month of service with Christ. (Bill Hull)

4. Jesus wanted friends, not servants. (John 15:15)
a. "You will remain in Me." (John 15:7-8)
b. Jesus pours His heart out to them. (John 13-17)
c. He expects to see a change in them. (John 15-17)
d. Christ offers forgiveness when He has been wronged. (John 21)

\section{ELLEN WHITE COMMENTS CONCERNING CHRIST RELATIONSHIP WITH THE TWELVE.}

1. The Savior knew the character of the men whom He had chosen; all their weaknesses and errors were open before Him; He knew the perils through which they must pass, the responsibility that would rest upon them; and His heart yearned over these chosen ones. DA 291, 292

2. Alone upon the mountain near the Sea of Galilee He sent the entire night in prayer for them, while they were sleeping at the foot of the mountain. 
With the first light of dawn He summoned them to meet Him; for He had something of importance to communicate to them. DA 292

3. These disciples had been for some time associated with Jesus in active labor. John and James, Andrew and Peter, with Philip, Nathanael, and Matthew, had been more closely connected with Him than the others, and had witnessed more of His miracles. DA 292

\section{ELLEN WHITE ENCOURAGES BELIEVERS TO BEFRIEND OTHERS.}

1. The strongest argument in favor of the gospel is a loving and lovable Christian. MH 470

2. This simple straightforward, solid reliability in the daily deportment of a Christian will do more to foster and generate fidelity in others than all the preaching of a lifetime. Not only will it encourage our contemporaries to put confidence in us, but much more importantly it will lead them, eventually, to meet the Master and put their trust in Him. MB 134-135

3. These are souls perplexed with doubt, burdened with infirmities, weak in faith, and unable to grasp the Unseen, but a friend whom they can see, coming to them in Christ's stead, can be a connecting link to fasten their trembling faith upon Christ. DA 297

4. Being social and coming close to people, you may turn the current of their thoughts more readily than by the most able discourse. GW 193

5. By personal labor reach those around you. Become acquainted with them. This work cannot be done by proxy. Money lent or given will not accomplish it. By visiting the people, talking, praying, sympathizing with them, you will win hearts.

To do it, you will need resolute, persevering faith, unwearying patience, and a love for souls. $6 \mathrm{~T} 115$

E. HOW TO MAKE CLOSE FRIENDS.

1. Help a person in personal crisis.

2. Need to be in the right place at the right time doing the right thing. (Matt 8:23-27)

3. Share time and experiences.

4. This friendship is established during times of difficulty. (Prov 17:17) 
5. Trust is developed, a bond is formed when this friendship is put to the test. (Prov 27:10)

6. Reach a comfort zone with each other and begin to share more of yourself.

F. CLASS EXERCISE.

1. Get in your group. Read Ruth 1:8-22. Ruth and Naomi's friendship developed through circumstances in their lives-famine, marriage, death, and the need to go in the face of tragedy. How do you think God uses circumstances to develop relationships in our lives?

2. How can even tragedy produce growth in our lives? Briefly share with the group.

\section{G. CLOSING.}

1. Review the main points.

2. Preview Session Six: "How to Introduce People to Your Best Friend"

3. Homework assignment.

a. Contact at least one "close" friend and express gratitude for the friendship.

b. Look for opportunities each day to assist people, especially "checkout" and "choice" friends, in difficulty and be open for a "close" friendship to blossom. 


\section{SESSION SIX}

\section{“HOW TO INTRODUCE PEOPLE TO YOUR BEST FRIEND"}

Objectives: To review the previous forms of friendships

To examine the biblical evidence for "best" friendships

To help the participants identify and understand "how to" have "best" friends

To expose the participants to opportunities to introduce a friend to their "best" friend, Jesus Christ

To have the participants evaluate the seminar

A. JESUS ORGANIZED THE TWELVE INTO SMALLER GROUPS. (WILLIAM YOUNT AND MIKE BARNETT)

1. The first group consisted of Peter, James, John, and Andrew. Peter is always consider the leader of the group. (Note: Andrew introduced Peter to Jesus).

2. The second group consisted of Philip, Bartholomew (Nathanael), Matthew, and Thomas. Philip is listed first among the second group.

3. The third group consisted of James the son of Alphaeus, Thaddeus (Judas the son of James), Simon the Zealot, and Judas Ischariot. James is first among this final group.

4. The scriptural references are found in Matt 10:2-4; Mark 3:16-19; Luke 6:14-16; and Acts 1:13.

B. OF THE TWELVE, JESUS PAID SPECIAL ATTENTION TO PETER, JAMES, AND JOHN. (WILLIAM YOUNT AND MIKE BARNETT)

1. They were present when Jesus healed the daughter of Jairus. The other disciples remained outside. (Mark 5:37-38)

2. These three witnessed the transfiguration of Jesus, Moses, and Elijah on the mountain top while the others remained at the bottom. (Matt 17:1-9)

3. The same three went with Jesus further into the garden of Gethsemane while the other remained at the gate. (Matt 26:36-38)

C. THEIR CHARACTERS WERE TRANSFORMS BECAME OF THEIR RELATIONSHIP WITH JESUS.

1. They overcame their short tempers and large egos - the arrogant fisherman and the "sons of thunder." 
2. The three became leaders in the Christian church.

a. Peter evangelized the Jews.

b. James pastored the church in Jerusalem.

c. John pastored the church in Ephesus.

D. JESUS HAD HIS ONE.

1. John was recognized as "the disciple whom Jesus loved." (John 13:23; 21:20)

2. Jesus entrusted His mother to John's care. (John 19:25-27)

3. John's account of the gospel reveals the personal side of Jesus.

4. The smaller the group, the relationship with Jesus grew deeper.

E. ELLEN WHITE RECOGNIZED THE SMALLER GROUPS AMONG THE TWELVE.

1. These disciples had been for some time associated with Jesus in active labor. John and James, Andrew and Peter, with Philip, Nathanael, and Matthew, had been more closely connected with Him than the others, and had witnessed more of His miracles. DA 292

2. Peter, James, and John stood in still nearer relationship to Him. They were almost constantly with Him, witnessing His miracles, and hearing His words. DA 292

3. John pressed into still closer intimacy with Jesus, so that he is distinguished as the one whom Jesus loved. DA 292

4. John seem to have enjoyed to a pre-eminent degree the friendship of Christ, and he received many tokens of the Saviour's confidence and love. AA 539

5. To his latest days John closely followed the Lord. DA 816

6. His relationship with Christ helped him overcome his proud, self-assertive, ambitious for honor, impetuous, evil temper, revengeful attitude, and spirit of criticism. DA 540

F. IDENTIFYING CHARACTERISTICS OF BEST FRIENDS.

1. Share feelings and emotions, and cares deeply. 
2. Be honest, transparent, and faithful.

3. Offer complete acceptance and provides space.

4. Be willing to confront out of love.

5. Have a given spirit and high commitment.

6. Provide comfort and security at all times.

7. Keep secrets and forgive faults.

8. Celebrate success and laughs easily.

9. Intimate sharing, so you they are few in number usually three or less.

G. CLASS EXERCISE.

1. Get into your group and read 1Sam 13-14; 18:1-4; 19:1-6; and 20:1-42.

2. What characteristics of a "best" friend do you find? List.

3. How did Jonathan respect his father, the king, and not compromise his friendship with David?

H. SIX WAYS TO DEVELOP AN INTIMATE FRIENDSHIP. (JOHN 14:1-18)

1. An intimate friend is an encouraging friend. (verses 1-4)

2. Honesty begins to surface. You can ask real questions. (verses 2, 5)

3. There are times of confrontation. (verses 8-12)

a. This is the most difficult point in developing a relationship with a friend.

b. Ask yourself three questions before confronting a person:

1. Am I confronting for their benefit or mine?

2. Do I have the right attitude?

3. If they react wrongly will I act correctly?

4. A giving spirit is displayed. (verses 13,14 )

5. Proven love develops. (verse 15)

6. Comfort and security is generated. (verses 16-18) 
I. JESUS MODELS HOW TO LEAD A FRIEND TO CHRIST. (JOHN 4)

1. Jesus did not allow his personal or physical feelings to effect his witnessing. Effective friendship evangelism is as much character as it is burden. (vs. 6)

2. Jesus' conversation began on her level of understanding. (vs. 7)

a. "Give me something to drink."

b. He met her on common ground.

3. Jesus conversation began on her level of understanding. (vs. 7)

a. Do not be a know-it-all.

b. Have a "can you help me" attitude.

4. Jesus saw her soul and not her skin. (vs. 9)

a. Jesus knew no barriers. He crossed all barriers.

b. He talked to a Samaritan, a woman, and not a good moral woman.

5. Jesus turned her thoughts to spiritual conversation. (vs. 10)

a. This is the most difficult part.

b. Go to spiritual things in a positive way.

c. Take their negative problem and turn it into a positive.

d. They will listen to your answer if you're living it.

6. Jesus continued to share even though she did not understand everything. (verses 11-14)

7. Jesus wetted her appetite for spiritual things. (vs. 14)

8. Jesus received wisdom that enabled Him to touch her life. (verses 15-19)

a. He went right to where her problem was.

b. He that winneth souls is wise. (Prov 11:30)

c. He that lacks wisdom let him ask of God. Jas 1:5

9. Jesus was not side-tracked when the subject was changed. (verses 19-24)

a. "You're a Seventh-day Adventist, I'm a Baptist."

b. Remember Jesus saves.

c. Smile, agreed, and get back to the subject.

10. Jesus told her His great secret - "I'm your answer." (verses 25-26) 
11. Jesus waited until her heart was prepared. (vs. 26)

12. Jesus rejoiced over the conversion of His friend, and it meet His needs. (verses 32-34)

13. Jesus increased His vision for many because He shared with one. (verses 35-38)

14. Jesus touched the lives of many because He touched the life of one. (verses $39-42)$

\section{J. CLOSING}

1. Review the main points.

2. Evaluation form is filled out.

3. Final remarks of thanks.

4. Issued certificates.

5. Homework assignment:

a. Continue to practice the concepts shared about friendships.

b. Invite and bring a friend to church the following Sabbath. 
APPENDIX H

CLIMBING FRIENDSHIP MOUNTAIN

SEMINAR EVALUATIONS 
A. Demographics

1. Age Range: $18-35$ 36-50

$51-65$

$65+$

2. Gender: $M$

F

3. Church Member

Visitor

B. Presentation

1. Did the presentation seem prepared?

2. Material was covered: Too slow Good Pace Too Fast

3. To what extend did the instructor have a motivating effect, contributing to your learning?

5

To a very great extent
4

3

To some extent
1

To little or no extent

4. To what extent did the instructor's interaction with the participants facilitate your learning?

5

To a very great extent
4

3

To some

extent
2

1

To little

or no extent

C. Program

5. How much did you learn? A lot

A Little

Nothing

6. Would you recommend that others attend this program?

5

Yes Definitely
4

3

Possibly
2

1 Definitely not 
7. What did you find most useful about the program?

8. What, if anything should have been included that was not? Please write any additional comments you might have. Thank you. 
Climbing Friendship Mountain Seminar Evaluation (Pastor/Leader)

\section{A. Presentation}

1. Could your participants follow the presenter well?

2. Was the presenter's points clear and concise?

\section{B. Program}

1. Were there any non-members in attendance?

2. Was the program geared to the needs of your participants?

3. To what extent did the program meet your expectations in terms of value and quality?

4. How relevant was the program to your church and its ministries?

5. Would you recommend the program to other pastors/churches?

6. Additional Comments:

C. Demographics

1. Exact Attendance

Number of Visitors

2. Church Name \& Address 
BIBLIOGRAPHY 


\section{BIBLIOGRAPHY}

Abraham, William J. "A Theology of Evangelism: The Heart of the Matter." Interpretation 48 (1997): 117.

Adams, James R. So You Can't Stand Evangelism? Cambridge, MA: Cowley, 1994.

Adams, Jay E. Shepherding God's Flock. Grand Rapids, MI: Zondervan, 1975.

Ahn, Che. Fire Evangelism. Grand Rapids, MI: Chosen, 2006.

Aldrich, Joseph C. Gentle Persuasion. Portland, OR: Multnomah, 1988. . Lifestyle Evangelism. Sisters, OR: Questar, 1993.

Anderson, Leith. Becoming Friends with God. Minneapolis: Bethany, 2001.

Anderson, Lynn. They Smell Like Sheep. West Monroe, LA: Howard, 1997.

Anderson, Mac. Companies Don't Succeed... People Do! Aurora, IL: Successories, 1998.

Anderson, Neil T., and Elmer L. Towns. Rivers of Revival. Ventura, CA: Regal, 1997.

Anderson, Ray S. The Soul of Ministry. Louisville, KY: Westminister, 1997.

Anderson, Robert C. The Effective Pastor: A Practical Guide to the Ministry. Chicago: Moody, 1985.

Arias, Morthimer, and Alan Johnson. The Great Commission. Nashville: Abingdon, 1992.

Armstrong, D. Wade. Evangelistic Growth in Acts 1 and 2. Nashville: Broadman, 1983.

Armstrong, Richard Stoll. The Pastor as Evangelist. Philadelphia: Westminister, 1984.

Arn, Win. The Church Growth Ratio Book. Pasadena, CA: Church Growth, 1987.

Arn, Win, and Charles Win. The Master's Plan for Making Disciples. Grand Rapids, MI: Baker, 1998. 
Arthur, Kay. As Silver Refined. Colorado Springs, CO: Waterbrook, . Our Covenant God. Colorado Springs, CO: Waterbrook, 1999.

Ash, Mary Kay. Mary Kay on People Management. New York: Warner, 1984.

Bader-Saye, Scott. Following Jesus in a Culture of Fear. Grand Rapids, MI: Brazos, 2007.

Baggett, Byrd. Dare to Soar. Aurora, IL: Successories, 1996.

Bailey, Keith M. Servants in Charge. Camp Hill, PA: Christian, 1979.

Baldwin, Carol Lesser. Friendship Counseling. Grand Rapids, MI: Zondervan, 1988.

Barna, George. Generation Next: What You Need to Know About Today's Youth. Ventura, CA: Regal, 1995.

. Grow Your Church from the Outside. Ventura, CA: Regal, 2002.

. Growing True Disciples. Colorado Springs, CO: Waterbrook, 2001.

. Revolution. Wheaton, IL: Tyndale, 2005.

. Single Focus. Ventura, CA: Regal, 2003.

Barna, George, and Harry R. Jackson, Jr. High Impact African-American Churches. Ventura, CA: Regal, 2004.

Barr, Jerram. The Heart of Evangelism. Wheaton, IL: Crossway, 2001.

Barton, Ruth Haley. Equal to the Task. Downers Grove, IL: InterVarsity, 1998.

Bechtle, Mike. Evangelism for the Rest of Us. Grand Rapids, MI: Baker, 2006.

Beckworth, Bill. Serving God's Purpose in Our Generation. Decatur, GA: Isaiah 55, 1999.

Beougher, Timothy, and Alvin Reid. Evangelism for a Changing World. Wheaton, IL: Harold Shaw, 1995.

Bickel, Bruce, and Stan Jantz. I'm Fine with God . . It's Christians I Can't Stand. Eugene, OR: Harvest, 2008.

Blackaby, Henry T. Created to be God's Friend. Nashville: Thomas Nelson, 1999. 
Blackaby, Henry, and Richard Blackaby. The Experience. Nashville: Broadman and Holman, 1999.

. Spiritual Leadership. Nashville: Broadman and Holman, 2001.

Blanchard, Ken, John P. Carlos, and Alan Randolph. The Three Keys to Empowerment. San Francisco: Berrett-Koehler, 1999.

Bland, Michael, Alison Theaker, and David Wragg. Effective Media Relations. London: Kogan Page, 2000.

Blank, Warren. The 108 Skills of Natural Born Leaders. New York: AMACOM, 2001.

Bloede, Louis W. The Effective Pastor. Minneapolis: Fortress, 1996.

Boa, Kenneth. That I May Know God. Sisters, OR: Multnomah, 1998.

Bolton, Robert, and Dorothy Grover Bolton. People Styles at Work. New York: AMACOM, 1996.

Booker, Richard. The Miracle of the Scarlet Thread. Shippensburg, PA: Destiny Images, 1981.

Bonhoeffer, Dietrich. The Cost of Discipleship. New York: Macmillan, 1963.

Borthwick, Paul. Stop Witnessing and Start Loving. Colorado Springs, CO: Navpress, 2003.

Bozeman, Jeanine Cannon, and Argile Smith. Interpersonal Relationship Skills for Ministers. Gretna, LA: Pelican, 2004.

Brestin, Dee. The Friendships of Women. Colorado Springs, CO: Cook Communications, 1997.

Bright, Bill. Witnessing without Fear. Nashville: Thomas Nelson, 1993.

Broker, Rodney Lee. "Friendship Evangelism." D.Min. dissertation, Christ Seminary, Seminex, 1982.

Brown, Truman, and James E. Hightower. After They Join. Nashville: Convention, 1994.

Brueggemann, Walter. Biblical Perspectives on Evangelism. Nashville: Abingdon, 1993.

Brunson, Mac, and Ergun Caner. Why Churches Die. Nashville: Broadman and Holman, 2005. 
Bryan, Dawson C. A Workable Plan of Evangelism. Nashville: Abingdon, 1945.

Bryant, Eric Michael. Peppermint-Filled Pinatas. Grand Rapids, MI: Zondervan, 2007.

Burke, John. No Perfect People Allowed. Grand Rapids, MI: Baker, 2005.

Burrill, Russell. The Life and Mission of the Local Church. Fallbrook, CA: Hart Research Center, 1998.

. Radical Disciples for Revolutionary Churches. Fallbrook, CA: Hart Research Center, 1996.

. Revolution in the Church. Fallbrook, CA: Hart Research Center, 1993.

. The Revolutioned Church of the $21^{\text {st }}$ Century. Fallbrook, CA: Hart Research Center, 1997.

Buzzard, Lynn R., and Laurence Eck. Tell It to the Church. Elgin, IL: Cook, 1982.

Cameron, Kirk, and Ray Comfort. The Way of the Master Basic Training Course. Bartlesville, OK: Genesis, 2002.

Campolo, Tony. Following Jesus without Embarrassing God. Dallas: Word, 1997.

Carneige, Dale. How to Stop Worrying and Start Living. New York: Galahad, 1998. . How to Win Friends and Influence People. New York: Galahad, 1998.

Carter, Les, and Jim Underwood. The Significance Principle. Nashville: Broadman and Holman, 1998.

Case, Steve. Shall We Dance. Riverside, CA: La Sierra University Press, 1996.

Cherry, Reginald. Healing Prayer. Nashville: Thomas Nelson, 1999.

Christensen, Michael J. Equipping the Saints. Nashville: Abingdon, 2000.

Cladis, George. Leading the Team-Based Church. San Francisco: Jossey-Bass, 1999.

Clark, Jeramy, and Jerusha Clark. Define the Relationship. Colorado Springs, CO: Water Brook, 2004.

Clinton, Tim, Archibald Hart, and George Ohlschlager. Caring for People God's Way. Nashville: Thomas Nelson, 2005. 
Cloud, Henry, and John Townsend. Boundaries in Dating. Grand Rapids, MI: Zondervan, 2000.

. How to Have That Difficult Conversation You're Been Avoiding. Grand Rapids, MI: Zondervan, 2005.

Clowers, Don. Right and Wrong Expectations in Friendship. Tulsa, OK: Harrison, 2000.

Cocoris, Michael. Evangelism: A Biblical Approach. Chicago: Moody, 1984.

Coffman, Carl. The Thrill of Living Within God's Will. Berrien Springs, MI: by the author, 1985.

. Unto a Perfect Man. Berrien Springs, MI: Andrews University Press, 1969.

Cohen, William A. Wisdom of the Generals. Paramus, NJ: Prentice Hall, 2001.

Coleman, Robert E. The Master's Way of Personal Evangelism. Wheaton, IL: Crossway, 1997.

Comfort, Ray. The Way of the Master. Orlando, FL: Bridge-Logos, 2006.

Conn, Harvie M. Evangelism: Doing Justice and Preaching Grace. Grand Rapids, MI: Zondervan, 1982.

Coon, Glen A. Path to the Heart. Hagerstown, MD: Review and Herald, 1986.

Cooper, Douglas. Living God's Love. Mountain View, CA: Pacific Press, 1975.

Cope; Mike, and Rubel Shelly. What Would Jesus Do Today? West Monroe, LA: Howard, 1998.

Cordeiro, Wayne. Doing Church as a Team. Ventura, CA: Regal, 2001.

Couden, Barbara. Understanding Intimate Violence. Hagerstown, MD: Review and Herald, 1999.

Covey, Stephen R. How to Succeed with People. Salt Lake City, UT: Desert, 1971. . The Seven Habits of Highly Effective People. New York: Fireside, 1989.

Crabb, Lawrence J. Connecting. Nashville: Word, 1997.

. Inside Out. Colorado Springs, CO: Navpress, 2007.

. Understanding People. Grand Rapids, MI: Zondervan, 1987. 
Crabb, Lawrence J., and Dan Allender. Encouragement. Grand Rapids, MI: Zondervan, 1984.

Craigie, P. C. The Book of Deuteronomy. Grand Rapids, MI: Eerdmans, 1976.

Crawford, Dan R. EvangeLife: A Guide to Life-style Evangelism. Nashville: Broadman, 1984.

Cress, James A. Common Sense Ministry. Silver Spring, MD: Ministerial Association of General Conference of Seventh-day Adventists, 1999.

Daniels, Aubrey C. Bringing Out the Best in People. Washington, DC: McGraw-Hill, 2000.

. Other People's Habits. Washington, DC: McGraw-Hill, 2001.

Dawson, Scott. The Complete Evangelism Guidebook. Grand Rapids, MI: Baker, 2006.

Dennison, Jack. City Reaching. Pasadena, CA: William Carey Library, 1999.

Detamore, Fordyce W. Seeking His Lost Sheep. Hagerstown, MD: Review and Herald, 1980.

DeVille, Jard. The Psychology of Witnessing. Silver Springs, MD: Ministerial Association of General Conference of Seventh-day Adventists, 1996.

Dixon, Paull. Door to the Cities. Washington, DC: Temperance Department of General Conference of Seventh-day Adventists, 1975.

Dobbins, Gaines S. Building Better Churches. Nashville: Broadman, 1947.

Donovan, Daryl G. Men Mentoring Men: A Men's Discipleship Course. Lima, OH: CSS, 1998.

Dossman, Craig A. From House to House. Lincoln, NE: Baby Boomer Ministries Resource Center, 1994.

Dotterweich, Kass P., and John D. Perry. Friendship Therapy. St. Meinrad, IN: One Caring Place Abbey, 1994.

Douglas, J. D. Let the Earth Hear His Voice. Minneapolis: World Wide, 1975.

Dreisbach, Bruce Roberts. The Jesus Plan. Colorado Springs, CO: Water Brook, 2002.

Dudley, Roger L. Why Our Teenagers Leave the Church. Hagerstown, MD: Review and Herald, 2000. 
Dybdahl, Jon L. Adventist Mission in the $21^{\text {st }}$ Century. Hagerstown, MD: Review and Herald, 1999.

Dyer, Charles. The Power of Personal Integrity. Wheaton, IL: Tyndale, 1997.

Easum, Bill. Leadership on the Otherside. Nashville: Abingdon, 2000. . Put on Your Own Oxygen Mask First. Nashville: Abingdon, 2004.

Easum, Bill, and Bil Cornelius. Go Big. Nashville: Abingdon, 2006.

Easum, Bill, and Dave Travis. Beyond the Box. Loveland, CO: Group, 2003.

Edwards, Rex D. Every Believer a Minister. Silver Springs, MD: Ministerial Association of General Conference of Seventh-day Adventists, 1995.

Eims, Leroy. One to One Evangelism. Wheaton, IL: Victor, 1990.

Eisenman, Tom. Everyday Evangelism. Downers Grove, IL: InterVarsity, 1987.

Elliott, Lynda D. How Can I Help? Grand Rapids, MI: Chosen, 2003.

Elmer, Duane. Cross-Cultural Servanthood. Downers Grove, IL: InterVarsity, 2006.

Essex, Louellen, and Mitchell Kusy. Fast Forward Leadership. London: Prentice Hall, 1999.

Etuk, Emma Samuel. Friends: What Would I Do Without Them? Washington, DC: Emida International, 1999.

Exley, Richard. Blue Collar Christianity. Tulsa, OK: Honor, 1989.

Fagerstrom, Douglas L. The Ministry Staff Member. Grand Rapids, MI: Zondervan, 2006.

Faley, Roland J. Bonding with God. New York: Paulist, 1997.

Farmer, David A. Power Witnessing. Hagerstown, MD: Review and Herald, 1999.

Fehr, Beverly. Friendship Processes. Thousand Oaks, CA: Sage, 1996.

Feucht, Oscar E. Everyone a Minister. St. Louis: Concordia, 1974.

Finley, Mark. Decisions. Silver Spring, MD: Ministerial Association of General Conference of Seventh-day Adventists, 1984. . Padded Pews or Open Doors. Boise, ID: Pacific Press, 1988. 
Fisher, Roger, and Scott Brown. Getting Together. New York: Penguin, 1988.

Fletcher, Kingsley. The Power of Covenant. Ventura, CA: Regal, 2000.

Fletcher, Michael. Overcoming Barriers to Growth. Minneapolis: Bethany, 2006.

Ford, Leighton. Transforming Leadership. Downers Grove, IL: InterVarsity, 1991.

Franck, Dennis. Reaching Single Adults. Grand Rapids, MI: Baker, 2007.

Frye, John W. Jesus the Pastor. Grand Rapids, MI: Zondervan, 2000.

Fryer, Kelly A. A Story Worth Sharing. Minneapolis: Augsburg Fortress, 2004.

Gaither, Gloria, Peggy Benson, Sue Buhanan, and Joy MacKenzie. Friends Through Thick and Thin. Grand Rapids, MI: Zondervan, 1998.

Galloway, Dale E. The Fine Art of Getting Along with Others. Portland, OR: Scott, 1984. . On-Purpose Leadership. Kansas City, MO: Beacon Hill, 2001.

Gangel, Kenn. Coaching Ministry Teams. Nashville: Word, 2000.

Gangel, Kenneth O. Team Leadership in Christian Ministry. Chicago: Moody, 1997.

"Genesis." Seventh-Day Adventist Bible Commentary. Edited by F. D. Nichol. Hagerstown, MD: Review and Herald, 2002. 1:251.

George, Carl E., and Robert E. Logan. Leading and Managing Your Church. Old Tappan, NJ: Fleming H. Revell, 1987.

Getz, Gene A. The Measure of a Healthy Church. Chicago: Moody, 2007.

Gibbs, Gary. Winsome Witnessing. Modesto, CA: Nike, 2003.

Gilbert, Larry. Team Evangelism. Lynchburg, VA: Church Growth Institute, 1992.

Gilles, Jerry. Friends-The Power and Potential of the Company You Keep. New York: Coward, McCann, and Geoghegan, 1976.

Girard, Joe. How to Sell Yourself. New York: Warner, 1979.

Gladden, Ron. The 7 Habits of Highly Ineffective Churches. Lincoln, NE: Advent Source, 2003. 
. Plant the Future: So Many Churches! Why Plant More? Nampa, ID: Pacific Press, 2000.

Glaser, Judith E. Creating We. Avon, MA: Platinum Press, 2005.

Gorton, Dennis L. Leading the Followers by Following the Leader. Camp Hill, PA: Christian, 2000.

Green, Michael. Evangelism Now and Then. Downers Grove, IL: InterVarsity, 1979.

Gruits, Patricia Beall. Understanding God and His Covenants. Rochester, MI: PeterPat, 1985.

Habenicht, Donna J. Ten Values Every Kid Should Know. Hagerstown, MD: Review and Herald, 2000.

Haggard, Ted. Dog Training, Fly Fishing, \& Sharing Christ in the $21^{\text {st }}$ Century. Nashville: Thomas Nelson, 2002.

Halcomb, James, David Hamilton, and Howard Malmstadt. Courageous Leaders: Transforming Their World. Seattle: YWAM, 2000.

Hamlin, Sonya. How to Talk so People Listen. New York: Harper and Row, 1998.

Hamm, Richard L. Recreating the Church. St. Louis: Chalice, 2007.

Hammond, Mac. Positioned for Promotion. Tulsa, OK: Harrison, 2000.

Hanchey, Howard. From Survival to Celebration. Boston: Crowley, 1994.

Hansen, David. The Power of Loving Your Church. Minneapolis: Bethany, 1998.

Harbaugh, Gary L., Rebecca Lee Brenneis, and Rodney R. Hutton. Covenants and Care. Minneapolis: Fortress, 1998.

Harley, Willard F. The One. Grand Rapids, MI: Revell, $2002^{\circ}$.

Harris, Joshua. I Kissed Dating Goodbye. Sisters, OR: Multnomah, 1997.

Hasel, Gerhard F. Covenant in Blood. Mountain View, CA: Pacific Press, 1982.

Haskell, Stephen N. The Cross and Its Shadow. Nashville: Southern, 1970.

Hawkins, Don. Master Discipleship. Grand Rapids, MI: Kregel, 1996.

Hayden, Keavin. Lifestyles of the Remnant. Hagerstown, MD: Review and Herald, 2001. 
Haynes, Carlyle B. Living Evangelism. Takoma Park, MD: Review and Herald, 1937.

Heisler, Robert L. "A Program for Caring Church Ministry in the Eugene, Oregon, Seventh-day Adventist Church.” D.Min. dissertation, Andrews University, 1987.

Henderson, James K. Evangelism Without Additives. Colorado Springs, CO: Waterbrook, 2007.

Hendricks, Howard G. Color Outside the Lines. Nashville: Word, 1998.

Heppenstall, Edward. Our Firm Foundation. 2 vols. Washington, DC: Review and Herald, 1952.

Herrington, Jim, Mike Bonem, and James H. Furr. Leading Congregational Change. San Francisco: Jossey-Bass, 2000.

Hesselbein, Frances, and Paul M. Cohen. Leader to Leader. San Francisco: Jossey-Bass, 1999.

Hewitt, Hugh. The Embarrassed Believer. Nashville: Word, 1998.

Hill, Bryon K. Secrets to Better Relationships. Douglasville, PA: Treasures of Heaven, 1991.

Hinson, E. Glenn. Spiritual Preparation for Christian Leadership. Nashville: Upper Room, 1999.

Horst, Tamyra. The Gift of Friendship. Nampa, ID: Pacific Press, 1999.

Howe, Leroy. A Pastor in Every Pew. Valley Forge, PA: Judson, 2000.

Howell, R. B. C. The Cross and the Covenants. Harrisonburg, VA: Sprinkle, 1994.

Hoyt, William R. Effectiveness by the Numbers. Nashville: Abingdon, 2007.

Huggins, Kevin D. Friendship Counseling. Colorado Springs, CO: Navpress, 2003.

Hughes, R. Kent. Disciplines of a Godly Man. Wheaton, IL: Crossway, 1991.

Hughes, Selwyn. The Introvert's Guide to Spontaneous Witnessing. Minneapolis: Bethany, 1983.

Hull, Bill. The Complete Book of Discipleship. Colorado Springs, CO: Navpress, 2006.

Hunter, George G. How to Reach Secular People. Nashville: Abingdon, 1992. 
Huskins, David. The Power of the Covenant Heart. Shippensburg, PA: Destiny Image, 2000.

Hybels, Bill. Just Walk Across the Room. Grand Rapids, MI: Zondervan, 2006. . Making Life Work. Downers Grove, IL: InterVarsity, 1998.

Hybels, Bill, and Mark Mittelberg. Becoming a Contagious Christian. Grand Rapids, MI: Zondervan, 1994.

Innes, Dick. I Hate Witnessing. Ventura, CA: Regal, 1983.

Intrater, Keith. Covenant Relationships. Shippensburg, PA: Destiny Images, 1989.

Jacobsen, Wayne, and Clay Jacobsen. Athentic Relationships. Grand Rapids, MI: Baker, 2003.

Jeffress, Robert. When Forgiveness Doesn't Make Sense. Colorado Springs, CO: Waterbrook, 2000.

Johnson, Kim A. Spiritual Body Building Manual. Silver Spring, MD: Ministerial Association of General Conference of Seventh-day Adventists, 1997.

Johnson, Kurt. Small Group Outreach. Hagerstown, MD: Review and Herald, 1991. 1997.

Jones, Laurie Beth. Jesus, Inc. New York: Crown Business, 2001.

Jones, Mark S. Reclaiming Inactive Church Members. Nashville: Broadman, 1988.

Jones, Peter. Capturing the Pagan Mind. Nashville: Broadman and Holman, 2003.

Jones, Timothy. The Friendship Connection. Wheaton, IL: Tyndale, 1993.

June, Lee N., and Matthew Parker. Evangelism and Discipleship in African-American Churches. Grand Rapids, MI: Zondervan, 1999.

Kaufman, Pat, and Cindy Wetmore. The Brass Tacks Manager. New York: Doubleday, 1994.

Keefauver, Larry. Friends and Faith: Friendship Evangelism in Youth Ministry. Loveland, CO: Group Books, 1986.

Keller, Timothy. Ministries of Mercy. Grand Rapids, MI: Zondervan, 1989. 
Kelley, Chuck. Learning to Share My Faith. Nashville: LifeWay, 1994.

Kennedy, D. James. Evangelism Explosion. Wheaton, IL: Tyndale, 1996.

Kenyon, E. W. The Blood Covenant. Lynnwood, WA: Kenyon's Gospel Publishing, Society, 1969.

Kibbey, Sue Nilson. Ultimately Responsible. Nashville: Abingdon, 2006.

Kidner, Derek. Genesis. Downers Grove, IL: InterVarsity, 1967.

Kinlaw, Dennis C. Coaching for Commitment. San Francisco: Jossey-Bass, 1999.

Kinnaman, David, and Gabe Lyons. Unchrisitian. Grand Rapids, MI: Baker, 2007.

Kinnaman, Gary, and Alfred H. Ells. Leaders That Last. Grand Rapids, MI: Baker, 2003.

Kis, Miroslav M. Follow Me. Hagerstown, MD: Review and Herald, 2001.

Kleuser, Louise C. The Bible Instructor. Brushton, NY: Teach, 1993.

Klopp, Henry. The Ministry Playbook. Grand Rapids, MI: Baker, 2002.

Koessler, John. True Discipleship. Chicago: Moody, 2003.

Kouzes, James M., and Barry Z. Posner. Encouraging the Heart. San Franciso: JosseyBass, 1999.

Kraemer, Hendrik. A Theology of the Laity. Philadelphia: Westiminster, 1958.

Kramp, John. Out of Their Faces and into Their Shoes. Nashville: Broadman and Holman, 1995.

Kubo, Sakae. The God of Relationships. Hagerstown, MD: Review and Herald, 1993.

Ladd, Karol, and Terry Ann Kelly. The Power of a Positive Friend. West Monroe, LA: Howard, 2004.

Lampman, Lisa Barnes. Helping a Neighbor in Crisis. Wheaton, IL: Tyndale, 1997.

Lane, Tim, and Paul Tripp. Relationships: A Mess Worth Making. Greensboro, NC: New Growth, 2006.

Larimore, Walter L. 10 Essentials of Highly Healthy People. Grand Rapids, MI: Zondervan, 2003. 
Leuthauser, Karl, ed. Friendship First. Loveland, CO: Group, 2005.

Lee, Witness. Abraham Called by God. Anaheim, CA: Living Stream Ministry, 1998.

Leeds, Dorothy. Power Speak. New York, Berkley, 1988.

. The Seven Powers of Questions. New York: Berkley, 2000.

Lewis, Phillip V. Transforming Leadership. Nashville: Broadman and Holman, 1996.

Lewis, Robert. The Church of Irresistible Influence. Grand Rapids, MI: Zondervan, 2001.

Lindgren, Alvin J., and Norman Shawchuck. Let My People Go. Nashville: Abingdon, 1980.

Little, Paul E. How to Give Away Your Faith. Chicago: InterVarsity, 1966.

Lohfink, Norbert. The Covenant Never Revoked. New York: Paulist, 1991.

Lombardi, Vince, Jr. What It Takes to be \#1: Vince Lombardi on Leadership. New York: McGraw-Hill, 2001.

Losoncy, Lewis E. Best Team Skills. Delray Beach, FL: St. Lucie, 1997.

Lundy, Jim. Lead, Follow, or Get Out of the Way. New York: Berkley, 1986.

MacArthur, John. Rediscovering Pastoral Ministry. Dallas: Word, 1995.

MacCarty, Skip. In Granite or Ingrained? Berrien Springs, MI: Andrews University Press, 2007.

Macchia, Stephen A. Becoming a Healthy Church. Grand Rapids, MI: Baker, 2003. . Becoming a Healthy Disciple. Grand Rapids, MI: Baker, 2004.

MacDonald, Gordon. Who Stole My Church? Nashville: Thomas Nelson, 2007.

Mackoff, Barbara, and Gary Wenet. The Inner Work of Leaders. New York: AMACOM, 2001.

MacMillian, Pat. The Performance Factor. Nashville: Broadman and Holman, 2001.

Malphurs, Aubrey. Advanced Strategic Planning. Grand Rapids, MI: Baker, 2005. Maximizing Your Effectiveness. Grand Rapids, MI: Baker, 2006. 
. Ministry Nuts and Bolts. Grand Rapids, MI: Kregel, 1997.

. A New Kind of Church. Grand Rapids, MI: Baker, 2007.

Pouring New Wine into Old Wineskins. Grand Rapids, MI: Baker, 1993.

. Values-Driven Leadership. Grand Rapids, MI: Baker, 2004.

Marple, Joy. Your Friendship is Heaven Sent. Grand Rapids, MI: Zondervan, 1977.

Martin, Carlos G. Turning the World Upside Down. Nampa, ID: Pacific Press, 2000.

Maxwell, Graham. Servants or Friends? Redlands, CA: Pineknoll, 1992.

Maxwell, John. Be a People Person. Wheaton, IL: Victor, 1988.

. Be All You Can Be! Wheaton, IL: Victor, 1989.

. The Power of Partnership in the Church. Nashville: J. Countryman, 1999.

. Think on These Things. Kansas City, MO: Beacon Hill, 1979.

The Treasure of a Friend. Nashville: J. Countryman, 1999.

Maynard-Reid, Pedrito U. Complete Evangelism: The Luke-Acts Model. Scottdale, PA: Herald, 1997.

Mays, Carl. Anatomy of a Leader. Aurora, IL: Successories, 1997.

McCutcheon, Michael. Rebuilding God's People. Camp Hill, PA: Christian, 1993.

McDonald, Glenn. The Disciple Making Church. Grand Haven, MI: Faith Walk, 2007.

McDill, Wayne. Making Friends for Christ. Nashville: Broadman, 1979.

McGinnis, Alan Loy. Bringing Out the Best in People. Minneapolis: Augsburg, 1985. . The Friendship Factor. Minneapolis: Augsburg, 1979.

McIntosh, Gary L. Beyond the First Visit. Grand Rapids, MI: Baker, 2006. . Church That Works. Grand Rapids, MI: Baker, 2004.

. One Church Four Generations. Grand Rapids, Baker, 2002.

. One Size Doesn't Fit All. Grand Rapids, MI: Baker, 2002. 
McIntosh, Gary L., and R. Daniel Reeves. Thriving Churches in the Twenty-First Century. Grand Rapids, MI: Baker, 2006.

McKay, William J. Me, an Evangelist? Every Christian's Guide to Caring Evangelism. St. Louis, MO: Stephen Ministries, 1992.

McLaren, Brian D. A New Kind of Christian. San Francisco: Jossey-Bass, 2001.

McLemore, Clinton W. Toxic Relationships and How to Change Them. San Francisco: Jossey-Bass, 2003.

McQuilkin, Robertson. The Five Smooth Stones. Nashville: Broadman and Holman, 2007.

McRaney, William. The Art of Personal Evangelism. Nashville: Broadman and Holman, 2003.

McSwain, Larry L., and William C. Treadwell, Jr. Conflict Ministry in the Church. Silver Spring, MD: Ministerial Association of General Conference of Seventh-day Adventists, 1997.

Meyer, Joyce. A Leader in the Making. Tulsa, OK: Harrison, 2001.

Miles, Delos. Master Principles of Evangelism. Nashville: Broadman, 1982.

Miller, J. R. Closer Than a Brother. Chicago: Moody, 1995.

Mittelberg, Mark. Building a Contagious Church. Grand Rapids, MI: Zondervan, 2000.

Moore, R. York. Giving Your Faith by Giving It Away. Downers Grove, IL: InterVarsity, 2005.

Moore, Ralph. Friends: The Key to Reaching Generation X. Ventura, CA: Regal, 2001.

Mosley, Steven. Secrets of Jesus Touch. Colorado Springs, CO: Navpress, 2003.

Munson, Lloyd I. "Formation and Development of Caring Ministries Based on Neighboring Evangelism Model." D.Min. dissertation, Andrews University, 1989.

Murray, Andrew. Covenants and Blessings. Springdale, PA: Whitaker, 1984. . In Search of Spiritual Excellence. Springdale, PA: Whitaker, 1984.

Neal, Connie. Holding on to Heaven: While Your Friend Goes Through Hell. Nashville: Word, 1999. 
Nee, Watchman. The Better Covenant. New York: Christian Fellowship, 1982.

Neuenschwander, Mark, and Betsy Neuenschwander. Crisis Evangelism. Ventura, CA: Regal, 1999.

Norman, Ernan A. A Strategy for Reaching Secular People. Bloomington, IN: Author House, 2007.

North American Mission Board. The NET Evangelism for the $21^{\text {st }}$ Century. Alpharetta, GA: NAMB, 2000.

Noyce, Gaylord. The Art of Pastoral Conversation. Atlanta: John Knox, 1981.

O'Ffill, Daniel W., and Carrol Johnson Shewmake. What to Say. Hagerstown, MD: Review and Herald, 1994.

O'Ffill, Richard W. Expect Great Things. Hagerstown, MD: Review and Herald, 2001.

Ogden, Greg. Transforming Discipleship. Downers Grove, IL: InterVarsity, 2003. . Unfinished Business. Grand Rapids, MI: Zondervan, 20003.

Olford, Stephen. The Secrets of Soul Winning. Nashville: Broadman and Holman, 2007.

Olson, David T. The American Church in Crisis. Grand Rapids, MI: Zondervan, 2008.

Ortberg, John. Everybody's Normal Till You Get to Know Them. Grand Rapids, MI: Zondervan, 2003.

. When the Game is Over It All Goes Back in the Box. Grand Rapids, MI: Zondervan, 2007.

Ott, E. Stanley. Transform Your Church with Ministry Teams. Grand Rapids, MI: Eerdmans, 2004.

Packer, James I. Evangelism and the Sovereignty of God. Chicago: InterVarsity, 1961.

Parker, Glenn. Teamwork. Aurora, IL: Successories, 1998.

Parrott, Les. The Control Freak. Wheaton, IL: Tyndale, 2000.

Parrott, Les, and Leslie Parrott. Relationships. Grand Rapids, MI: Zondervan, 1998. . Ten Traits for Enduring Ties: A Good Friend. Ann Arbor, MI: Vine, 1998. 
Patterson, Kerry, Joseph Grenny, Ron McMillan, and Al Switzler. Crucial Conversations. New York: McGraw Hill, 2002.

Paulien, Jon. Knowing God in the Real World. Nampa, ID: Pacific Press, 2000.

. Meet God Again for the First Time. Hagerstown, MD: Review and Herald, 2003.

. Present Truth in the Real World. Boise, ID: Pacific Press, 1993.

Peel, William Carr, and Walt Larimore. Going Public with Your Faith. Grand Rapids, MI: Zondervan, 2003.

Petersen, Jim. Evangelism as a Lifestyle. Colorado Springs, CO: Navpress, 1980.

Phillips, Donald T. The Founding Fathers on Leadership. New York: Warner, 1997.

Phillips, Judy, and Michael Phillips. Best Friends for Life. Minneapolis: Bethany, 1997.

Pippert, Rebecca Manley. Out of the Saltshaker. Downers Grove, IL: InterVarsity, 1999.

Pollard, Leslie N. Embracing Diversity. Hagerstown, MD: Review and Herald, 2000.

Pollard, Nick. Evangelism Made Slightly Less Difficult. Downers Grove, IL: InterVarsity, 1997.

Posterski, Don. Why Am I Afraid to Tell You I'm a Christian? Downers Grove, IL: InterVarsity, 1983.

Pratney, Winkle. A Handbook for Followers of Jesus. Minneapolis: Bethany, 1977.

Prince, Matthew. Winning Through Caring. Grand Rapids, MI: Baker, 1981.

Proctor, Samuel D., and Gardner C. Taylor. We Have This Ministry. Valley Forge, PA: Judson, 1996.

Rabey, Steve, and Lois Rabey. Side by Side: A Handbook. Colorado Springs, CO: Cook Communications Ministries, 2000.

Rainer, Thom S. Breakout Churches. Grand Rapids, MI: Zondervan, 2005. . High Expectations. Nashville: Broadman and Holman, 1999. . Surprising Insights from the Unchurched. Grand Rapids, MI: Baker, 2001.

Rath, Tom. Vital Friends. New York: Gallup, 2006. 
Ratzinger, Joseph Cardinal. Many Religions-One Covenant. San Francisco: Ignatius, 1998.

Raunikar, Don. Choosing God's Best. Sisters, OR: Multnomah, 1998.

Reeve, Pamela. Relationships, What It Takes to Be a Friend. Sisters, OR: Multnomah, 1997.

Rendle, Gil, and Susan Beaumont. When Moses Meets Aaron. Herndon, VA: The Alban Institute, 2007.

Rendtorff, Rolf. The Covenant Formula. Edinburgh: T and T Clark, 1998.

Richardson, Rick. Evangelism Outside the Box. Downers Grove, IL: InterVarsity, 2000.

Richardson, Willie. Reclaiming the Urban Family. Grand Rapids, MI: Zondervan, 1996.

Richards, Larry. Every Covenant and Promise in the Bible. Nashville: Thomas Nelson, 1998.

Robbins, John M. You Can Win Souls. Wheaton, MD: by the author, 1998.

Robinson, Darrell W. People Sharing Jesus. Nashville: Thomas Nelson, 1995.

Robnett, Timothy, and Allen H. Quist. The Spirit Driven Church. Colorado Springs, CO: Victor, 2006.

Rogers, Cleon L. Jr., and Cleon L. Rogers III. The New Linguistic and Exegetical Key to the Greek New Testament. Grand Rapids, MI: Zondervan, 1998.

Roper, David H. The New Covenant in the Old Testament. Waco, TX: Word, 1976.

Roth, Wolfgang, and Rosemary Radford Ruether. The Liberating Bond. New York: Friendship, 1978.

Roy, Ruthven. A Challenge to the Remnant! Frederick, MD: NDM Books, 2002.

Rubin, Kenneth H. The Friendship Factor. New York: Viking, 2002.

Sahlin, Monte. Friendship Evangelism Seminar. Siloam Springs, AK: Concerned Communications, 1988.

. Sharing Our Faith with Friends Without Losing Either. Hagerstown, MD: Review and Herald, 1990. 
Samaan, Philip G. Christ's Way of Making Disciples. Hagerstown, MD: Review and Herald, 1999.

. Christ's Way of Reaching People. Hagerstown, MD: Review and Herald, 1990.

. Christ's Way of Spiritual Growth. Hagerstown, MD: Review and Herald, 1995.

Samuel, Emma. Friends: What Would I Do Without Them? Washington, DC: Emida International, 1999.

Sanna, Ellyn. Friends. Uhrichsville, OH: Barbour, 1999.

Sawyer, Nanette. Hospitality - The Sacred Art. Woodstock, VT: SkyLight Paths, 2008.

Scazzero, Peter. The Healthy Church. Grand Rapids, MI: Zondervan, 2003.

Schaller, Lyle E. The Very Large Church. Nashville: Abingdon, 2000.

Schwarz, Christian A. The ABC's of Natural Church Development. Carol Stream, IL: ChurchSmart Resources, 1998.

. Natural Church Development. Carol Stream, IL: ChurchSmart Resources, 1996.

Schwarz, Christian A., and Christoph Schalk. Implementation Guide to Natural Church Development. St. Charles, IL: ChurchSmart Resources, 1998.

Sellon, Mary K., and Daniel P. Smith. Practicing Right Relationship. Herndon, VA: The Alban Institute, 2005.

Seventh-day Adventist Encyclopedia, 1976 ed. S.v. "White, Ellen Gould Harmon."

Sheldon, Charles M. His Brother's Keeper. Nashville: Thomas Nelson, 1999. . In His Steps. Uhrichsville, OH: Barbour, 1985.

Shelley, Marshall. Well-Intentioned Dragons. Waco, TX: Word, 1985.

Sider, Ronald J., Philip N. Olson, and Heidi Rolland Unruh. Churches That Make a Difference. Grand Rapids, MI: Baker, 2002.

Simpson, Michael L. Permission Evangelism. Colorado Springs, CO: NexGen, 2003.

Sims, Bennett J. Servanthood. Boston: Cowley, 1997. 
Sjogren, Steve. Conspiracy of Kindness. Ann Arbor, MI: Vine, 1993.

Sjogren, Steve, Dave Ping, and Doug Pollock. Irresistible Evangelism. Loveland, CO: Group, 2004.

Sjogren, Steve, and Rob Lewin. Community of Kindness. Ventura, CA: Regal, 2003.

Slater, Michael. Stretcher Bearers. Ventura, CA: Regal, 1985.

Smalley, Gary. The DNA of Relationships. Wheaton, IL: Tyndale, 2004. . Your Relationship with God. Carol Stream, IL: Tyndale, 2006.

Smith, Fred, Sr. Leading with Integrity. Minneapolis: Bethany, 1999.

Smith, Jack R., and Jennifer Kennedy Dean. Witnessing Through Your Relationships. Nashville: LifeWay, 1994.

Solomon, Muriel. Working with Difficult People. Paramus, NJ: Prentice Hall, 1990.

Solomon, Robert C., and Fernando Flores. Building Trust in Business, Politics, Relationships, and Life. New York: Oxford, 2001.

Spurgeon, Charles Haddon. The Soul Winner. Grand Rapids, MI: Eerdmans, 1963.

Staples, Russell L. Community of Faith. Hagerstown, MD: Review and Herald, 1999.

Stanley, Andy, and Bill Willits. Creating Community. Sisters, OR: Multnomah, 2004.

Staub, Robert E. The Heart of Leadership. Provo, UT: Executive Excellence, 1996.

Stebbins, Tom. Friendship Evangelism by the Book. Camp Hill, PA: Christian, 1995.

Stefoff, Rebecca. Friendship and Love. New York: Chelsea, 1989.

Steinbron, Melvin J. Can the Pastor Do It Alone? Ventura, CA: Regal, 1987. . The Lay Driven Church. Ventura, CA: Regal, 1997.

Stevens, R. Paul. Liberating the Laity. Downers Grove, IL: InterVarsity, 1985. . The Other Six Days. Grand Rapids, MI: Eerdmans, 1999.

Stevens, R. Paul, and Phil Collins. The Equipping Pastor. New York: The Alban Institute, 1993. 
Stevens, Tim, and Tony Morgan. Simply Strategic Stuff.Loveland, CO: Group, 2004.

Stewart, Carlyle Fielding. African American Church Growth. Nashville: Abingdon, 1994.

Stone, Bryan. Evangelism after Christendom. Grand Rapids, MI: Brazos, 2007.

Stone, J. David, and Larry Keefauver. Friend to Friend. Minneapolis: Educational Media, 1993.

Stott, John. The Living Church. Downers Grove, IL: InterVarsity, 2007.

Stowell, Joseph M. Shepherding the Church. Chicago: Moody, 1997.

Strobel, Charles. Inside the Mind of Unchurched Henry and Mary: How to Reach Friends and Family Who Avoid God and the Church. Grand Rapids, MI: Zondervan, 1993.

Sullivan, Bill M. Ten Steps to Breaking the 200 Barrier. Kansas City, MO: Beacon Hill, 1988.

Sweet, Leonard. The Gospel According to Starbucks. Colorado Springs, CO: Waterbrook, 2007. 2004.

. Out of the Question ... into the Mystery. Colorado Springs, CO: Waterbrook,

Swindoll, Charles. Hand Me Another Brick. Nashville: Word, 1998.

Tabb, Mark. Mission of Oz. Chicago: Moody, 2004.

Terry, John Mark. Church Evangelism. Nashville: Broadman and Holman, 1997.

Thompson, George B. How to Get Along with Your Church. Cleveland, OH: The Pilgrim Press, 2001.

Tingley, Judith C. The Power of Indirect Influence. New York: AMACOM, 2000.

Toler, Stan. $A B C$ 's of Evangelism. Atlanta: Injoy, 1995.

. The People Principle. Kansas City, MO: Beacon Hill, 1997.

Toler, Stan, and Larry Gilbert. The Pastor's Playbook. Kansas City, MO: Beacon Hill, 2000.

Toler, Stan and Louie E. Bustle. Each One Win One. Kansas City, MO: Beacon Hill, 2006. 
Torrey, R. A. How to Witness to Anyone. Springdale, PA: Whitaker, 1986.

Towns, Elmer. Winning the Winnable. Lynchburg, VA: Church Growth Institute, 1989.

Townsend, John. Loving People. Nashville: Thomas Nelson, 2007.

Townsend, Patrick L., and Joan E. Gebhardt. Five-Star Leadership. New York: John Wiley and Sons, 1997.

Trueblood, Roy W., and Jackie B. Trueblood. Partners in Ministry. Nashville: Abingdon, 1999.

Trumbull, H. Clay. The Blood Covenant. Kirkwood, MO: Impact Christian, 1975.

Turner, William L. Anytime, Anywhere. Valley Forge, PA: Judson, 1997.

Vanderhorst, Kwame Ronnie. “Call Me a Playa' Hater!” Washington, DC: Hotep, 2001.

Van Fleet, James K. Power with People. West Nyack, NY: Parker, 1970.

Van Pelt, Nancy. Creative Hospitality. Hagerstown, MD: Review and Herald, 1995.

Vigeveno, H. S. The Touch of Jesus. Grand Rapids, MI: Discovery, 1997.

Vines, Jerry. Spirit Life. Nashville: Broadman and Holman, 1998.

Wadell, Paul J. Becoming Friends. Grand Rapids, MI: Baker, 2002.

Wagner, C. Peter. The Church in the Workplace. Ventura, CA: Regal, 2006. . The Healthy Church. Ventura, CA: Regal, 1996.

Wagner, E. Glenn. Escape from Church, Inc. Grand Rapids, MI: Zondervan, 1999.

Waitley, Denis, and Boyd Matheson. Attitude: Your Internal Compass. Aurora, IL: Successories, 1997.

Walter, Elden A. New Testament Witnessing. Richardson, TX: by the author, 1971.

Walther, George R. Phone Power. New York: Berkley, 1986.

Walton, John H. Covenant. Grand Rapids, MI: Zondervan, 1994.

Wardle, Terry. One to One: A Practical Guide to Friendship Evangelism. Camp Hill, PA: Christian, 1989. 
Watson, David. Called and Committed: World-Changing Discipleship. Wheaton, IL: Shaw, 1982.

Webber, Robert E. Ancient-Future Evangelism. Grand Rapids, MI: Baker, 2003.

Webster, Doug. The Easy Yoke. Colorado Springs, CO: Navpress, 1995.

Webster, Douglas D. The Discipline of Surrender. Downers Grove, IL: InterVarsity, 2001.

Weidemann, Valerie, and James C. Galvin. Life Application Bible Studies: Friendship. Wheaton, IL: Tyndale, 1996.

Wheeler, Gerald, and Bill Cleveland. Getting Ready to Meet Jesus. Hagerstown, MD: Review and Herald, 1998.

White, Ellen G. Acts of the Apostles. Mountain View, CA: Pacific Press, 1949. . Christian Service. Mountain View, CA: Pacific Press, 1947. . Christ's Object Lessons. Washington, DC: Review and Herald, 1900. . Desire of Ages. Mountain View, CA: Pacific Press, 1947. . Education. Mountain View, CA: Pacific Press, 1952. . Evangelism. Washington, DC: Review and Herald, 1946. . Gospel Workers. Washington, DC: Review and Herald, 1944. . Living the Life of Enoch. Brushton, NY: Teach, 1996. . Medical Ministry. Mountain View, CA: Pacific Press, 1963. . The Ministry of Healing. Mountain View, CA: Pacific Press, 1942. . My Life Today. Hagerstown, MD: Review and Herald, 1980. . Selected Messages. Vol. 1. Washington, DC: Review and Herald, 1958. . Steps to Christ. Mountain View, CA: Pacific Press, 1908. 1948. 
. Testimonies to Ministers and Gospel Workers. Mountain View, CA: Pacific Press, 1923. 1942.

. Welfare Ministry. Washington, DC: Review and Herald, 1952.

White, Robert A. How to Win a Soul. Nashville: Southern Publishing, 1971.

Wickwire, Jeff. Friendships. Grand Rapids, MI: Chosen, 2007.

Wiggins, Kembleton S. Soul Winning Made Easier. Mountain View, CA: Pacific Press, 1975.

Wilkins, Scott G. Reach. Grand Rapids, MI: Baker, 2005.

Wilkinson, Bruce H. Experiencing Spiritual Breakthroughs. Sisters, OR: Multnomah, 1999.

Willard, Dallas. The Great Omission. San Francisco: Harper, 2006.

Willingham, Russell. Relational Masks. Downers Grove, IL: InterVarsity, 2004.

Williams, Robert C. "Improving the Assimilation of New Members in Small Adventist Churches in Central Pennsylvania." D. Min. dissertation, Andrews University, 1996.

Willis, Avery T. Master Life Developing a Rich Personal Relationship with the Master. Nashville: Broadman and Holman, 1998.

Wilson, Earl, Paul Sandy, Virginia Friesen, and Larry and Nancy Paulson. Restoring the Fallen. Downers Grove, IL: InterVarsity, 1997.

Wilson, Marlene. How to Mobilize Church Volunteers. Minneapolis: Augsburg, 1983.

Worley, Robert C. Dry Bones Breathe! Chicago: The Center For the Study of Church Organizational Behavior, 1978.

Wuellner, Flora Slosson. Feed My Shepherds. Nashville: Upper Room, 1998.

Yount, William R., and Mike Barnett. Called to Reach. Nashville: Broadman and Holman, 2007.

Zackrison, James. Power to Witness. Nampa, ID: Pacific Press, 1993. 
Zaragoza, Edward C. No Longer Servants, but Friends. Nashville: Abingson, 1999.

Ziglar, Zig. Top Performance. New York: Berkley, 1987. 
VITA

Pastor Marcellus T. Robinson

(Ordained 1988)

Academic Achievements:

$\begin{array}{lll}\text { Degree } & \underline{\text { Institution }} & \text { Year } \\ \text { Bachelor of Arts } & \text { Andrews University } & 1981 \\ \text { Masters of Divinity } & \text { Andrews University } & 1984 \\ \text { Doctor of Ministry } & \text { Andrews University } & 2008\end{array}$

Churches Pastored:

\begin{tabular}{lll} 
Pastorates & Conference & $\underline{\text { Year }}$ \\
\cline { 2 - 2 } & Lake Region & 1984 \\
Evanston, IL & Lake Region & 1986 \\
Waukegan, IL & Lake Region & 1986 \\
Inkster, MI & Lake Region & 1988 \\
Bladensburg, MD & Allegheny East & 1993
\end{tabular}

Present Job Title:

Senior Pastor, Emmanuel-Brinklow SDA Church in Ashton, Maryland, Allegheny East Conference 